\title{
EUTROPHICATION POTENTIAL OF PAYETTE LAKE, IDAHO
}

BYPAUL F. WOODS

\section{U.S. GEOLOGICAL SURVEY}

Water-Resources Investigations Report 97-4145

Prepared in cooperation with the IDAHO DIVISION OF ENVIRONMENTAL QUALITY

Boise, Idaho 1997 


\title{
U.S. DEPARTMENT OF THE INTERIOR BRUCE BABBITT, Secretary
}

\author{
U.S. GEOLOGICAL SURVEY \\ Gordon P. Eaton, Director
}

The use of firm, trade, and brand names in this report is for identification purposes only and does not constitute endorsement by the U.S. Geological Survey.

For additional information write to:

Copies of this report can be purchased from:

District Chief

U.S. Geological Survey

230 Collins Road

Boise, ID 83702-4520
U.S. Geological Survey

Information Services

Box 25286

Federal Center

Denver, CO 80225 


\section{CONTENTS}

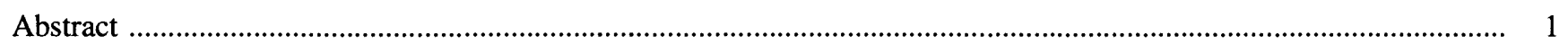

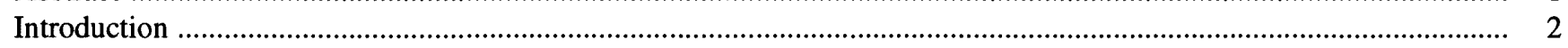

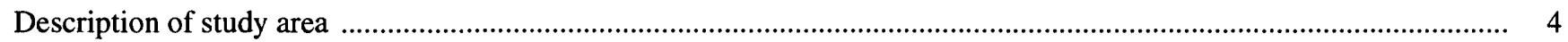

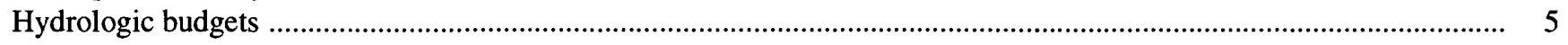

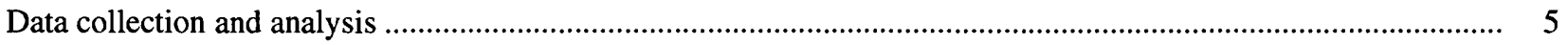

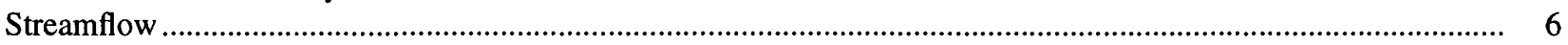

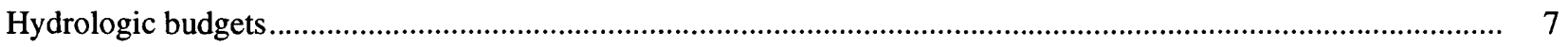

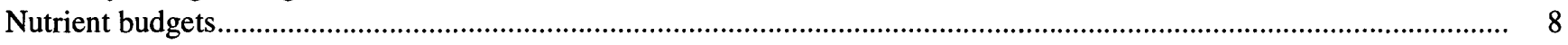

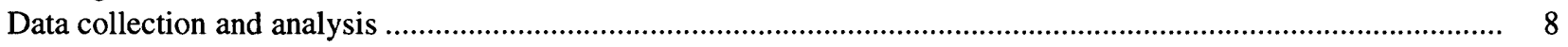

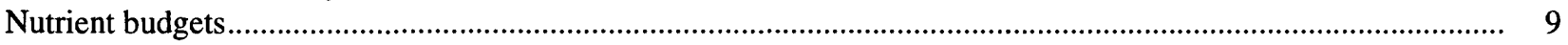

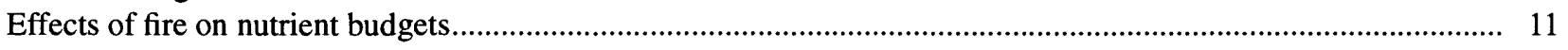

Limnology.

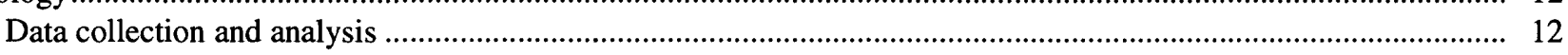

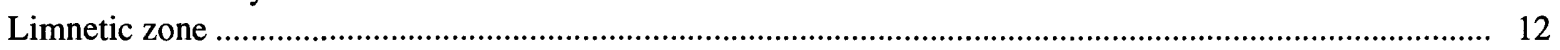

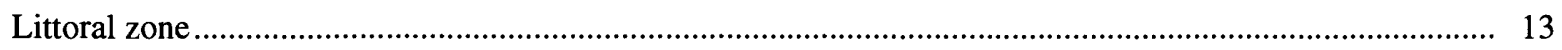

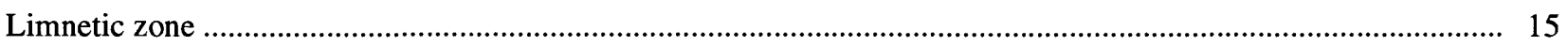

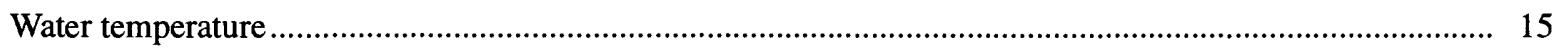

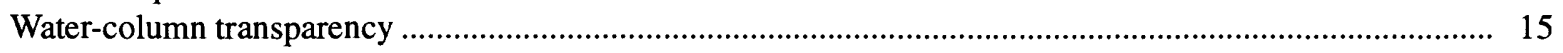

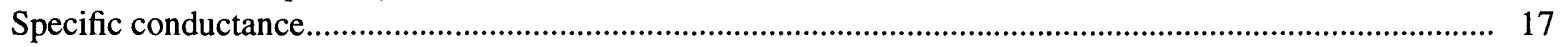

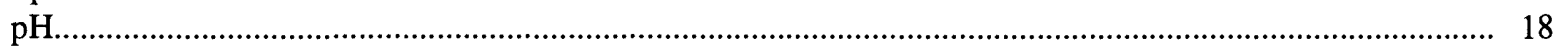

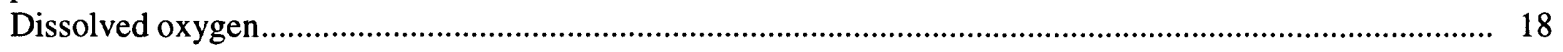

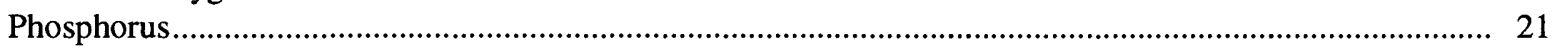

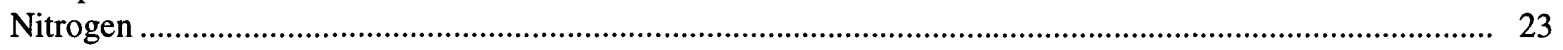

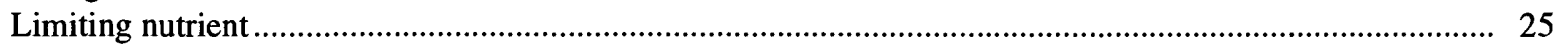

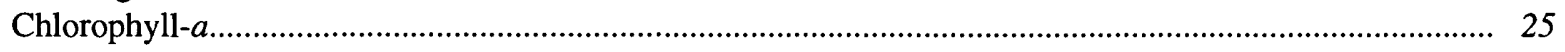

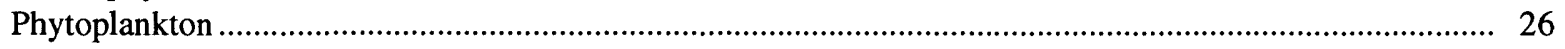

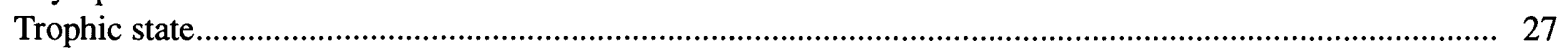

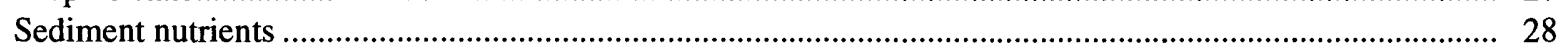

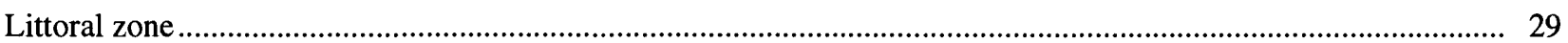

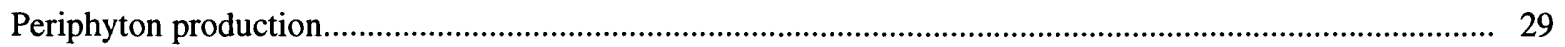

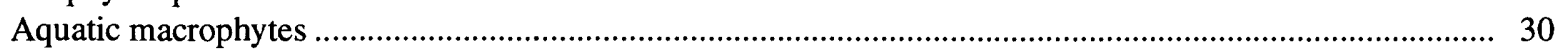

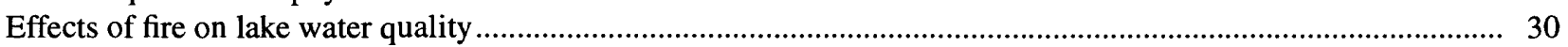

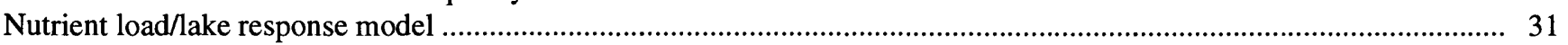

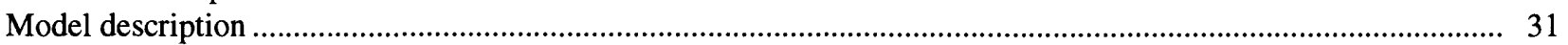

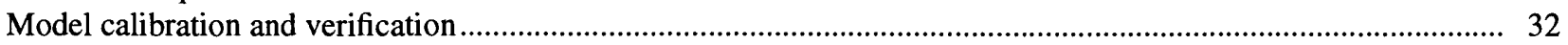

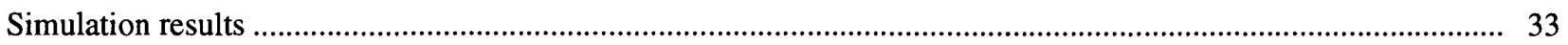

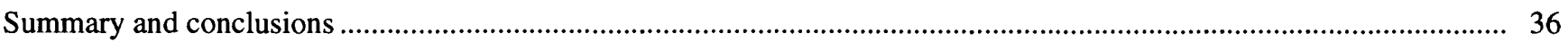

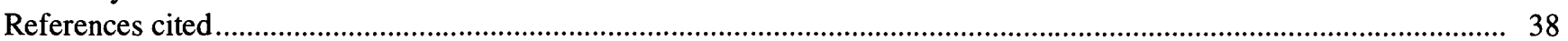

\section{FIGURES}

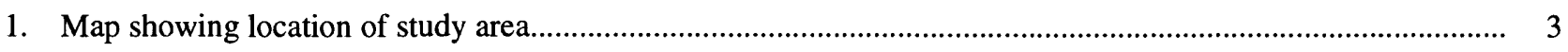

2. Graph showing relation of depth to lake surface area and volume for Payette Lake........................................ 6

3. Map showing locations of limnetic and littoral sampling stations and model segments, and bathymetry of Payette Lake

4-12. Graphs showing:

4. Lines of equal temperature, in degrees Celsius, at stations 1-4 during selected months of 1995-96,

Payette Lake....

5. Depths of euphotic zone and secchi-disc transparency at stations 1-4 during 1995-96, Payette Lake 
6. Lines of equal dissolved-oxygen concentration, in milligrams per liter, at stations 1-4 during selected months of 1995-96, Payette Lake...

7. Lines of equal dissolved oxygen, as percent saturation, at stations 1-4 during selected months of 1995-96, Payette Lake...

8. Concentrations of total phosphorus and dissolved orthophosphorus in the euphotic zone and lower hypolimnion at stations 1-4 during 1995-96, Payette Lake

9. Concentrations of total nitrogen, dissolved inorganic nitrogen, and dissolved ammonia in the euphotic zone and lower hypolimnion at stations 1-4 during 1995-96, Payette Lake.

10. Ratios of dissolved inorganic nitrogen to dissolved orthophosphorus at stations 1-4 during 1995-96, Payette Lake.

11. Chlorophyll- $a$ concentrations at stations 1-4 during 1995-96, Payette Lake 26

12. Phytoplankton biovolume at stations 1-4 during 1995-96, Payette Lake

\section{TABLES}

1. Annual coefficients for unit runoff and nutrient export for three gaged inflow stations and one gaged outflow station, 1995-96, Payette Lake

2. Hydrologic budget and errors associated with each budget component, 1995-96, Payette Lake

3. Total phosphorus budget and errors associated with each budget component, 1995-96, Payette Lake ....................

4. Total nitrogen budget and errors associated with each budget component, 1995-96, Payette Lake .........................

5. Loads of nitrogen and phosphorus for water years 1995 and 1996 at North Fork Payette River below Fisher Creek (13238322) and North Fork Payette River at McCall (13239000)

6. Medians and ranges of secchi-disc transparency and euphotic-zone depth at four limnetic stations, 1995-96, Payette Lake.

7. Medians of total phosphorus and dissolved orthophosphorus from the euphotic zone and lower hypolimnion at four limnetic stations, 1995-96, Payette Lake

8. Medians of total nitrogen and dissolved inorganic nitrogen from the euphotic zone and lower hypolimnion at four limnetic stations, 1995-96, Payette Lake

9. Medians and ranges of ratios of dissolved inorganic nitrogen to dissolved orthophosphorus from the euphotic zone at four limnetic stations, 1995-96, Payette Lake

10. Medians and ranges of chlorophyll- $a$ concentrations and phytoplankton biovolumes from the euphotic zone at four limnetic stations, 1995-96, Payette Lake

11. Phytoplankton taxa at four limnetic stations, 1995-96, Payette Lake

12. Trophic state of Payette Lake during 1995-96 based on annual geometric mean values for four limnological variables

13. Concentrations of total phosphorus and total nitrogen in lakebed sediments at four limnetic stations, July 1996, Payette Lake

14. Periphyton production, as chlorophyll-a, at 19 littoral stations, July-August 1996, Payette Lake

15. Aquatic macrophyte taxa at 19 littoral stations, July 1996, Payette Lake

16. Characteristics of the four segments of Payette Lake modeled by BATHTUB

17. Results of model calibration with 1996 data and model verification with 1995 data, Payette Lake

18. Presence or absence of overlap in standard errors for observed and estimated values of five limnological variables for calibration and verification model runs, Payette Lake

19. Simulation 1: Limnological response to estimated phosphorus and nitrogen loads delivered to Payette Lake prior to 1994 forest fires

20. Simulation 2: Limnological response to increased phosphorus and nitrogen loads caused by potential forest fires in watershed areas not burned during the 1994 forest fires.

21. Simulation 3: Limnological response to 20-percent reduction in phosphorus and nitrogen loads from developed shoreline areas; comparison is to simulated response to pre-1994 forest fires (Simulation 1, table 19).....

22. Simulation 4: Limnological response to 20-percent reduction in phosphorus and nitrogen loads from watershed areas subjected to timber-harvest activities; comparison is to simulated response to pre-1994 forest fires (Simulation 1, table 19).

23. Simulation 5: Limnological response to 20-percent reduction in phosphorus and nitrogen loads from developed shoreline areas and watershed areas subjected to timber-harvest activities; comparison is to simulated response to pre-1994 forest fires (Simulation 1, table 19) 
CONVERSION FACTORS, VERTICAL DATUM, AND ABBREVIATED WATER-QUALITY UNITS

\begin{tabular}{rcl}
\hline Multiply & By & To obtain \\
centimeter $\left(\mathrm{cm}^{3}\right)$ & 0.3937 & inch \\
cubic hectometer $\left(\mathrm{hm}^{3}\right)$ & 810.7 & acre-foot \\
cubic kilometer $\left(\mathrm{km}^{3}\right)$ & 0.2399 & acre-foot per acre \\
cubic hectometer per square kilometer $\left(\mathrm{hm}^{3} / \mathrm{km}^{2}\right)$ & 3.281 & cubic mile \\
hectare $(\mathrm{ha})$ & 2.471 & cubic foot per second \\
kilogram $(\mathrm{kg})$ & 2.205 & acre \\
kilogram per hectare $(\mathrm{kg} / \mathrm{ha})$ & 0.8922 & pound, avoirdupois \\
kilogram per square kilometer $\left(\mathrm{kg} / \mathrm{km}^{2}\right)$ & 2,000 & pound per acre \\
kilometer $(\mathrm{km})$ & 0.6214 & ton per acre \\
liter $(\mathrm{L})$ & 0.2642 & mile \\
meter $(\mathrm{m})$ & 3.281 & gallon \\
microgram $(\mu \mathrm{g})$ & 0.000000002205 & foot \\
micrometer $(\mu \mathrm{m})$ & 0.00003937 & pound \\
milligram $(\mathrm{mg})$ & 0.000002205 & pound \\
milligram per kilogram $(\mathrm{mg} / \mathrm{kg})$ & 0.002001 & pound per ton \\
milliliter $(\mathrm{mL})$ & 0.03381 & ounce \\
millimeter $(\mathrm{mm})$ & 0.03937 & inch \\
square kilometer $\left.(\mathrm{km})^{2}\right)$ & 0.3861 & square mile \\
square meter $\left(\mathrm{m}^{2}\right)$ & 10.76 & square foot \\
\hline & &
\end{tabular}

To convert ${ }^{\circ} \mathrm{C}$ (degrees Celsius) to ${ }^{\circ} \mathrm{F}$ (degrees Fahrenheit), use the following equation:

$$
{ }^{\circ} \mathrm{F}=(1.8)\left({ }^{\circ} \mathrm{C}\right)+32
$$

Sea level: In this report, "sea level" refers to the National Geodetic Vertical Datum of 1929—a geodetic datum derived from a general adjustment of the first-order level nets of the United States and Canada, formerly called Sea Level Datum of 1929.

\section{Abbreviated water-quality units:}

cells/mL cells per milliliter

$\mu \mathrm{m} 3 / \mathrm{mL} \quad$ cubic micrometer per milliliter

$\mathrm{E} \quad$ Einstein

$\mathrm{E} / \mathrm{m}^{2} \quad$ Einstein per square meter

$\mu \mathrm{g} / \mathrm{L} \quad$ microgram per liter

$\mu \mathrm{S} / \mathrm{cm} \quad$ microsiemens per centimeter at $25^{\circ} \mathrm{C}$

$\mathrm{mg} / \mathrm{L} \quad$ milligram per liter

$\left(\mathrm{mg} / \mathrm{m}^{2}\right) / \mathrm{d} \quad$ milligram per square meter per day

$\left(\mathrm{mg} / \mathrm{m}^{3}\right) / \mathrm{d} \quad$ milligram per cubic meter per day

$\mathrm{mg} / \mathrm{m}^{2} \quad$ milligram per square meter

$\left(\mathrm{mg} / \mathrm{m}^{2}\right) / \mathrm{E}$ milligram per square meter per Einstein 


\title{
EUTROPHICATION POTENTIAL OF PAYETTE LAKE, IDAHO
}

\author{
By Paul F. Woods
}

\section{ABSTRACT}

Payette Lake was studied during water years 1995-96 to determine the 20.5-square-kilometer lake's assimilative capacity for nutrients and, thus, its eutrophication potential. The study included quantification of hydrologic and nutrient budgets, characterization of water quality in the limnetic and littoral zones, development of an empirical nutrient load/lake response model, and estimation of the limnological effects of a large-scale forest fire in the lake's 373-square-kilometer watershed during the autumn of 1994.

Streamflow from the North Fork Payette River, the lake's primary tributary, delivered about 73 percent of the lake's inflow over the 2 years. Outflow from the lake, measured since 1908, was 128 and 148 percent of the long-term average in 1995 and 1996, respectively. The larger volumes of outflow reduced the long-term average waterresidence time of 2.35 years to 1.84 and 1.42 years for 1995 and 1996, respectively. The lake retained 54 percent of its 1995-96 influent load of nitrogen and 79 percent of its influent load of phosphorus. The North Fork Payette River contributed an average of 69.4 percent of the lake's nitrogen load and 28.2 percent of its phosphorus load. The 1994 forest fires substantially increased the loads of nitrogen and phosphorus delivered to the lake; however, only nitrogen concentrations were noticeably increased in the lake.

Payette Lake was classified as oligotrophic on the basis of annual geometric mean concentrations, in micrograms per liter, of total phosphorus (4.7), total nitrogen (225), and chlorophyll- $a$ (1.3) during 1995-96. Secchi-disc transparencies ranged from 2.3 to 8.0 meters, indicative of mesotrophic conditions. Median ratios of dissolved inorganic nitrogen to dissolved orthophosphorus ranged from 38 to 254 , thereby indicating phosphorus limitation of phytoplankton growth. Phytoplankton populations were taxonomically dominated by diatoms; blue-green algae were rare. One diatom, Tabellaria fenestrata, contributed 52 percent of the biovolume. Within the littoral zone, median periphyton production, normalized to photosynthetically active radiation input, ranged from 0.0007 to 0.02 milligrams of chlorophyll- $a$ per square meter per Einstein, a difference of 28.6 times. Multiple linear regression analysis failed to detect any significant relation between periphyton production and various indices of nearshore development. Nine genera of aquatic macrophytes were identified, including Eurasian milfoil (Myriophyllum spicatum var. spicatum), which is considered a nuisance aquatic plant.

Despite its oligotrophy, Payette Lake had substantial dissolved-oxygen deficits in 1995-96, which led to 4-month periods of anoxia in the nearbottom waters of its southwest basin. The hypolimnetic dissolved-oxygen deficit was much larger than that predicted by the nutrient load/lake response model. The southwest basin's propensity for developing anoxia was related to the lengthy water-residence time and incomplete water-column circulation and reaeration during the spring and autumn, coupled with a long-term accumulation of oxygendemanding organic matter produced within the lake or delivered by its watershed. 


\section{INTRODUCTION}

Payette Lake is situated in Valley County, one of Idaho's rural, mountainous areas with a thriving tourism/recreation industry (fig. 1). Prior to the arrival of Euro-American hunters in the 1830's, the area had been inhabited by Native Americans for thousands of years. The discovery of gold in 1862 in the upper drainage of Payette Lake prompted a major influx of miners to the area. The townsite of McCall was established on Payette Lake's southern shore in the late 1880's. The area became much more accessible in 1914 when a railroad and roads were extended to McCall, which was fast becoming an important tourist destination for summer and winter recreation. In 1920, the Idaho State Land Board began leasing vacation homesites around Payette Lake. Increasing recreational demands led to the establishment of Brundage Mountain Ski Area and Ponderosa State Park, both near McCall, in the 1960's. By 1995, McCall's population had grown to 2,600 and is projected to increase about 25 percent over the next decade (Valley County, 1995).

In addition to human activities around its shoreline, Payette Lake's watershed has been subjected to timber harvesting and associated road building, recreational use, grazing, and very limited mining. Timber harvesting began around 1900, but large-scale commercial harvesting did not begin until the early 1950 's. Since then, the area harvested per decade has risen from 276 ha during the 1950's to 2,420 ha during the 1990's (Payette Lake Technical Advisory Committee, written commun., 1997). Most of the $412 \mathrm{~km}$ of roads in the watershed are unpaved and used for timber-harvesting activities and recreation. A wide variety of recreational uses attract about 65,000 visitors into the watershed annually, during the summer and fall months (U.S. Forest Service, 1995a). Nomadic sheep grazing began around 1880 ; during $1912-18$, about 30,000 sheep were being grazed under the first grazing permits (U.S. Forest Service, 1995b). Grazing allotments in the 1990's are for about 4,600 sheep.

One of the earliest references to Payette Lake's water quality was made in the 1890's in a report to the U.S. Fish Commission, which noted the presence of sockeye salmon (Oncorhynchus nerka) and watercolumn transparency as much as $9 \mathrm{~m}$ (U.S. Forest Service, 1995b). By the late 1960's, concern for bacterial contamination prompted the Idaho Department of Health (IDH) to conduct studies on the effects of sewage disposal from nearshore dwellings around Payette
Lake. A bacteriological survey conducted during 1964 documented many unsatisfactory sewage-disposal systems in nearshore areas (Idaho Department of Health, 1970). A second, more intensive, study was conducted during 1967-69 to determine the extent of bacterial contamination, describe chemical conditions, and determine the general degree of eutrophication. That study (Idaho Department of Health, 1970) classified the lake as oligotrophic, on the basis of chemical and biological variables, and noted obvious bacterial contamination in some nearshore areas. On the basis of these two studies, the IDH recommended that a sewage-collection system be installed around Payette Lake to protect its oligotrophic condition and to reduce the human health risks associated with bacterial contamination.

The U.S. Environmental Protection Agency (EPA) studied Payette Lake in 1975 as part of the National Eutrophication Survey (U.S. Environmental Protection Agency, 1977). Water-quality analyses were indicative of excellent conditions and a trophic state of early mesotrophic. This study was the first to estimate the lake's annual nutrient budget. Of the $4,100 \mathrm{~kg}$ of total phosphorus estimated to enter the lake during a year of average inflow, about 68 percent was from the North Fork Payette River and about 0.5 percent was from nearshore sewage-disposal systems. Of the $198,000 \mathrm{~kg}$ of total nitrogen, 65.6 percent was from the North Fork Payette River and 0.3 percent was from nearshore sewagedisposal systems.

A comprehensive limnological assessment of Payette Lake was conducted during 1981-82 in response to concerns over possible water-quality deterioration caused by lakeshore and watershed development, and to monitor the water-quality effects of construction of a gravity sewer line along the lake's shoreline (Falter and Mitchell, 1981; Falter, 1984). Concentrations of nutrients and chlorophyll- $a$ were low in the open areas of the lake, but significant inputs of nutrients and bacteria were measured in nearshore areas, especially in the west and southeast basins. This was the first study to measure dissolved-oxygen concentrations throughout the water column in the lake's deepest basins. In September, dissolved-oxygen concentrations of about $4 \mathrm{mg} / \mathrm{L}$ below the $60-\mathrm{m}$ depth in the west basin were indicative of a substantial dissolved-oxygen deficit. This study estimated the lake's annual nutrient budget for 1982; however, it was not directly comparable to the 1975 nutrient budget because inflow during 1982 was 145 percent of the long-term average. Of the $14,000 \mathrm{~kg}$ of total phosphorus input to the lake in 1982, 71.4 percent was from 


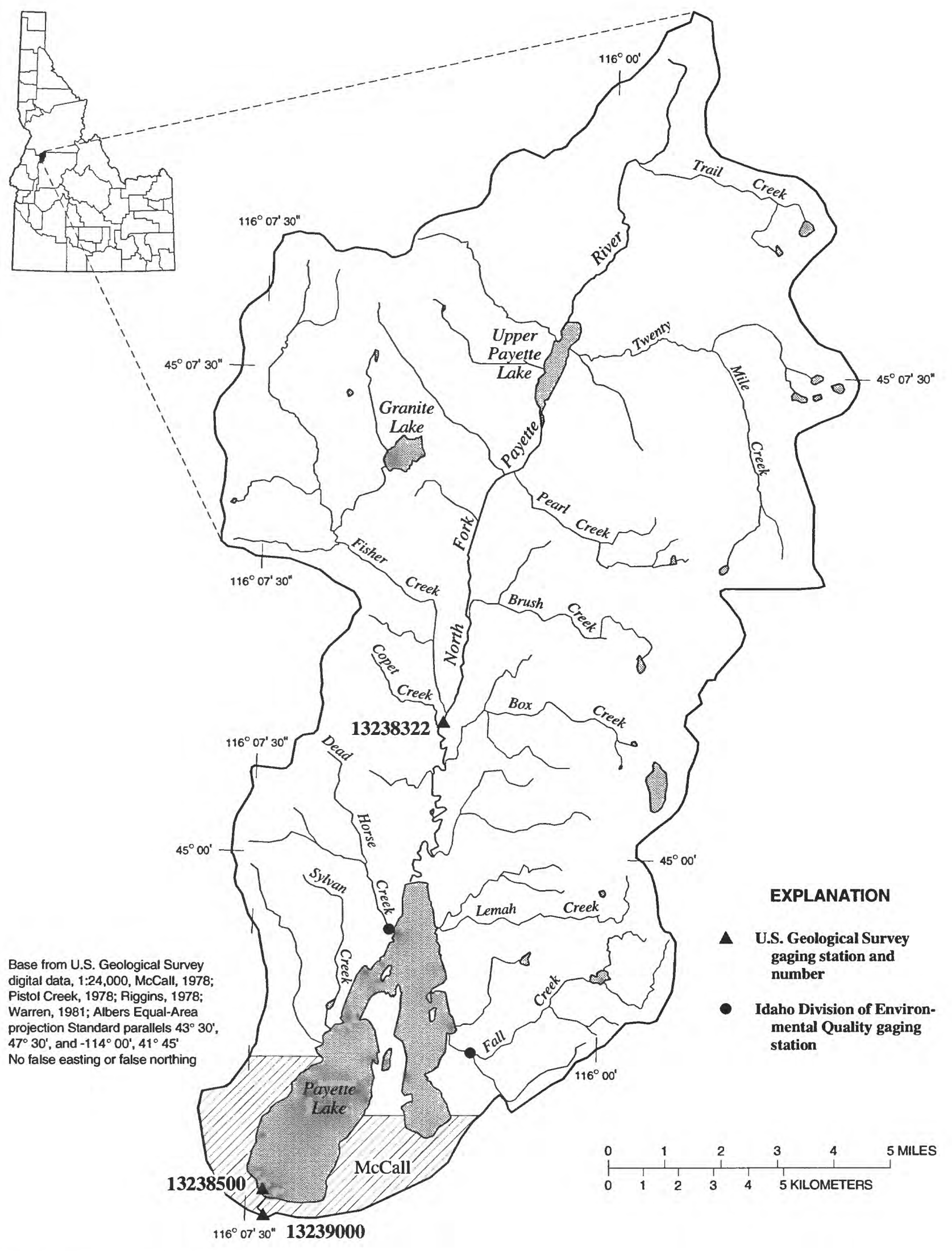

Figure 1. Location of study area. 
the North Fork Payette River and 1.7 percent was from nearshore sewage-disposal systems. About $87,300 \mathrm{~kg}$ of total nitrogen entered the lake in $1982 ; 42.7$ percent was from the North Fork Payette River and 2 percent was from nearshore sewage-disposal systems. On the basis of the lake's nutrient loadings and dissolved-oxygen deficit, the lake's trophic state was classified as mesotrophic.

Over the past decade, limnological data have been collected sporadically at Payette Lake by State agencies such as the Idaho Department of Fish and Game (IDFG) and Idaho Division of Environmental Quality (IDEQ); however, the scope of these efforts has been more limited than that of the 1975 and 1981-82 studies. Of interest are the dissolved-oxygen profiles collected by IDEQ on six occasions during 1992-93. The lowest dissolvedoxygen concentration, $2.8 \mathrm{mg} / \mathrm{L}$, was measured at a depth of $71 \mathrm{~m}$ in the lake's west basin in late July 1992 (D. Worth, Idaho Division of Environmental Quality, written commun., September 1995).

These prior water-quality studies revealed that Payette Lake has undergone some degree of eutrophication on the basis of symptomatic evidence such as substantial dissolved-oxygen deficits and nutrient loadings. Although a sewage-collection system was completed in the mid-1980's, the reduction in the lake's overall nutrient budget was probably less than a few percent. The continuation of substantial dissolved-oxygen deficits into the early 1990's is evidence the lake is still undergoing eutrophication. Fishery data collected since the early 1980 's also indicate that the lake may be more biologically productive than in the past. In 1980 and 1988, the biomass of wild kokanee salmon was 0.18 and 0.24 $\mathrm{kg} / \mathrm{ha}$, respectively, whereas from 1990 to 1995 , biomass steadily increased from 1.0 to $4.24 \mathrm{~kg} / \mathrm{ha}$ (P. Janssen, Idaho Department of Fish and Game, written commun., February 1996).

The recent increases in residential development and recreational use of Payette Lake, coupled with evidence of water-quality degradation and cultural eutrophication, prompted local residents to request a comprehensive water-quality study of the lake. The Idaho State Legislature responded by passing the Big Payette Lake Water Quality Act in 1993. The Act mandated formation of a water-quality council and development of a waterquality study of the lake and its watershed. The council requested technical assistance from the U.S. Geological Survey (USGS) for the limnological and eutrophication modeling components of the water-quality study. The IDEQ is the agency responsible for managing Idaho's lakes. They agreed to cooperatively fund the USGS portion of the water-quality study.

In August 1994, two major forest fires were ignited by lightning within Payette Lake's drainage basin; they burned into October before being extinguished by precipitation. The Blackwell and Corral Fires were of historic proportions because they were fueled by a 10 year drought, hot and windy weather, and dense stands of dead and dying trees (U.S. Forest Service, 1995b). Together the two fires burned about 50 percent of the drainage basin, primarily the eastern half and northern quarter. The fires presented a unique opportunity to study their effects on water quality in Payette Lake; however, they also necessitated revisions to the water-quality study to account for the additional nutrient loads from the fires.

The purpose of this cooperative study between the USGS and IDEQ was to determine Payette Lake's assimilative capacity for nutrients to assess its susceptibility to eutrophication. Five major tasks were undertaken: (1) Assess physical, chemical, and biological characteristics in the limnetic and littoral zones of the lake; (2) quantify loads of water and nutrients into and out of the lake; (3) develop an empirical nutrient load/ lake response model; (4) use the model to simulate the lake's response to hypothetical alterations in nutrient loads; and (5) estimate the nutrient loads added to the lake by the 1994 forest fires. The 3-year study began in October 1994; its geographic extent (fig. 1) was the drainage basin upstream from the USGS streamflowgaging station on the North Fork Payette River at McCall (station 13239000).

\section{DESCRIPTION OF STUDY AREA}

Payette Lake is a natural lake, formed by glacial activity, situated in the upper drainage basin of the Payette River, which drains into the Snake River in southwestern Idaho. Outflow from the lake is regulated for irrigation purposes by a small dam completed in 1943. The normal maximum lake surface elevation of $1,520 \mathrm{~m}$ above sea level is attained in July; a normal drawdown of $1.7 \mathrm{~m}$ is completed by December. The lake surface area and volume, excluding islands, are $20.5 \mathrm{~km}^{2}$ and $0.75 \mathrm{~km}^{3}$, respectively; mean and maximum depths are 36.8 and $92.7 \mathrm{~m}$, respectively; and shoreline length is about $36 \mathrm{~km}$. The principal tributary and outlet is the North Fork Payette River. 
Payette Lake receives drainage from $373 \mathrm{~km}^{2}$ of heavily forested, mountainous terrain. Elevations range from about $1,520 \mathrm{~m}$ at the lake outlet to about $2,768 \mathrm{~m}$ in the northeastern part of the study area. The geology is dominated by the Idaho batholith, which is characterized by crystalline igneous rocks. Three distinct geomorphic groups - glaciated lands, periglacial lands, and depositional lands - have been identified in the drainage basin (U.S. Forest Service, 1995b). Glaciated lands compose 70 percent of the area and include high-elevation mountain peaks and valleys shaped by glacial processes. Periglacial lands compose 4 percent of the area and include rolling uplands and smooth mountain slopes. Depositional lands compose 26 percent of the area and include moraines, outwash plains, and alluvial lands. The dominant vegetation is subalpine fir, Engelmann spruce, and lodgepole pine. Ownership and administration of land, in percentages, is as follows: U.S. Forest Service, 75; State of Idaho, 16; private, 3; and City of McCall, 1. The remaining 5 percent of the area is Payette Lake, which is owned by the State of Idaho. The major land uses are timber harvesting, recreation, residential development, and sheep grazing.

The area's climate is affected by easterly moving airmasses from the Pacific Ocean combined with orographic effects of the local mountains. The mean annual precipitation at McCall (elevation 1,520 m) is $660 \mathrm{~mm}$, whereas the mean annual precipitation at Secesh Summit (elevation 1,987 m) is $1,222 \mathrm{~mm}$ (U.S. Forest Service, 1995a). Precipitation at McCall during 1995 and 1996 was 830 and $730 \mathrm{~mm}$, respectively. Most precipitation is snow during October to May. Ice normally covers Payette Lake during late December to late April.

\section{HYDROLOGIC BUDGETS}

\section{Data Collection and Analysis}

Hydrologic budgets for Payette Lake were determined for water years 1995 and 1996. The budgets accounted for the mass of water entering and leaving the lake via pathways such as streamflow, precipitation, evaporation, and change in lake storage. Such data were important components of the nutrient load/lake response model and also were used to compute nutrient budgets for the lake. Hydrologic budgets were computed using the following equation (quantities in cubic hectometers):

$$
R=G T I+U T I+D S R+P-E-S W G O-M W-C S,
$$

where

$R$ is the residual;

GTI is gaged tributary inflow;

$U T I$ is ungaged tributary inflow;

$D S R$ is direct surface runoff;

$P$ is precipitation to the lake surface;

$E$ is evaporation from the lake surface;

$S W G O$ is gaged surface-water outflow;

$M W$ is municipal water withdrawal; and

$C S$ is change in lake storage.

Gaged tributary inflows were measured at the USGS gaging station 13238322, North Fork Payette River below Fisher Creek, and at IDEQ gaging stations near the mouths of Dead Horse and Fall Creeks (fig. 1). Gaged surface-water outflow was measured at the USGS gaging station 13239000, North Fork Payette River at McCall (fig. 1). Discharge at the two USGS gaging stations was determined from continuous monitoring of stage (water-surface elevation) and periodic measurements of streamflow using methods described by Buchanan and Somers $(1968,1969)$, Carter and Davidian (1968), Kennedy (1983, 1984), and Riggs (1968). Discharge was determined by IDEQ at its two gaging stations by relating periodic streamflow measurements to a stage-discharge curve, as described by the Payette Lake Technical Advisory Committee (written commun., 1997).

Ungaged tributary inflows were estimated by IDEQ by multiplying drainage-basin area by a unitrunoff coefficient determined at a nearby gaged surfacewater inflow station, either Dead Horse or Fall Creek (Payette Lake Technical Advisory Committee, written commun., 1997). Unit-runoff coefficients for Dead Horse and Fall Creeks were determined by dividing an-

Table 1. Annual coefficients for unit runoff and nutrient export for three gaged inflow stations and one gaged outflow station, 1995-96, Payette Lake

$\left[\mathrm{km}^{2}\right.$, square kilometer; $\mathrm{hm}^{3} / \mathrm{km}^{2}$, cubic hectometers per square kilometer; $\mathrm{kg} / \mathrm{km}^{2}$, kilograms per square kilometer; TP, total phosphorus; $\mathrm{TN}$, total nitrogen]

\begin{tabular}{|c|c|c|c|c|c|c|c|}
\hline \multirow{3}{*}{$\begin{array}{l}\text { Station name } \\
\text { (fig. 3) }\end{array}$} & \multirow{3}{*}{$\begin{array}{c}\text { Drainage } \\
\text { area } \\
\left(\mathbf{k m}^{2}\right)\end{array}$} & \multirow{2}{*}{\multicolumn{2}{|c|}{$\begin{array}{l}\text { Unit-runoff } \\
\text { coefficient } \\
\left(\mathbf{h m}^{3} / \mathbf{k m}^{2}\right)\end{array}$}} & \multicolumn{4}{|c|}{$\begin{array}{l}\text { Nutrient export coefficient } \\
\left(\mathbf{k g} / \mathbf{k m}^{2}\right)\end{array}$} \\
\hline & & & & \multicolumn{2}{|c|}{ TP } & \multicolumn{2}{|c|}{ TN } \\
\hline & & 1995 & 1996 & 1995 & 1996 & 1995 & 1996 \\
\hline $\begin{array}{l}\text { North Fork Payette River } \\
\text { below Fisher Creek... }\end{array}$ & 221 & 138 & 181 & 120 & 165 & 725 & 951 \\
\hline Dead Horse Creek ..... & 12.8 & .93 & .91 & 15.5 & 13.9 & 370 & 307 \\
\hline Fall Creek $\ldots \ldots \ldots \ldots$ & 17.3 & 1.00 & .88 & 842 & 46.4 & 1,500 & 797 \\
\hline $\begin{array}{l}\text { North Fork Payette River } \\
\text { at McCall.......... }\end{array}$ & 373 & 1.09 & 1.42 & 6.2 & 8.0 & 278 & 400 \\
\hline
\end{tabular}


nual discharge, in cubic hectometers, by drainage-basin area, in square kilometers (table 1).

Direct surface runoff was estimated by IDEQ using methods described by the Payette Lake Technical Advisory Committee (written commun., 1997). These methods followed those of Schueler (1987), who estimated runoff by relating precipitation, infiltration, percentage of impervious surfaces, and soil moisture storage.

Precipitation to the lake surface was determined by multiplying lake surface area by the precipitation recorded during water years $1995(0.83 \mathrm{~m})$ and $1996(0.73$ $\mathrm{m})$ at the National Weather Service station in McCall. Evaporation from the lake surface was estimated by multiplying lake surface area by an annual evaporation rate of $0.76 \mathrm{~m}$. The evaporation rate was derived from a map of annual free-water-surface evaporation in Idaho (Myron Molnau and K.C.S. Kpordze, University of Idaho, written commun., 1992). The change in lake storage was determined with a combination of lake stage data collected at USGS station 13238500, Payette Lake at McCall, and area and volume curves (fig. 2) generated by this study. An evaluation of ground-water flux for Payette Lake was beyond the scope of this study.

The residual for the hydrologic budget was computed as the difference between inflow and outflow minus change in lake storage. The residual included the errors associated with all budget components and unmeasured components such as ground-water flux and bank-storage flux.

The error associated with the hydrologic budget was computed using methods described by Winter (1981) and Brown (1987). The error associated with each budget component was computed using the following equation (Brown, 1987):

$$
E=\left[\left(P^{2}\right)\left(C^{2}\right)\right]^{0.5},
$$

where

$E$ is total standard error associated with budget component $C$;

$P$ is percent error used to determine budget component $C$; and

$C$ is value of budget component.

Percent error for each budget component was adapted from a report by Winter (1981). Assignment of percent error to each budget component was as follows: gaged surface-water inflow and outflow and change in lake storage, 7.5 percent; precipitation, 15 percent; other components, 25 percent. Total error for the hydrologic budget was computed using the following equation (Brown, 1987):

$$
O E=\left[\left(E_{1}\right)^{2}+\left(E_{2}\right)^{2}+\ldots+\left(E_{n}\right)^{2}\right]^{0.5},
$$

where

$O E$ is overall standard error associated with hydrologic budget, in cubic hectometers; and

$E_{n}$ is total standard error associated with each budget component.

\section{Streamflow}

Daily mean streamflow, in cubic meters per second, at the primary inflow station, North Fork Payette River below Fisher Creek, averaged 9.7 during 1995 and 12.6 during 1996 (Brennan and others, 1996, 1997). The range in daily mean streamflow, in cubic meters per second, at the primary inflow station was from 0.12 (October 9) to 81.3 (June 3) during 1995; and from 0.42 (August 17) to 113 (May 18) during 1996. About 71 per-

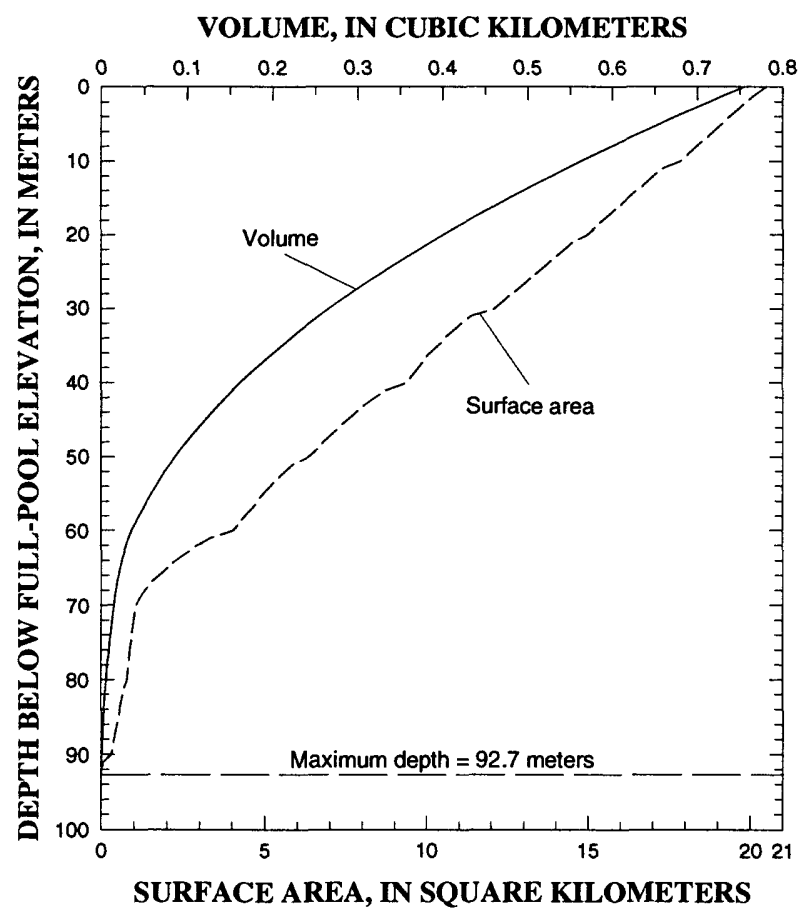

Figure 2. Relation of depth to lake surface area and volume for Payette Lake. 
cent of the annual streamflow in 1995 was delivered during May and June; in 1996, about 54 percent was delivered during May and June. The short, 2-year period of record at this station precluded any historical streamflow comparisons.

Daily mean streamflow, in cubic meters per second, at the lake outlet station, North Fork Payette River at McCall, averaged 12.9 in 1995 and 14.9 in 1996. The range in daily mean streamflow, in cubic meters per second, was from 1.13 (January 6) to 89.8 (June 5) during 1995; and from 0.79 (August 19) to 126 (June 18) during 1996. About 66 percent of the annual outflow occurred during May and June in 1995; about 56 percent occurred during May and June in 1996. Annual mean streamflow for the period of record at this station, which began in 1908, is $10.1 \mathrm{~m}^{3 / \mathrm{s}}$. Annual streamflow for 1995 was 128 percent of the historical annual mean and, for 1996 , was 148 percent.

Streamflow measured by IDEQ at Dead Horse and Fall Creeks was substantially less than that measured at the two USGS stations. Daily mean streamflow, in cubic meters per second, in Dead Horse Creek was 0.37 in 1995 and 0.36 in 1996, and in Fall Creek, was 0.55 in 1995 and 0.48 in 1996. During both years, more than half of the streamflow in the two creeks was delivered during May and June.

Residence time represents the time theoretically required for the outflow to empty a lake and is determined by dividing lake volume by outflow volume. Payette Lake's water-residence time for 1995 and 1996 was 1.84 and 1.42 years, respectively. The larger outflow volume in 1996 would have emptied the lake more rapidly than in 1995 . Historically, the outflow volume has averaged $10.1 \mathrm{~m} 3 / \mathrm{s}$, which yields a residence time of 2.35 years. Thus, during this 2-year study, water in Payette Lake had shorter residence times than normal.

\section{Hydrologic Budgets}

Inflow to Payette Lake during 1995-96 was dominated by the North Fork Payette River, a gaged stream (table 2). The other two gaged streams, Dead Horse and Fall Creeks, provided less than 7 percent of the inflow. Ungaged tributaries plus direct surface runoff from the 23.5 percent of the watershed area not directly measured by the three gaging stations provided the second-largest inflow. Precipitation on the lake's surface provided about 1 percent of the inflow. More

Table 2. Hydrologic budget and errors associated with each budget component, 1995-96, Payette Lake

[Volumes and errors are in cubic hectometers]

\begin{tabular}{|c|c|c|c|c|c|c|}
\hline \multirow[b]{3}{*}{ Budget component } & \multicolumn{3}{|c|}{1995} & \multicolumn{3}{|c|}{1996} \\
\hline & \multicolumn{2}{|c|}{ Inflow or outflow } & \multirow[b]{2}{*}{ Error } & \multicolumn{2}{|c|}{ Inflow or outflow } & \multirow[b]{2}{*}{ Error } \\
\hline & Volume & $\begin{array}{l}\text { Percent } \\
\text { of total }\end{array}$ & & Volume & $\begin{array}{l}\text { Percent } \\
\text { of total }\end{array}$ & \\
\hline & \multicolumn{3}{|c|}{ Inflow } & \multicolumn{3}{|c|}{ Inflow } \\
\hline North Fork Payette River . & 304 & 70.7 & 22.8 & 399 & 74.8 & 29.9 \\
\hline Fall Creek . . . . . . . . . & 17.3 & 4.0 & 1.3 & 15.3 & 2.8 & 1.1 \\
\hline Dead Horse Creek. & 11.7 & 2.7 & .9 & 11.4 & 2.1 & .9 \\
\hline Ungaged tributaries... & 90 & 20.8 & 22 & 101 & 18.9 & 25 \\
\hline Direct surface runoff $\ldots . \ldots \ldots$ & 2.9 & .7 & .7 & 2.7 & .5 & .7 \\
\hline \multirow[t]{2}{*}{ Precipitation $\ldots \ldots \ldots \ldots \ldots$} & 4.7 & 1.1 & 4.0 & 4.1 & .9 & 6 \\
\hline & \multicolumn{3}{|c|}{ Outflow } & \multicolumn{3}{|c|}{ Outflow } \\
\hline North Fork Payette River & 408 & 96.3 & 30.6 & 528 & 97.1 & 39.6 \\
\hline Evaporation ............ & 4.3 & 1.0 & 1.2 & 4.2 & .8 & 1.0 \\
\hline \multirow[t]{2}{*}{ Municipal withdrawal $\ldots \ldots \ldots$} & 11.4 & 2.7 & 2.9 & 11.4 & 2.1 & 2.8 \\
\hline & \multicolumn{3}{|c|}{ Summary } & \multicolumn{3}{|c|}{ Summary } \\
\hline Total inflow ...... & \multirow{2}{*}{\multicolumn{3}{|c|}{431}} & \multicolumn{3}{|c|}{534} \\
\hline Total outflow ......... & \multicolumn{2}{|r|}{424} & & \multicolumn{3}{|c|}{544} \\
\hline Change in lake storage .. & \multicolumn{3}{|c|}{30} & \multicolumn{3}{|c|}{-87} \\
\hline Residual $^{1} \ldots \ldots \ldots \ldots$ & \multicolumn{3}{|c|}{-23} & \multicolumn{3}{|c|}{77} \\
\hline Overall error ...... & \multicolumn{3}{|c|}{44} & \multicolumn{3}{|c|}{56} \\
\hline
\end{tabular}

${ }^{1}$ (Total inflow minus total outflow) minus change in lake storage. 
than 95 percent of the outflow was via the lake's outlet, the North Fork Payette River. The remaining outflow evaporated from the lake surface or was withdrawn by the City of McCall for its municipal water supply.

The residual of the hydrologic budget was small in both years and inflows were nearly balanced by outflows; thus, no definitive statement can be made about inflow or outflow of ground water. Overall error was about 10 percent of total inflow in both years.

\section{NUTRIENT BUDGETS}

\section{Data Collection and Analysis}

Nutrient budgets for total phosphorus and total nitrogen were determined for water years 1995 and 1996 to assess the relative and absolute magnitudes of nutrient loads contributed by various point and nonpoint source areas. The budgets were calculated by multiplying the hydrologic quantities in equation 1 by their associated nutrient concentrations. Phosphorus concentrations for this study are reported as total phosphorus and dissolved orthophosphorus, as phosphorus. Total phosphorus represents the phosphorus in solution and contained in or attached to biotic and abiotic particulate material. Dissolved orthophosphorus is determined from the filtrate that passes through a filter with a nominal pore size of $0.45 \mu \mathrm{m}$. Nitrogen concentrations for this study were analyzed as total ammonia plus organic nitrogen (commonly called kjeldahl nitrogen), dissolved ammonia, and dissolved nitrite plus nitrate, as nitrogen. Total ammonia plus organic nitrogen represents the ammonia (includes ammonium) and organic nitrogen compounds in solution and associated with biotic and abiotic particulate material. Total nitrogen represents the sum of total ammonia plus organic nitrogen and dissolved nitrite plus nitrate. The dissolved concentrations represent the ammonia (includes ammonium) or nitrite plus nitrate in filtrate that passes through a $0.45-\mu \mathrm{m}$ filter.

The nutrient loads delivered by the lake's primary inlet and outlet tributaries (USGS gaging stations 13238322 and 13239000 ) were determined using nutrient concentration data collected concurrently with streamflow measurements (Brennan and others, 1996, 1997). Nutrient samples were collected over a wide range of discharges using standardized USGS crosssectional, depth-integrating methods (Edwards and Glysson, 1988). The samples were analyzed for total concentrations of phosphorus and organic plus ammonia nitrogen, and dissolved concentrations of orthophosphorus, nitrite plus nitrate, and ammonia at the USGS National Water Quality Laboratory using lowlevel detection limit methods as described by Fishman and Friedman (1989) and quality assurance/quality control procedures described by Pritt and Raese (1995).

Approximately 10 percent of the nutrient samples were submitted as duplicates or blanks for quality assurance purposes as described by Friedman and Erdmann (1982).

The nutrient loads contributed by Dead Horse and Fall Creeks were determined using either flowweighted samples collected by an automated sampler or cross-sectional, depth-integrated samples (Payette Lake Technical Advisory Committee, written commun., 1997). The samples were analyzed by the Idaho Bureau of Laboratories for total concentrations of phosphorus, organic plus ammonia nitrogen, ammonia, and nitrite plus nitrate, and dissolved concentrations of orthophosphorus.

Nutrient loads from ungaged tributary inflows were estimated by IDEQ by multiplying drainage area, in square kilometers, by a nutrient-export coefficient, in kilograms per square kilometer (Payette Lake Technical Advisory Committee, written commun., 1997). The nutrient-export coefficients were calculated by IDEQ by dividing nutrient load, in kilograms, by watershed area, in square kilometers.

Nonpoint source nutrient loads from direct surface runoff were estimated by IDEQ (Payette Lake Technical Advisory Committee, written commun., 1997) using methods described by Schueler (1987). The annual nutrient load was calculated using equations that combine runoff volume with nutrient concentrations periodically sampled from commercial, residential, and sparsely developed areas.

Atmospheric input of nutrients to the lake surface was estimated using data from the National Atmospheric Deposition Program's monitoring station at Smiths Ferry (65 km south of McCall). The annual areal deposition rates, in kilograms per square kilometer, were multiplied by lake surface area, in square kilometers, to determine the annual load to Payette Lake. The nutrient load associated with the annual change in lake storage was determined by multiplying that volume, in cubic hectometers, by the mean annual concentration of nutrients, in micrograms per liter, in the epilimnion of limnetic station 1. 
The residual for each nutrient budget was computed as the difference between the inflow and outflow of nutrients minus the nutrient load associated with the change in lake storage. The residual contains the errors associated with all budget components and unmeasured components such as ground-water flux.

Errors associated with each component of a nutrient budget were computed using errors in the hydrologic budget and errors in the collection and analysis of nutrient concentration data. Assignment of percent error to each concentration in a nutrient budget was as follows: gaged surface-water inflow and outflow and change in lake storage, 15 percent; ungaged inflow and precipitation, 30 percent. Total error for each budget component was computed using the following equation (Brown, 1987):

$$
E=\left\{\left[\left(E_{c}\right)^{2}(Q)^{2}\right]+\left[\left(E_{q}\right)^{2}(C)^{2}\right]\right\}^{0.5},
$$

where

$E$ is total standard error associated with each budget component, in kilograms;

$E_{c}$ is standard error associated with each nutrient concentration, in micrograms per liter;

$Q$ is quantity of water, in cubic hectometers;

$E_{q}$ is standard error associated with quantity of water, in cubic hectometers; and

$C$ is nutrient concentration, in micrograms per liter.

Overall error for each nutrient budget was computed with the following equation (Brown, 1987):

$$
O E=\left[\left(E_{1}\right)^{2}+\left(E_{2}\right)^{2}+\ldots+\left(E_{n}\right)^{2}\right]^{0.5},
$$

where

$O E$ is overall standard error associated with nutrient budget, in kilograms; and

$E_{n}$ is total standard error associated with each budget component.

\section{Nutrient Budgets}

Substantially more total phosphorus entered Payette Lake in 1995-96 than was discharged from the lake (table 3). In 1995, 55.5 percent of the incoming load was from Fall Creek, a drainage that was heavily affected by the 1994 forest fires. The magnitude of the load from Fall Creek was strongly influenced by two samples containing high total phosphorus concentrations $(2,620$ and $1,300 \mu \mathrm{g} / \mathrm{L}$ ) collected during peak streamflow in May and June 1995, respectively. In 1995, the second-largest load, 28 percent, was from ungaged tributaries, 10.1 percent was from the North Fork Payette River, and 2.5 percent was from atmospheric deposition. In 1996, only 10.2 percent of the load was from Fall Creek, a large reduction from the previous year; 46.3 percent was from the North Fork Payette River; 23.6 percent was from ungaged tributaries; and 8.4 percent was from atmospheric deposition. In both years, the City of McCall's municipal water withdrawal accounted for about 2 percent of the outflow of total phosphorus; the remainder was through the lake's outlet.

Analogous to total phosphorus, substantially more total nitrogen entered Payette Lake in 1995-96 than was discharged (table 4). The North Fork Payette River inflow dominated the inflow budget in both years; the second-largest contribution was from ungaged tributaries. Less than 3 percent of the load was from atmospheric deposition. About 2 percent of the outflow of total nitrogen was municipal water withdrawal; the remainder was through the lake's outlet.

Payette Lake functioned as a trap for total phosphorus and total nitrogen, as indicated by the overall errors being much less than the residuals in each nutrient budget (tables 3 and 4). Comparison of the residual to the total inflow indicates that the lake trapped about 90 and 68 percent of the total phosphorus inflow in 1995 and 1996, respectively. The lake trapped about 55 and 53 percent of the total nitrogen load in 1995 and 1996, respectively. The high trapping efficiency of the lake is due, in part, to long water-residence time and the presence of a shallow morphometric constriction between the northern and southwestern basins.

The total and dissolved nutrient loads were differentiated for the two North Fork Payette River stations (table 5) to assess the effect of water-residence time on inflow and outflow loads. The percentage of dissolved orthophosphorus to total phosphorus for both years averaged 22.4 percent for the inflow station and declined to 15.6 percent for the outflow station. Similarly, the percentage of dissolved inorganic nitrogen to total nitrogen for both years averaged 67.1 percent for the inflow station and declined to 34 percent for the outflow station. The decline is attributable, in part, to phyto- 
Table 3. Total phosphorus budget and errors associated with each budget component, 1995-96, Payette Lake

[Loads and errors are in kilograms]

\begin{tabular}{|c|c|c|c|c|c|c|}
\hline \multirow[b]{3}{*}{ Budget component } & \multicolumn{3}{|c|}{1995} & \multicolumn{3}{|c|}{1996} \\
\hline & \multicolumn{2}{|c|}{ Inflow or outflow } & \multirow[b]{2}{*}{ Error } & \multicolumn{2}{|c|}{ Inflow or outflow } & \multirow[b]{2}{*}{ Error } \\
\hline & Volume & $\begin{array}{c}\text { Percent } \\
\text { of total }\end{array}$ & & Volume & $\begin{array}{c}\text { Percent } \\
\text { of total }\end{array}$ & \\
\hline & \multicolumn{3}{|c|}{ Inflow } & \multicolumn{3}{|c|}{ Inflow } \\
\hline North Fork Payette River. . . . . & 2,660 & 10.1 & 443 & 3,640 & 46.3 & 621 \\
\hline Fall Creek. . . . . . . . . . . & 14,600 & 55.5 & 2,440 & 803 & 10.2 & 134 \\
\hline Dead Horse Creek . . . . . . . . . & 198 & .8 & 33 & 178 & 2.3 & 30 \\
\hline Ungaged tributaries $\ldots \ldots \ldots \ldots$ & 7,360 & 28 & 2,850 & 1,860 & 23.6 & 721 \\
\hline Direct surface runoff $\ldots \ldots \ldots$ & 818 & 3.1 & 315 & 725 & 9.2 & 287 \\
\hline \multirow[t]{2}{*}{ Precipitation $\ldots \ldots \ldots \ldots \ldots$} & 660 & 2.5 & 594 & 660 & 8.4 & 220 \\
\hline & \multicolumn{3}{|c|}{ Outflow } & \multicolumn{3}{|c|}{ Outflow } \\
\hline North Fork Payette River. . . . . & 2,300 & 97.9 & 369 & 2,960 & 97.7 & 477 \\
\hline \multirow[t]{2}{*}{ Municipal withdrawal $\ldots \ldots$. } & 49 & 2.1 & 19 & 69 & 2.3 & 27 \\
\hline & \multicolumn{3}{|c|}{ Summary } & \multicolumn{3}{|c|}{ Summary } \\
\hline Total inflow $\ldots \ldots \ldots \ldots \ldots$ & \multicolumn{3}{|c|}{26,300} & \multicolumn{3}{|c|}{7,870} \\
\hline Total outflow . . . . . . . . & \multicolumn{3}{|c|}{2,350} & \multicolumn{3}{|c|}{3,030} \\
\hline Change in lake storage. . . . . . & \multicolumn{3}{|c|}{129} & \multicolumn{3}{|c|}{-531} \\
\hline Residual $^{1} \ldots \ldots \ldots \ldots \ldots$ & \multicolumn{3}{|c|}{23,800} & \multicolumn{3}{|c|}{5,370} \\
\hline Overall error. . . . . . . . . . . & \multicolumn{3}{|c|}{3,860} & \multicolumn{3}{|c|}{1,110} \\
\hline
\end{tabular}

${ }^{1}$ (Total inflow minus total outflow) minus change in lake storage.

Table 4. Total nitrogen budget and errors associated with each budget component, 1995-96, Payette Lake

[Loads and errors are in kilograms]

\begin{tabular}{|c|c|c|c|c|c|c|}
\hline \multirow[b]{3}{*}{ Budget component } & \multicolumn{3}{|c|}{1995} & \multicolumn{3}{|c|}{1996} \\
\hline & \multicolumn{2}{|c|}{ Inflow or outflow } & \multirow[b]{2}{*}{ Error } & \multicolumn{2}{|c|}{ Inflow or outflow } & \multirow[b]{2}{*}{ Error } \\
\hline & Volume & $\begin{array}{l}\text { Percent } \\
\text { of total }\end{array}$ & & Volume & $\begin{array}{l}\text { Percent } \\
\text { of total }\end{array}$ & \\
\hline & \multicolumn{3}{|c|}{ Inflow } & \multicolumn{3}{|c|}{ Inflow } \\
\hline North Fork Payette River & 160,000 & 64.4 & 26,800 & 210,000 & 74.5 & 35,200 \\
\hline Fall Creek . . . . . . . . . & 26,000 & 10.4 & 4,350 & 13,800 & 4.9 & 2,290 \\
\hline Dead Horse Creek . . . & 4,730 & 1.9 & 797 & 3,930 & 1.4 & 667 \\
\hline Ungaged tributaries . . & 48,100 & 19.3 & 18,600 & 44,600 & 15.8 & 17,400 \\
\hline Direct surface runoff . . . . . . . & 3,530 & 1.4 & 1,360 & 2,970 & 1.1 & 1,180 \\
\hline \multirow[t]{2}{*}{ Precipitation $\ldots \ldots \ldots \ldots \ldots$} & 6,560 & 2.6 & 5,920 & 6,560 & 2.3 & 2,190 \\
\hline & \multicolumn{3}{|c|}{ Outflow } & \multicolumn{3}{|c|}{ Outflow } \\
\hline North Fork Payette River . . . . . & 104,000 & 98.1 & 17,400 & 149,000 & 97.7 & 477 \\
\hline \multirow[t]{2}{*}{ Municipal withdrawal $\ldots \ldots \ldots$} & 1,890 & 1.9 & 740 & 2,530 & 2.3 & 27 \\
\hline & \multicolumn{3}{|c|}{ Summary } & \multicolumn{3}{|c|}{ Summary } \\
\hline Total inflow . . . . . . . . & \multicolumn{3}{|c|}{249,000} & \multicolumn{3}{|c|}{282,000} \\
\hline Total outflow . . . . . . . & \multicolumn{3}{|c|}{106,000} & \multicolumn{3}{|c|}{152,000} \\
\hline Change in lake storage & \multicolumn{3}{|c|}{4,980} & \multicolumn{3}{|c|}{$-19,300$} \\
\hline Residual $^{1} \ldots \ldots \ldots$ & \multicolumn{3}{|c|}{138,000} & \multicolumn{3}{|c|}{149,000} \\
\hline Overall error. & \multicolumn{3}{|c|}{37,700} & \multicolumn{3}{|c|}{46,700} \\
\hline
\end{tabular}

${ }^{1}$ (Total inflow minus total outflow) minus change in lake storage. 
Table 5. Loads of nitrogen and phosphorus for water years 1995 and 1996 at North Fork Payette River below Fisher Creek (13238322) and North Fork Payette River at McCall (13239000)

[kg/yr, kilograms per year; TP, total phosphorus; DOP, dissolved orthophosphorus; TN, total nitrogen; TON, total organic nitrogen; DIN, dissolved inorganic nitrogen; $\mathrm{DN}+\mathrm{N}$, dissolved nitrite plus nitrate; DAMM, dissolved ammonia]

\begin{tabular}{lcrr}
\hline \multirow{2}{*}{ Station } & & \multicolumn{2}{c}{ Load (kg/yr) } \\
\cline { 3 - 4 } 13238322 & Constituent & 1995 & 1996 \\
& TP & 2,660 & 3,640 \\
& DOP & 591 & 820 \\
& TN & 160,000 & 210,000 \\
& TON & 52,800 & 69,300 \\
& DIN & 107,000 & 141,000 \\
& DN + N & 106,200 & 139,400 \\
13239000 & DAMM & 1,200 & 1,570 \\
& TP & 2,300 & 2,960 \\
& DOP & 356 & 462 \\
& TN & 104,000 & 149,000 \\
& TON & 66,200 & 101,200 \\
& DIN & 37,400 & 47,500 \\
& DN + N & 36,600 & 46,400 \\
& DAMM & 733 & 973 \\
\hline
\end{tabular}

plankton and periphyton assimilation and conversion to the particulate nutrient pool.

About $55 \mathrm{~kg}$ of nitrogen and $7 \mathrm{~kg}$ of phosphorus also were added to Payette Lake from decomposition of kokanee salmon carcasses remaining from the autumn spawning runs into the lower reach of the North Fork Payette River during 1995 and 1996. These nutrient loads would have been a small percentage addition and were not reported in the nutrient budgets (tables 3 and 4). The loads were calculated using two data sources. Data from IDFG on numbers of spawning fish, mean biomass per fish, and predation losses (P. Janssen, Idaho Department of Fish and Game, written commun., 1996) were multiplied by the percentage composition of nitrogen and phosphorus in the carcasses. Nitrogen and phosphorus composed 3.0 and 0.364 percent, respectively, of the biomass of rainbow trout (Oncorhynchus mykiss) as reported by Schuldt and Hershey (1995); these values were assumed to apply to kokanee salmon in the North Fork Payette River. Although this load was a small addition to Payette Lake's nutrient budget, salmon dieoff occurs annually and, thus, represents a long-term, cumulative nutrient load.

An unquantified nutrient load to Payette Lake was from periphyton in the North Fork Payette River between station 13238322 and the inlet to Payette Lake (fig. 1). This lowermost reach of the river supports a substantial amount of periphyton during the summer, partly because this is a quiescent reach affected by backwater from Payette Lake. Backwater conditions were produced when the river was dammed in the early 1940's. In the autumn and winter, the periphyton become senescent and some part, in both particulate and dissolved forms, is scoured and transported into the lake with streamflow. This nutrient load is probably not large in relation to the lake's nutrient budget but represents another long-term, cumulative nutrient load.

\section{Effects of Fire on Nutrient Budgets}

A well-documented effect of forest fires has been the increase in nutrient loads delivered to receiving waters (Grier, 1975; Tiedemann and others, 1979; Schindler and others, 1980; Tiedemann, 1981; Helvey and others, 1985); thus, some part of the nitrogen and phosphorus loads delivered to Payette Lake in 1995-96 were attributable to the 1994 forest fires that burned about one-half of the lake's watershed. Fires affect a forest's nutrient balance in four principal ways: They remove nutrients from the site, redistribute nutrients as ash, temporarily disrupt normal nutrient-cycling processes, and increase the flow of water and nutrients to the soil mantle (Tiedemann, 1981). Although combustion renders nitrogen and phosphorus more available for transport to receiving waters, most studies showed that nitrogen loads were increased substantially more than phosphorus loads (Tiedemann and others, 1979; Schindler and others, 1980) because the potential phosphorus load was attenuated by its adsorption to soil particles. However, several mechanisms enhance transport of nitrogen to receiving waters (Tiedemann, 1981). Nitrogen in redeposited ash is readily leachable and moves into the soil mantle where it can be transported as surface or subsurface runoff. Nitrogen transported in runoff also can be increased by the loss of vegetation, which reduces uptake of soil nitrogen. Another important mechanism is nitrification, which is enhanced by favorable changes in soil $\mathrm{pH}$ and electrolyte concentrations following a forest fire (Ahlgren and Ahlgren, 1960). An additional fire-related source of nitrogen and phosphorus for Payette Lake is the large quantity of fire retardant airdropped onto the watershed during the 1994 fires.

An estimate of the nutrient load added to Payette Lake's watershed by the 1994 fires was developed on the basis of previously published studies and data on fire retardant composition and amounts dropped on the wa- 
tershed. The most applicable studies were of the 1970 Entiat fire in eastern Washington (Grier, 1975; Tiedemann, 1981) because the tree species mix at Entiat was similar to that at Payette Lake. The ash residue from the Entiat fire averaged $2,900 \mathrm{~kg} / \mathrm{ha}$ and contained an average of $23 \mathrm{~kg} / \mathrm{ha}$ of nitrogen (Grier, 1975). The 1994 fires at Payette Lake burned about 20,000 ha in a species mix considered by Tiedemann (1981) to have a very high nitrogen content. On the basis of results from the Entiat fire, the Payette Lake fire produced an ash residue of 58 million $\mathrm{kg}$ that contained $460,000 \mathrm{~kg}$ of nitrogen. The phosphorus content of the Entiat ash was not determined, but the ratio of nitrogen and phosphorus yields was 11.4:1 for post-fire conditions (Helvey and others 1985). On that basis, the ash from the Payette Lake fire contained about $2.3 \mathrm{~kg} / \mathrm{ha}$ of phosphorus; thus, the ashassociated phosphorus was $46,000 \mathrm{~kg}$. No data were found that would allow estimation of the additional nitrogen loads attributable to enhanced nitrification. The amounts of nitrogen and phosphorus added by fire retardant drops were 2,500 and $830 \mathrm{~kg}$, respectively. These estimates were derived by multiplying the amount of retardant dropped on the watershed by the retardant's nitrogen and phosphorus content (J. Fitzgerald, U.S. Forest Service, written commun., 1995). The nutrient contribution from fire retardant was less than 1 percent of that added by the ash residue.

The fires' substantial addition of nutrients to Payette Lake's watershed led to increases in nutrient concentrations in streams draining to the lake. Nutrient concentration data from the 1975 National Eutrophication Survey of Payette Lake (U.S. Environmental Protection Agency, 1977) were used to estimate the magnitude of such increases. On the basis of 11 samples taken from the North Fork Payette River near the lake's inlet, total inorganic nitrogen and total phosphorus averaged 68 and $10 \mu \mathrm{g} / \mathrm{L}$, respectively, during the 1975 water year. When the 1975 streamflow of the North Fork Payette River near the lake's inlet, $240 \mathrm{hm}^{3}$, was multiplied by the 1975 mean nutrient concentrations, the resultant nutrient loads for 1975 were $16,320 \mathrm{~kg}$ of total inorganic nitrogen and $2,400 \mathrm{~kg}$ of total phosphorus. These loads were representative of average conditions because streamflow at the lake outlet during 1975 was 108 percent of the long-term mean. When the 1975 mean nutrient concentrations were multiplied by the North Fork Payette River's 1996 streamflow, the resultant $1995 \mathrm{nu}-$ trient loads were $20,700 \mathrm{~kg}$ of total inorganic nitrogen and $3,040 \mathrm{~kg}$ of total phosphorus. Likewise, the resultant 1996 nutrient loads were $27,100 \mathrm{~kg}$ of total inorgan- ic nitrogen and 3,990 kg of total phosphorus. Annual loads of total phosphorus delivered by the North Fork Payette River in 1995 and 1996 (table 5) were about equal to those calculated using 1975 concentrations; however, annual loads of dissolved inorganic nitrogen delivered by the North Fork Payette River in 1995 and 1996 were about five times larger than those calculated using 1975 concentrations.

A different picture emerges for Fall Creek, the largest source of phosphorus to the lake in 1995 (table 3). According to National Eutrophication Survey data for 14 samples collected from Fall Creek during 1975 (U.S. Environmental Protection Agency, 1977), average concentrations of total inorganic nitrogen and total phosphorus were 504 and $15 \mu \mathrm{g} / \mathrm{L}$, respectively. When the 1975 streamflow of Fall Creek, $14 \mathrm{hm}^{3}$, was multiplied by the 1975 mean nutrient concentrations, the resultant nutrient loads for 1975 were $7,060 \mathrm{~kg}$ of total inorganic nitrogen and $210 \mathrm{~kg}$ of total phosphorus. When the 1975 mean nutrient concentrations were multiplied by Fall Creek's 1995 streamflow, the resultant 1995 nutrient loads were $8,720 \mathrm{~kg}$ of total inorganic nitrogen and $260 \mathrm{~kg}$ of total phosphorus. The annual load of total inorganic nitrogen delivered by Fall Creek in 1995 (table 4) was about three times larger than that calculated using 1975 concentrations; however, the annual load of total phosphorus delivered by Fall Creek in 1995 (table 3) was about 56 times larger than that calculated using 1975 concentrations.

\section{LIMNOLOGY}

\section{Data Collection and Analysis}

The physical, chemical, and biological functions of a lake are important factors in determining its susceptibility to eutrophication. The nutrient load/lake response model used to assess eutrophication in Payette Lake required a large amount of limnological data to simulate the lake's response to changes in nutrient loadings. Limnological data were collected in the limnetic zone and the littoral zone; these data have been tabulated in reports by Brennan and others $(1996,1997)$.

\section{LIMNETIC ZONE}

Four limnetic stations (fig. 3) were sampled from October 1994 through September 1996. Each station 
represented an important and distinct limnetic zone within the lake. Station 1 monitored the large volume of water in the lake's southwest basin and was nearest the lake's outlet. Station 2 monitored the small basin that connected the southwest and northern basins. Station 3 monitored the northern basin, which was the deepest $(92.7 \mathrm{~m})$ and was nearest the lake's primary tributary. Station 4 monitored the southeastern basin, which was the shallowest $(37.2 \mathrm{~m})$ and most hydrologically isolated from the primary tributary.

Sampling at the four limnetic stations typically was performed triweekly during May through October; one trip occurred in February 1996 when the lake was ice covered. A water-column profile of photosynthetically active radiation (PAR) was made with a spherical quantum sensor and planar deck-cell sensor to determine the euphotic-zone depth and compute an extinction coefficient. The euphotic zone is defined as that part of the water column in which in situ PAR is equal to or greater than 1 percent of the PAR incident upon the lake surface. Water-column transparency was measured with a $20-\mathrm{cm}$-diameter secchi disc for later correlation with the PAR data. A full-depth profile of water temperature, specific conductance, $\mathrm{pH}$, dissolved-oxygen concentration, and percent saturation was made with a multiparameter water-quality profiling instrument (Hydrolab Surveyor II). A nonmetallic water-sampling bottle was used to obtain three samples: euphotic-zone composite, mid-depth, and $1 \mathrm{~m}$ above the lake bottom. Each water sample was analyzed for concentrations of total phosphorus and ammonia plus organic nitrogen and dissolved ammonia, nitrite plus nitrate, and orthophosphorus. The euphotic-zone composite also was analyzed for chlorophyll- $a$ and phytoplankton taxonomy. The chlorophyll- $a$ sample was obtained by filtering $500 \mathrm{~mL}$ of sample water through a prerinsed, glass-fiber filter (Whatman GF/F), which was immediately frozen until analysis. The phytoplankton sample was preserved with Lugol's solution. Nutrient samples were analyzed at the USGS National Water Quality Laboratory using lowlevel detection limit methods as described by Fishman and Friedman (1989) and quality assurance/quality control procedures as described by Pritt and Raese (1995). Approximately 10 percent of the nutrient samples were submitted as duplicates or blanks for quality assurance purposes as described by Friedman and Erdmann (1982). Chlorophyll- $a$ was analyzed according to Britton and Greeson (1989) using high performance liquid chromatography. Aquatic Analysts of Portland, Oregon, evalu- ated the phytoplankton samples for taxonomic composition, density, biomass, and diversity indices.

During July 1996, the surficial lakebed sediments at the four limnetic stations were sampled using a stainless-steel Ponar dredge. Each sample was analyzed for total phosphorus and nitrogen using methods described by Fishman and Friedman (1989).

\section{LITTORAL ZONE}

Nutrient and chlorophyll- $a$ samples were collected from the 1-m depth at 25 littoral stations (fig. 3) during August and September 1995 to aid in selection of stations to monitor periphyton production. Sampling protocol paralleled that used for limnetic sampling. During July and August 1996, 20 of the 25 littoral stations were equipped with artificial substrates to monitor periphyton production in relation to nearshore influences. Artificial substrates were chosen instead of natural substrates to reduce the number of environmental variables used for the statistical evaluation. The substrates were placed on July 23 and 24, were incubated in situ for about 30 days, and were retrieved on August 20 and 21 .

Each artificial substrate consisted of a 5-cm-diameter unglazed ceramic ball affixed with adhesive to a 0.5 -m-long rigid plastic shaft. At each station, three substrates were held vertically by a concrete-filled, plastic bucket. The bucket was placed on the lakebed so that the ceramic balls were about $2 \mathrm{~m}$ beneath the lake surface and about $0.5 \mathrm{~m}$ above the lakebed. This design and placement reduced the potential losses of periphyton due to benthic-invertebrate grazing and wave-induced sloughing. The amount of PAR received by each station during the incubation was computed so periphyton growth, quantified as chlorophyll- $a$, could be normalized to PAR. A LiCor solar monitor (model LI-1776) located on the southeast shore of Payette Lake recorded the hourly input of PAR. The amount of shading by the horizon, nearby structures, and vegetation at each station was quantified using a solar-pathfinder instrument. This allowed adjustment of the incubation PAR data to account for differences in incident PAR at each station. Finally, the PAR received during incubation at each station's substrates was computed with the following equation: 


\section{EXPLANATION}

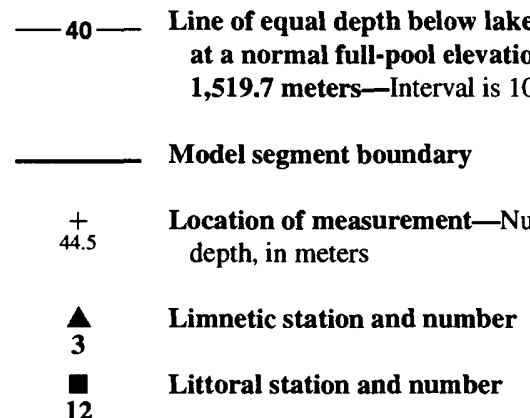

Base from U.S. Geological Survey digital data, 1:24,000, McCall,1973 Universal Transverse Mercator (UTM) projection, Zone 11

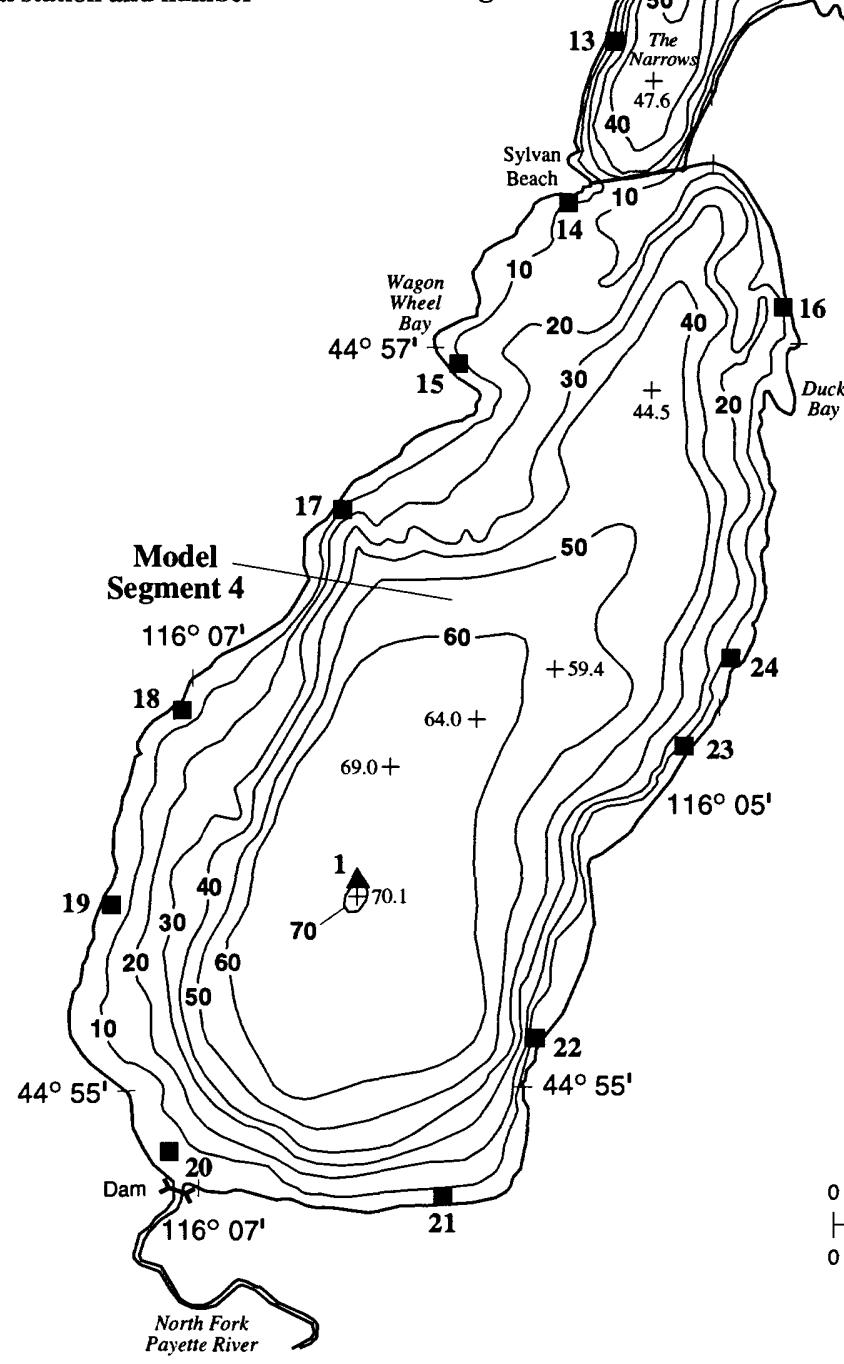

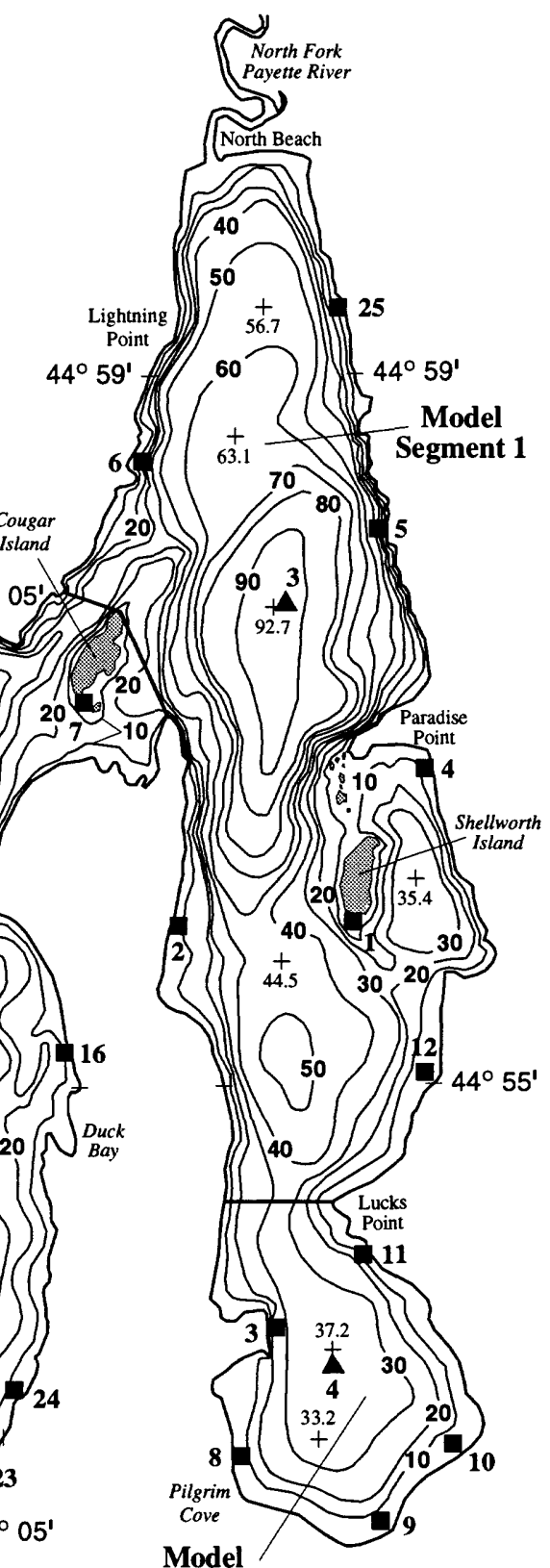

Segment 2

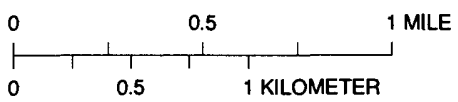

Figure 3. Locations of limnetic and littoral sampling stations and model segments, and bathymetry of Payette Lake. 


$$
P A R_{z}=P A R_{i}\left(e^{-n z}\right) P S,
$$

where

$P A R_{z}$ is $P A R$ input to artificial substrate during incubation, in Einsteins per square meter;

$P A R_{i}$ is $P A R$ input to lake surface during incubation, in Einsteins per square meter;

$e$ is base of natural logarithms, unitless;

$n$ is extinction coefficient of nearest limnetic station, per meter;

$z$ is depth of artificial substrate, in meters; and

$P S$ is decimal percent of station shaded.

Immediately following retrieval of the ceramic balls, the attached periphyton were brushed gently into a $500-\mathrm{mL}$ plastic jar containing $200 \mathrm{~mL}$ of lakewater. The periphyton/lakewater sample was homogenized in a blender and three subsamples were withdrawn for filtration. The filters (Whatman GF/F glass fiber) were frozen immediately. The chlorophyll- $a$ analyses were performed using a Turner Designs fluorometer (model 10-005R) and the methods described by Koenings and others (1987). Two replicate analyses were run on the supernatant derived from an acetone extraction of each chlorophyll- $a$-bearing filter. The amount of chlorophyll- $a$ associated with the periphyton on each ceramic ball was computed with the following equation:

$$
B_{c h l}=\left[(C)\left(V_{e}\right)\left(V_{t} / V_{f}\right)(C F)\right] / A,
$$

where

$B_{c h l}$ is periphyton biomass, as chlorophyll- $a$, on artificial substrate, in milligrams per square meter;

$C$ is concentration of chlorophyll- $a$ in extract, in micrograms per liter;

$V_{e}$ is volume of extract, in liters;

$V_{t}$ is volume of periphyton/lakewater sample, in liters;

$V_{f}$ is volume of periphyton/lakewater sample, filtered, in liters;

$C F$ is factor to convert micrograms to milligrams; and

$A$ is area of artificial substrate, in square meters.

During July 1996, the 20 littoral stations equipped with artificial substrates were surveyed for occurrence and taxonomic composition of aquatic macrophytes.
The taxonomic work was performed onsite by a botanist from the Bureau of Land Management.

\section{Limnetic Zone}

\section{WATER TEMPERATURE}

Solar heating was sufficient to develop thermal stratification and thermoclines, defined as a decrease in water temperature with depth exceeding $1{ }^{\circ} \mathrm{C}$ per meter, at the four stations in both years (fig. 4). Thermoclines developed during June and continued into October. Thermocline depths ranged from about $4 \mathrm{~m}$ in June to about $10 \mathrm{~m}$ in October. Maximum water temperatures in 1995 and 1996 were measured near the surface in late July. In 1995 , the maximum was $21.1^{\circ} \mathrm{C}$ at station 1 ; in 1996 , the maximum was $20.6^{\circ} \mathrm{C}$ at station 3. Minimum water temperatures during the winter months reached $0^{\circ} \mathrm{C}$ immediately beneath the ice covering the lake surface. Hypolimnetic water temperatures ranged from about $4^{\circ} \mathrm{C}$ during ice cover to between 5 and $6^{\circ} \mathrm{C}$ near the end of thermal stratification.

\section{WATER-COLUMN TRANSPARENCY}

The two measures of water-column transparency, secchi-disc transparency and euphotic-zone depth, had a strong positive correlation $(\mathrm{r}=0.77, \mathrm{p}<0.00001, \mathrm{n}=$ 71). The smallest values for the two variables were measured during June of both years after snowmelt runoff increased turbidity in the lake (fig. 5). After June, the two variables steadily increased as suspended sediment settled. One exception to this trend was during 1996 at station 1 when both variables either decreased in depth or failed to deepen substantially. Among the four stations, station 1 had the highest density of phytoplankton; thus, its water-column transparency was reduced.

Median secchi-disc transparencies at the four stations during 1995 were equal to or less than those measured in 1996 (table 6). Median euphotic-zone depths during both years were equivalent except at station 3 . The euphotic zone typically was deeper than the thermocline at each of the four stations. Under that condition, the phytoplankton circulating within the epilimnion (mixed zone above the thermocline) remain exposed to amounts of PAR sufficient for photosynthetic production of carbon in excess of respiratory demands. 
Station 1
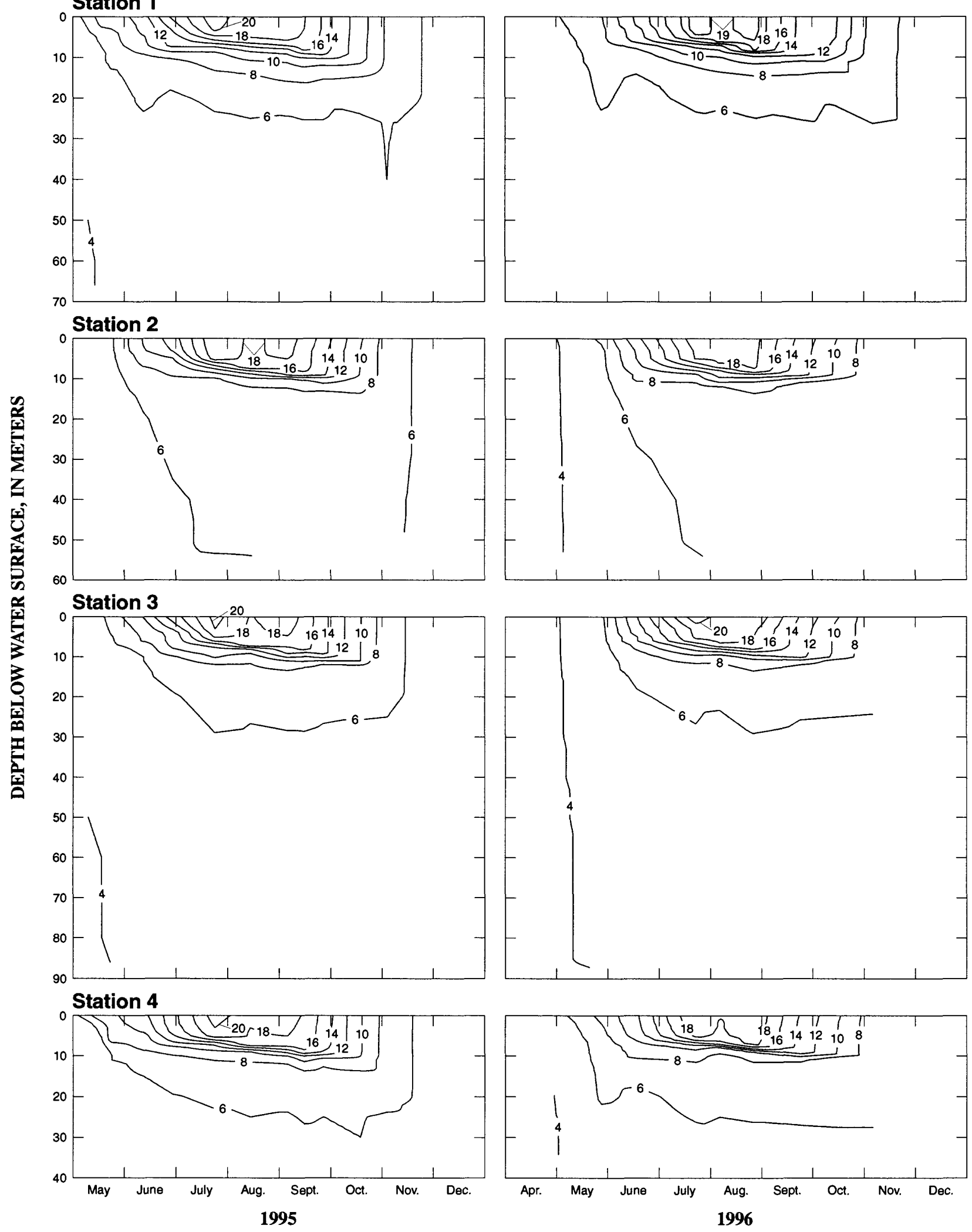

Figure 4. Lines of equal temperature, in degrees Celsius, at stations 1-4 during selected months of 1995-96, Payette Lake. 

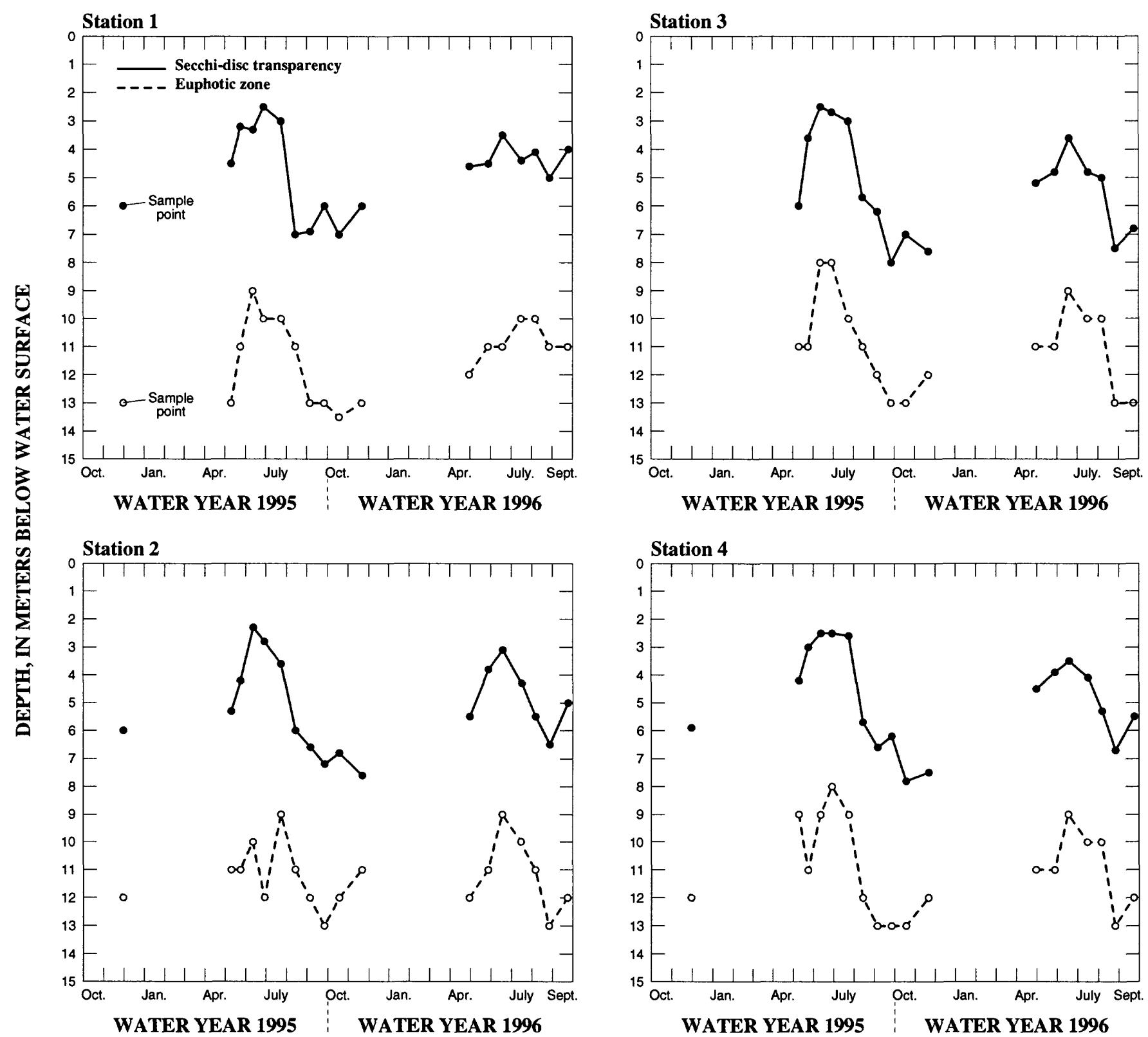

Figure 5. Depths of euphotic zone and secchi-disc transparency at stations 1-4 during 1995-96, Payette Lake.

\section{SPECIFIC CONDUCTANCE}

Specific conductance is a measure of the ability of water to conduct electricity and is typically proportional to the water's dissolved-solids concentration. For most natural waters, the ratio of dissolved-solids concentration to specific conductance ranges from 0.55 to 0.75 (Hem, 1985).
Specific conductance in Payette Lake ranged from 17 to $35 \mu \mathrm{S} / \mathrm{cm}$; most values were about $20 \mu \mathrm{S} / \mathrm{cm}$ (Brennan and others, 1996, 1997). These values are considered low for natural waters (Hem, 1985). The values greater than $30 \mu \mathrm{S} / \mathrm{cm}$ were measured in the lower hypolimnion at station 1 in conjunction with anoxic dissolved-oxygen concentrations. The lowest values were measured during June and represented the dilutional effects of snowmelt runoff. 
Table 6. Medians and ranges of secchi-disc transparency and euphotic-zone depth at four limnetic stations, 1995-96, Payette Lake

\begin{tabular}{|c|c|c|c|c|c|}
\hline \multirow{2}{*}{$\begin{array}{l}\text { Limnetic } \\
\text { station } \\
\text { (fig. 3) }\end{array}$} & \multicolumn{2}{|c|}{$\begin{array}{l}\text { Secchi-disc } \\
\text { transparency } \\
\text { (meters) }\end{array}$} & \multicolumn{2}{|c|}{$\begin{array}{c}\text { Euphotic-zone } \\
\text { depth } \\
\text { (meters) }\end{array}$} & \multirow{2}{*}{$\begin{array}{l}\text { No. of } \\
\text { samples }\end{array}$} \\
\hline & Median & Range & Median & Range & \\
\hline \multicolumn{6}{|c|}{1995} \\
\hline 1 & 4.5 & $2.5-7$ & 11 & $9-13$ & 9 \\
\hline 2 & 5.3 & $2.3-7.2$ & 11 & $9-13$ & 9 \\
\hline 3 & 4.6 & $2.5-8$ & 10.5 & $8-13$ & 8 \\
\hline 4 & 4.2 & $2.5-6.6$ & 11 & $8-13$ & 9 \\
\hline \multicolumn{6}{|c|}{1996} \\
\hline 1 & 4.5 & $3.5-7$ & 11 & $10-13$ & 9 \\
\hline 2 & 5.5 & $3.1-7.6$ & 11 & $9-13$ & 9 \\
\hline 3 & 5.2 & $3.6-7.6$ & 11 & $9-13$ & 9 \\
\hline 4 & 5.3 & $3.5-7.8$ & 11 & $9-13$ & 9 \\
\hline
\end{tabular}

\section{pH}

The variable $\mathrm{pH}$ represents the negative base- 10 logarithm of the hydrogen ion activity in moles per liter. In dilute solutions, the overall range in $\mathrm{pH}$ can be 0 to 14; values greater than 7 are considered basic and those less than 7 are considered acidic.

The overall lakewide range in $\mathrm{pH}$ was 6.2 to 8.8 (Brennan and others, 1996, 1997). The general trend in $\mathrm{pH}$ was larger values in the euphotic zone during July 1995 or August and September 1996 and smaller values in the hypolimnion during late summer and autumn. This overall pattern in $\mathrm{pH}$ fits that described for many lakes. In the summer, $\mathrm{pH}$ in the euphotic zone increases in response to photosynthetic utilization of carbon dioxide, whereas $\mathrm{pH}$ in the hypolimnion decreases as carbon dioxide is added by decomposition of organic matter.

\section{DISSOLVED OXYGEN}

The concentration of dissolved oxygen in natural freshwater is affected by temperature, barometric pressure, production of oxygen by photosynthesis, consumption of oxygen by respiration and decomposition, and mixing of water masses. The ratio (expressed as a percent) of measured dissolved-oxygen concentrations to those that would exist under saturated conditions at the same temperature and pressure is useful for comparing dissolved oxygen when significant variations in temperature and pressure exist, such as comparisons spanning time or depth.

The overall range in dissolved-oxygen concentration over depth and time at the four stations was 0 to
$11.7 \mathrm{mg} / \mathrm{L}$ in 1995 and 0 to $11.0 \mathrm{mg} / \mathrm{L}$ in 1996 (fig. 6). The maximum concentration for each year was measured at station 4 in mid-June 1995 and in late July 1996. The anoxic concentrations were measured during both years, but only in the lower hypolimnion at station 1 . The pattern within a year was that maximum dissolvedoxygen concentrations were measured within the epilimnion during the summer when photosynthetic production of oxygen exceeded oxygen consumption by respiration and decomposition. Minimum concentrations were measured in the hypolimnion during late summer and autumn when thermal stratification had reduced mixing of the oxygenated epilimnion with the hypolimnion. An important feature at station 1 was the lack of full reaeration of the water column during spring circulation. In 1995 and 1996, dissolved-oxygen concentrations in the hypolimnion at station 1 were reaerated to about $7 \mathrm{mg} / \mathrm{L}$, whereas concentrations at the other three stations were reaerated to about $10 \mathrm{mg} / \mathrm{L}$.

Stations 1 and 4 had an additional period of low dissolved-oxygen concentrations in the spring, shortly after loss of the lake's ice cover (fig. 6). In early May 1995 , both stations had hypolimnetic dissolved-oxygen concentrations as low as $4 \mathrm{mg} / \mathrm{L}$. In mid-April 1996, station 1 almost developed anoxia in its lower depths. These incidences of dissolved-oxygen minima in the spring indicate that stations 1 and 4 can have a substantial hypolimnetic dissolved-oxygen deficit under winter ice cover. One set of winter samples was collected through the ice cover at stations 1 and 4 on February 21, 1996, about midway through the 4-month period of ice cover. Dissolved-oxygen concentrations in the lower hypolimnion were 6.2 and $5.8 \mathrm{mg} / \mathrm{L}$ at stations 1 and 4 , respectively. As shown in figure 6 , dissolved-oxygen concentrations in the lower hypolimnion of station 1 continued to decline to $0.5 \mathrm{mg} / \mathrm{L}$ in mid-April; dissolved-oxygen concentrations at station $4 \mathrm{did}$ not change much until the loss of ice cover.

The overall range in percent saturation of dissolved oxygen over depth and time at the four stations was 0 to 129 percent in 1995 and 0 to 122 percent in 1996 (fig. 7). The maximum percentage for each year was measured at station 4 in mid-June 1995 and at station 1 in late July 1996. Zero percent was measured in the lower hypolimnion of station 1 during the late summer and autumn. Saturation greater than 100 percent (supersaturation) was measured in the euphotic zone of each station. During 1995, supersaturation began in May at stations 1 and 4 and in June at stations 2 and 3 and extended into October at all stations. During 1996, the 

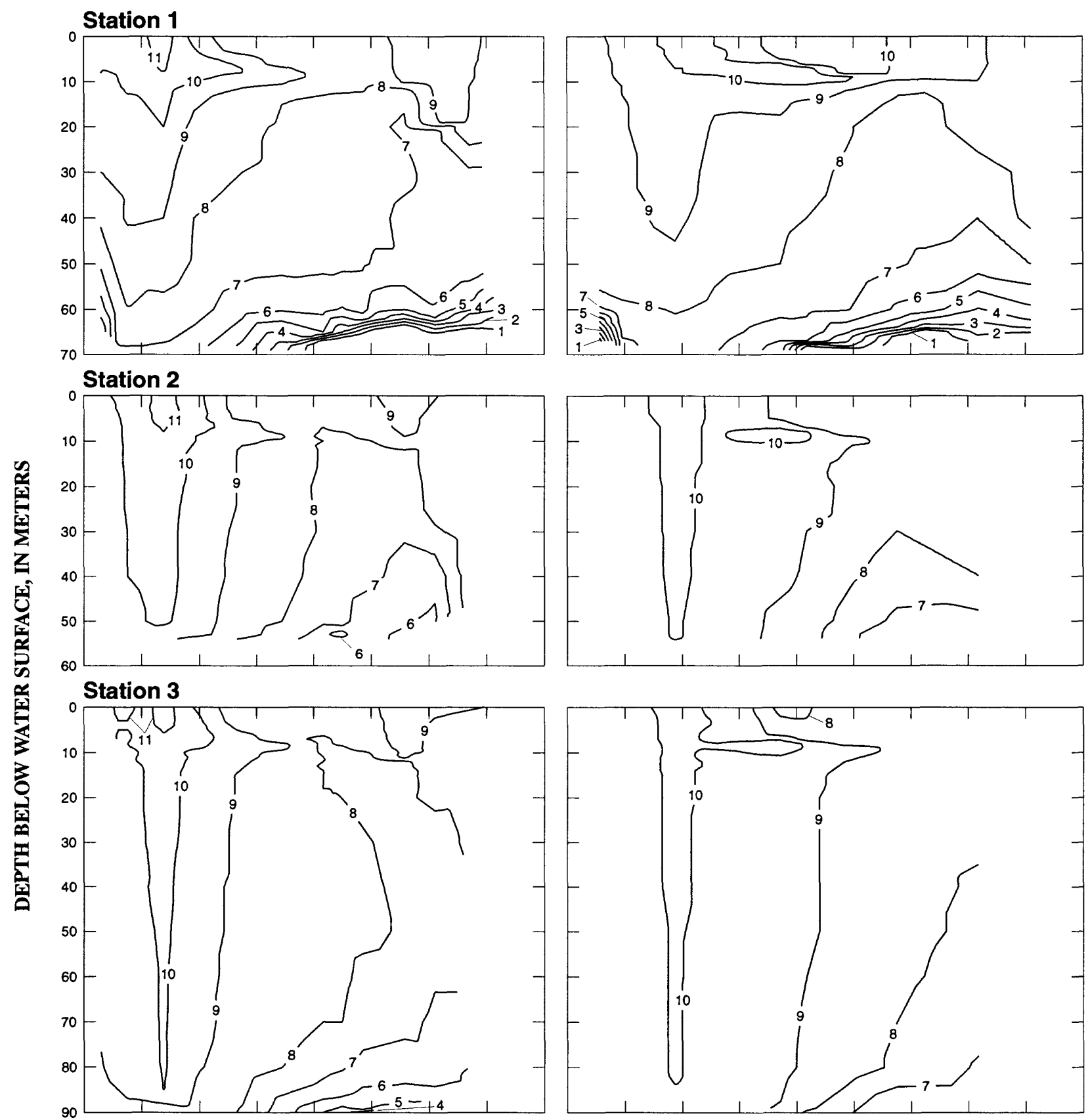

\section{Station 3}
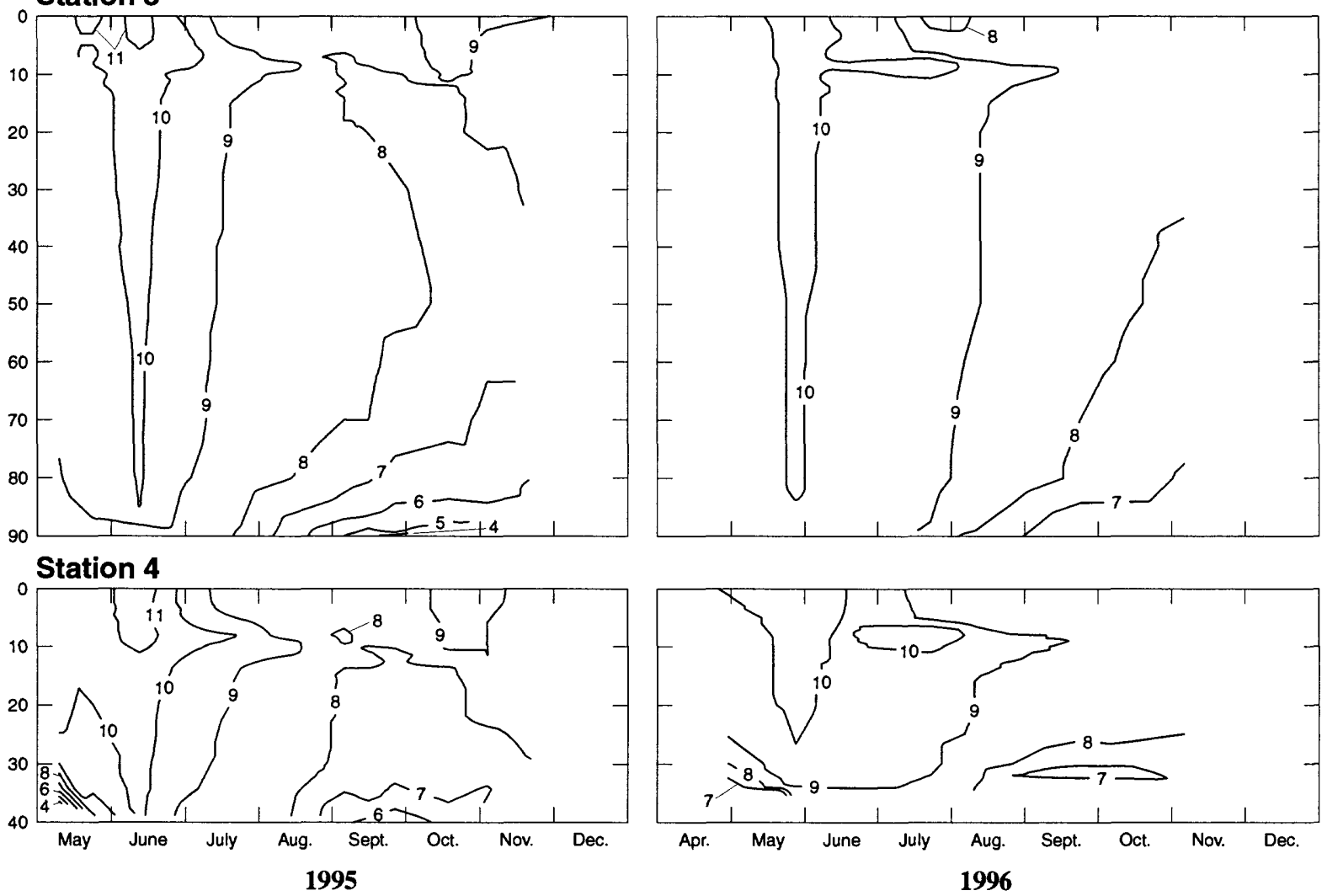

Figure 6. Lines of equal dissolved-oxygen concentration, in milligrams per liter, at stations 1-4 during selected months of 1995-96, Payette Lake. 
Station 1
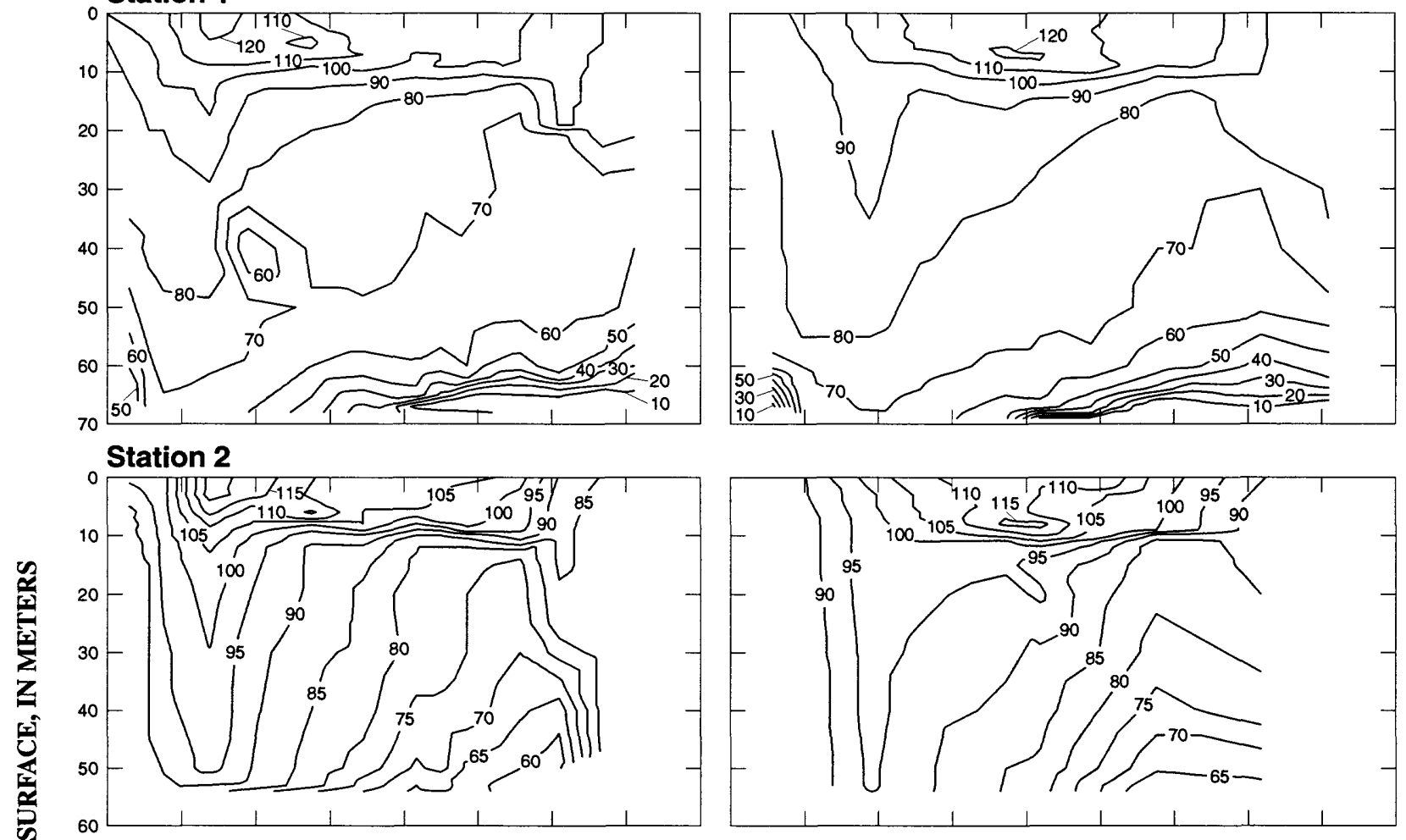

\section{Station 3}
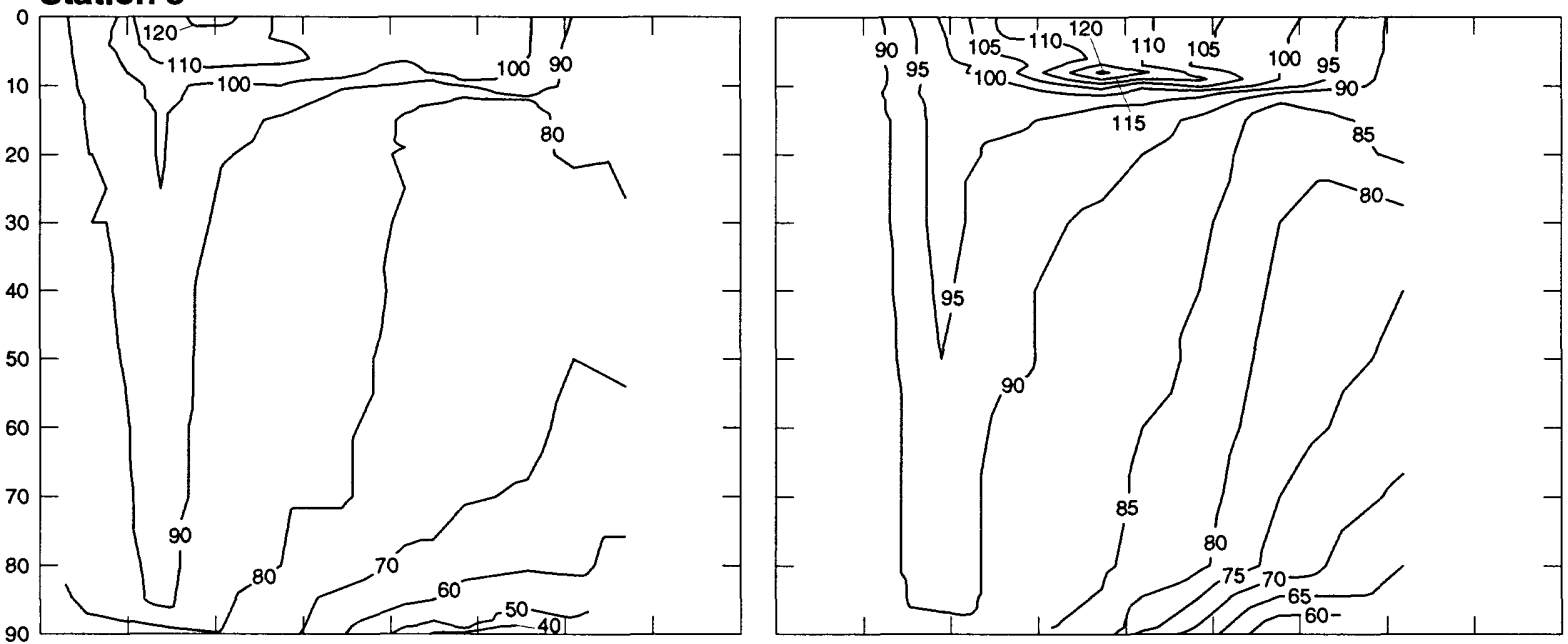

\section{Station 4}
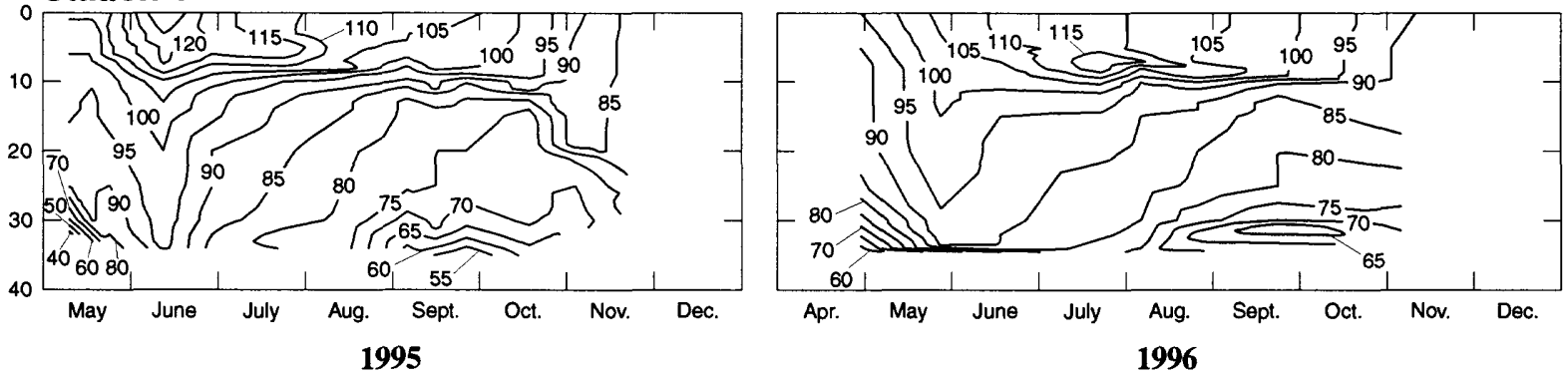

Figure 7. Lines of equal dissolved oxygen, as percent saturation, at stations 1-4 during selected months of 1995-96, Payette Lake. 
period of supersaturation at station 1 was comparable to that of 1995; however, supersaturation at the other three stations began in June and ended in August (station 4) and September (stations 2 and 3).

Depletion of dissolved oxygen within the hypolimnion of a stratified lake is an important symptom of eutrophication because it reflects the decay of organic matter produced within the euphotic zone or input to the lake by terrestrial sources. Dissolved oxygen was depleted in the hypolimnia of Payette Lake's four stations during both years; however, anoxia developed only at station 1. Accordingly, an areal hypolimnetic oxygen depletion rate (AHOD) was calculated for station 1 for each year. AHOD, in milligrams per square meter per day, is defined as the rate of decrease of dissolvedoxygen mass in the hypolimnion divided by the surface area of the hypolimnion. If AHOD is divided by the mean depth of the hypolimnion, the volumetric hypolimnetic oxygen depletion rate (VHOD) is obtained, which is the rate of decrease of the volume-weighted average dissolved-oxygen concentration in the hypolimnion.

AHOD and VHOD were calculated for Payette Lake's station 1 for both 1995 and 1996 using procedures described by Walker (1996). The calculated values represent the period from initial thermal stratification to the onset of anoxia in the hypolimnion. For 1995, this period was from June 12 to September 5; for 1996, it was from June 18 to September 24. The AHOD and VHOD for 1995 were $756\left(\mathrm{mg} / \mathrm{m}^{2}\right) / \mathrm{d}$ and $24.9\left(\mathrm{mg} / \mathrm{m}^{3}\right) / \mathrm{d}$, respectively. These values were somewhat smaller in
1996; AHOD was $451\left(\mathrm{mg} / \mathrm{m}^{2}\right) / \mathrm{d}$ and VHOD was $14.8\left(\mathrm{mg} / \mathrm{m}^{3}\right) / \mathrm{d}$.

Hutchinson (1957) used AHOD to define limits for oligotrophic and eutrophic lakes: If AHOD was less than $250\left(\mathrm{mg} / \mathrm{m}^{2}\right) / \mathrm{d}$, the lake was considered oligotrophic; if AHOD was more than $550\left(\mathrm{mg} / \mathrm{m}^{2}\right) / \mathrm{d}$, the lake was considered eutrophic. On the basis of these limits, Payette Lake would be considered eutrophic in 1995 and bordering on eutrophic in 1996. The 1981 study of Payette Lake (Falter and Mitchell, 1981) reported an AHOD for the west basin (station 1, this study) of $300\left(\mathrm{mg} / \mathrm{m}^{2}\right) / \mathrm{d}$; this result places the lake slightly above the threshold for oligotrophic but well below that for eutrophic.

\section{PHOSPHORUS}

Phosphorus is one of several essential nutrients in the metabolism of aquatic plants. Eutrophication research has focused heavily on phosphorus because it is the nutrient typically found to have the smallest supplyto-demand ratio for aquatic plant growth. Phosphorus concentrations for this study are reported as total phosphorus and dissolved orthophosphorus, as phosphorus. Total phosphorus represents the phosphorus in solution and contained in or attached to biotic and abiotic particulate material. Dissolved orthophosphorus is determined from the filtrate that passes through a filter with a nominal pore size of $0.45 \mu \mathrm{m}$. The orthophosphate ion is the most important form of phosphorus because it is directly available for metabolic use by aquatic plants.

Table 7. Medians of total phosphorus and dissolved orthophosphorus from the euphotic zone and lower hypolimnion at four limnetic stations, 1995-96, Payette Lake

[ $\mu \mathrm{g} / \mathrm{L}$, micrograms per liter; $\mathrm{n}$, number of samples]

\begin{tabular}{|c|c|c|c|c|c|c|c|c|}
\hline \multirow{3}{*}{$\begin{array}{l}\text { Limnetic } \\
\text { station } \\
\text { (fig. 3) } \\
\end{array}$} & \multicolumn{4}{|c|}{ Total phosphorus $(\mu g / L)$} & \multicolumn{4}{|c|}{ Dissolved orthophosphorus ( $\mu \mathrm{g} / \mathrm{L})$} \\
\hline & \multicolumn{2}{|c|}{ Euphotic zone } & \multicolumn{2}{|c|}{ Lower hypolimnion } & \multicolumn{2}{|c|}{ Euphotic zone } & \multicolumn{2}{|c|}{ Lower hypolimnion } \\
\hline & Median & $\mathbf{n}$ & Median & $\mathbf{n}$ & Median & $\mathbf{n}$ & Median & $\mathbf{n}$ \\
\hline \multicolumn{9}{|c|}{1995} \\
\hline 1 & 4 & 9 & 5 & 9 & 0.5 & 9 & 1 & 9 \\
\hline 2 & 4 & 9 & 4 & 8 & .5 & 9 & .5 & 8 \\
\hline 3 & 4 & 8 & 4 & 8 & .5 & 8 & 1 & 8 \\
\hline 4 & 6 & 9 & 5 & 9 & .5 & 9 & .5 & 9 \\
\hline \multicolumn{9}{|c|}{1996} \\
\hline 1 & 6.5 & 10 & 8.5 & 10 & .5 & 10 & .8 & 10 \\
\hline 2 & 6 & 9 & 5 & 9 & .5 & 9 & .5 & 9 \\
\hline 3 & 6 & 9 & 5 & 9 & .5 & 9 & .5 & 9 \\
\hline 4 & 6 & 10 & 6 & 10 & .5 & 10 & .5 & 10 \\
\hline
\end{tabular}



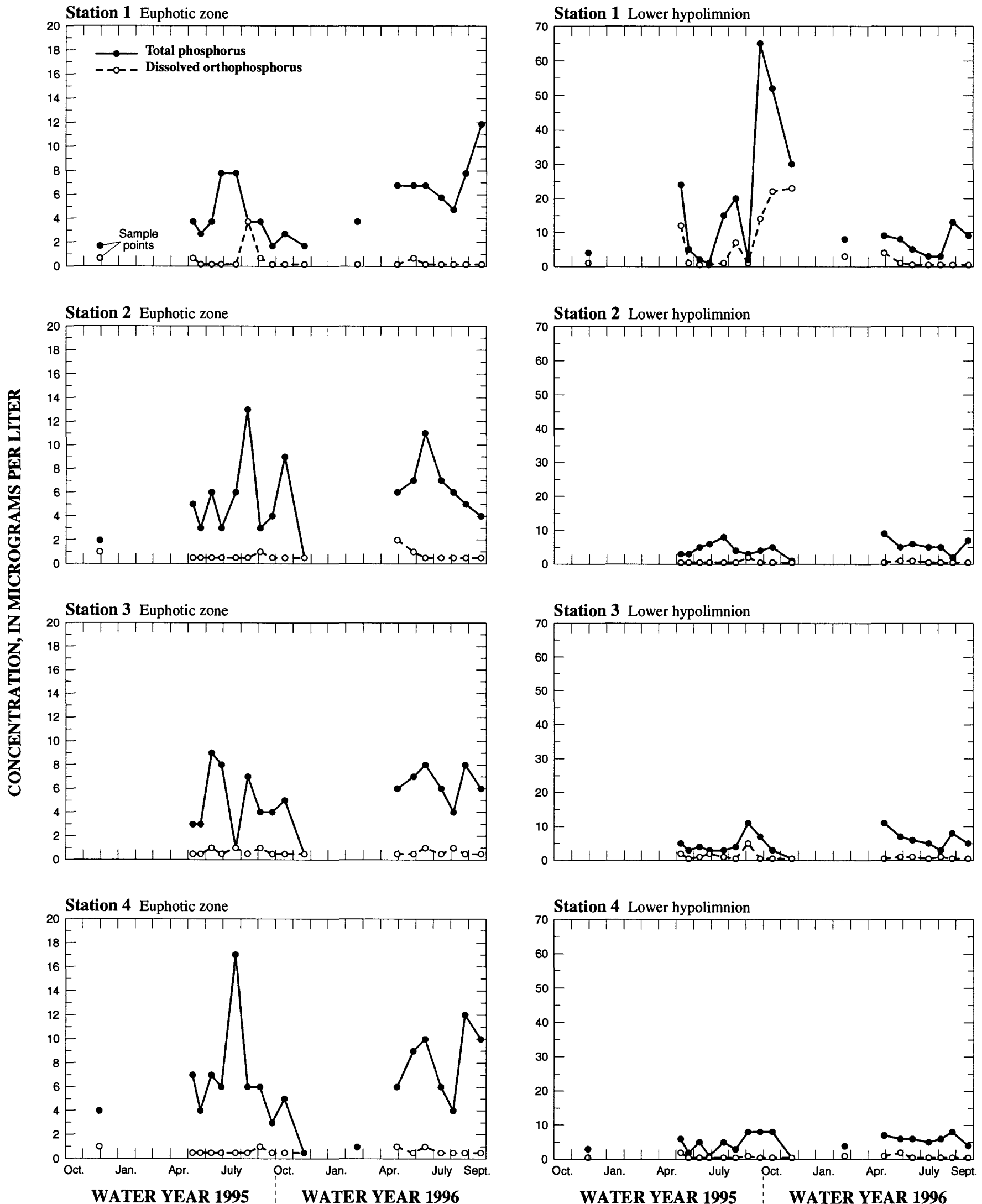

Figure 8. Concentrations of total phosphorus and dissolved orthophosphorus in the euphotic zone and lower hypolimnion at stations 1-4 during 1995-96, Payette Lake. 
Median concentrations of total phosphorus at the four stations ranged from 4 to $6.5 \mu \mathrm{g} / \mathrm{L}$ in the euphotic zone and from 4 to $8.5 \mu \mathrm{g} / \mathrm{L}$ in the lower hypolimnion; the largest median concentrations were at station 1 in 1996 (table 7). Median concentrations of total phosphorus in the euphotic zone and lower hypolimnion were slightly larger in 1996, except at station 4 . The median concentrations of dissolved orthophosphorus were 0.5 $\mu \mathrm{g} / \mathrm{L}$ in the euphotic zone at the four stations; the medians for the lower hypolimnion samples ranged from 0.5 to $1 \mu \mathrm{g} / \mathrm{L}$ (table 7).

Total phosphorus concentrations at the four stations ranged from 0.5 to $65 \mu \mathrm{g} / \mathrm{L}$ during 1995 and from 0.5 to $52 \mu \mathrm{g} / \mathrm{L}$ during 1996 , whereas dissolved orthophosphorus concentrations ranged from 0.5 to $14 \mu \mathrm{g} / \mathrm{L}$ during 1995 and from 0.5 to $23 \mu \mathrm{g} / \mathrm{L}$ during 1996 (fig. 8). The largest concentrations of both constituents were measured in the hypolimnion of station 1 from September through November 1995, when near-bottom water had become anoxic. Under anoxic conditions, constituents such as phosphorus, ammonia, iron, and manganese in the lakebed sediments are solubilized and released into the hypolimnion (Stumm and Morgan, 1970).

Phytoplanktonic uptake of dissolved orthophosphorus in the euphotic zone during the summer growing season is sometimes discerned by distinct declines in that constituent and increases in total phosphorus as the phytoplankton population converts dissolved orthophosphorus into particulate phosphorus. Such a relation was not evident in Payette Lake on the basis of the temporal patterns illustrated in figure 8 . The relation may have been masked by the very low concentrations of dissolved orthophosphorus typically measured in Payette Lake's euphotic zone.

\section{NITROGEN}

Nitrogen, like phosphorus, is essential to the metabolism of aquatic plants. The supply-to-demand ratio for nitrogen is small and, thus, nitrogen may limit the growth of aquatic plants as phosphorus does. The nitrogen cycle in aquatic ecosystems is complex because most processes involving nitrogen are biologically mediated. In aquatic ecosystems, nitrogen commonly exists in the following forms: dissolved molecular nitrogen, nitrogen-containing organic compounds, ammonia, ammonium, nitrite, and nitrate. Nitrogen concentrations for this study were analyzed as total ammonia plus organic nitrogen (commonly called kjeldahl nitrogen), dissolved ammonia, and dissolved nitrite plus nitrate, as nitrogen. Total ammonia plus organic nitrogen represents the ammonia (includes ammonium) and organic nitrogen compounds in solution and associated with biotic and abiotic particulate material. The dissolved concentrations represent the ammonia (includes ammonium) or nitrite plus nitrate in filtrate that passes through a $0.45-\mu \mathrm{m}$ filter. The following discussion is for total nitrogen (the sum of total ammonia plus organic nitrogen and dissolved nitrite plus nitrate) and dissolved inorgan-

Table 8. Medians of total nitrogen and dissolved inorganic nitrogen from the euphotic zone and lower hypolimnion at four limnetic stations, 1995-96, Payette Lake

[ $\mu \mathrm{g} / \mathrm{L}$, micrograms per liter; $\mathrm{n}$, number of samples]

\begin{tabular}{|c|c|c|c|c|c|c|c|c|}
\hline \multirow{3}{*}{$\begin{array}{l}\text { Limnetic } \\
\text { station } \\
\text { (fig. 3) }\end{array}$} & \multicolumn{4}{|c|}{ Total nitrogen $(\mu \mathrm{g} / \mathrm{L})$} & \multicolumn{4}{|c|}{ Dissolved inorganic nitrogen $(\mu g / L)$} \\
\hline & \multicolumn{2}{|c|}{ Euphotic zone } & \multicolumn{2}{|c|}{ Lower hypolimnion } & \multicolumn{2}{|c|}{ Euphotic zone } & \multicolumn{2}{|c|}{ Lower hypolimnion } \\
\hline & Median & $\overline{\mathbf{n}}$ & Median & $\mathbf{n}$ & Median & $\bar{n}$ & Median & $\mathbf{n}$ \\
\hline \multicolumn{9}{|c|}{1995} \\
\hline 1 & 158 & 9 & 197 & 9 & 28 & 9 & 84 & 9 \\
\hline 2 & 226 & 9 & 290 & 8 & 60 & 9 & 188 & 8 \\
\hline 3 & 230 & 8 & 319 & 7 & 51 & 8 & 202 & 8 \\
\hline 4 & 188 & 9 & 315 & 8 & 51 & 9 & 174 & 9 \\
\hline \multicolumn{9}{|c|}{1996} \\
\hline 1 & 244 & 10 & 304 & 10 & 102 & 10 & 180 & 10 \\
\hline 2 & 253 & 9 & 406 & 9 & 111 & 9 & 301 & 9 \\
\hline 3 & 270 & 8 & 431 & 9 & 111 & 9 & 360 & 9 \\
\hline 4 & 272 & 10 & 361 & 10 & 170 & 10 & 318 & 10 \\
\hline
\end{tabular}


Station 1 Euphotic zone
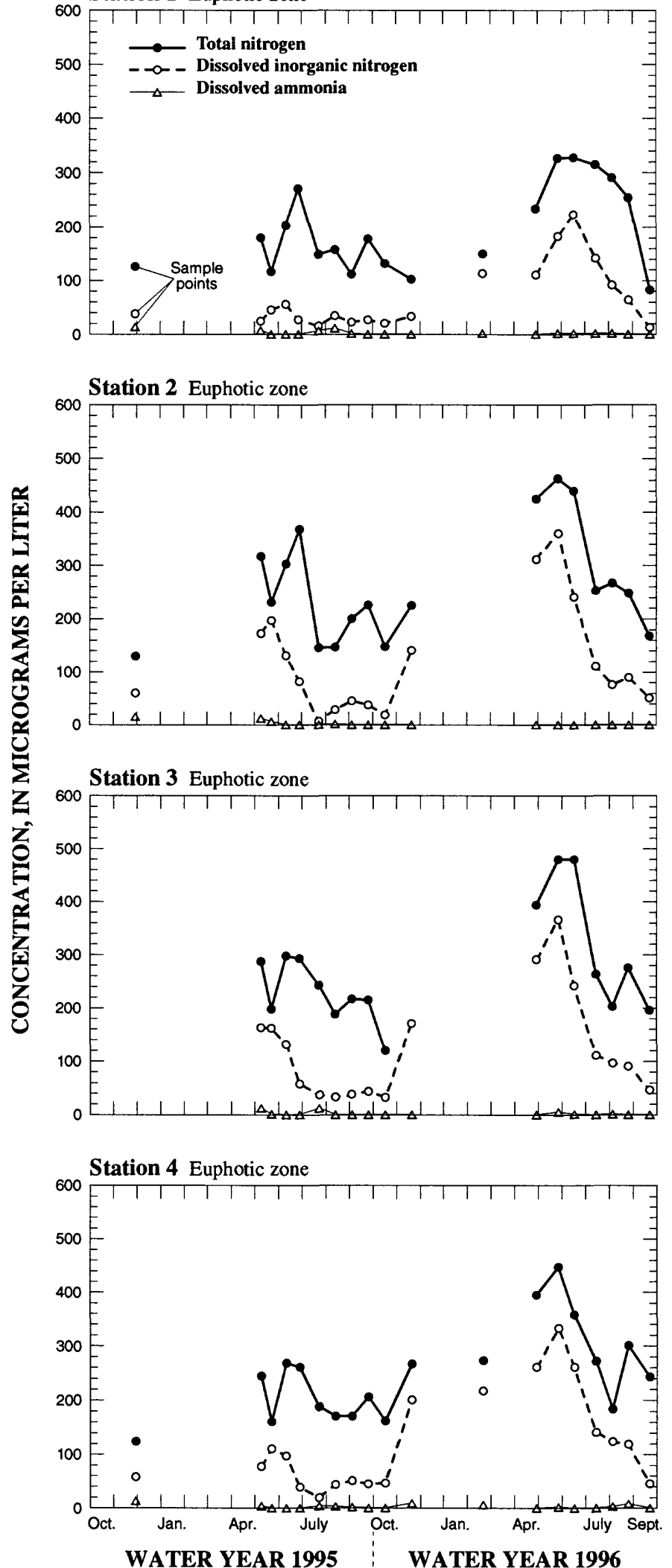

Station 1 Lower hypolimnion
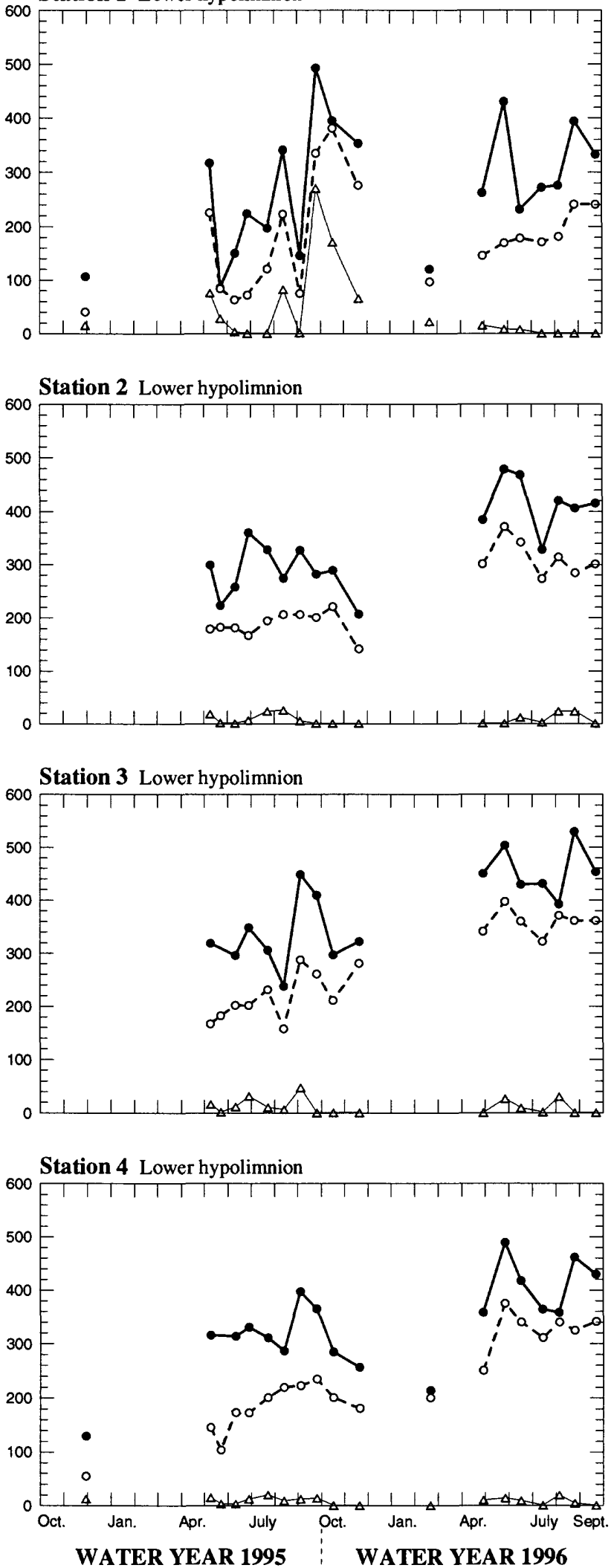

Figure 9. Concentrations of total nitrogen, dissolved inorganic nitrogen, and dissolved ammonia in the euphotic zone and lower hypolimnion at stations 1-4 during 1995-96, Payette Lake. 
ic nitrogen (the sum of dissolved ammonia and dissolved nitrite plus nitrate).

Median concentrations of total nitrogen at the four stations ranged from 158 to $272 \mu \mathrm{g} / \mathrm{L}$ in the euphotic zone and from 197 to $431 \mu \mathrm{g} / \mathrm{L}$ in the lower hypolimnion; 1996 medians were distinctly larger than those in 1995 (table 8). Median concentrations of dissolved inorganic nitrogen at the four stations ranged from 28 to $170 \mu \mathrm{g} / \mathrm{L}$ in the euphotic zone and from 84 to $360 \mu \mathrm{g} / \mathrm{L}$ in the lower hypolimnion; as with total nitrogen, 1996 medians were larger than 1995 medians (table 8). The larger median concentrations of nitrogen measured in 1996 were attributable to the larger nitrogen loads delivered to the lake in 1996.

Total nitrogen concentrations at the four stations ranged from 86 to $493 \mu \mathrm{g} / \mathrm{L}$ during 1995 and from 83 to $529 \mu \mathrm{g} / \mathrm{L}$ during 1996 (fig. 9). Dissolved inorganic nitrogen concentrations at the four stations ranged from 7 to $335 \mu \mathrm{g} / \mathrm{L}$ during 1995 and from 13 to $397 \mu \mathrm{g} / \mathrm{L}$ during 1996 (fig. 9). Lower-hypolimnion concentrations of total nitrogen and dissolved inorganic nitrogen were larger than those in the euphotic zone. The increased hypolimnetic concentrations of the two constituents reflect the settling and decomposition of organic matter from the euphotic zone into the hypolimnion. The increase in dissolved inorganic nitrogen concentrations also is indicative of nitrification in the hypolimnion, whereby, under aerobic conditions, organic and ammonia nitrogen is converted to nitrite and then nitrate. The large increase in ammonia in the lower hypolimnion of station 1 during September and October 1995 (fig. 9) reflects the release of ammonia from lakebed sediments when the hypolimnion became anoxic.

\section{LIMITING NUTRIENT}

The limiting nutrient concept of Liebig (Welch, 1980 ), in concert with the stoichiometry of the photosynthesis equation, led to formulation of nitrogen-tophosphorus ratios $(\mathrm{N}: \mathrm{P})$. These ratios have been used extensively in eutrophication studies to determine whether nitrogen or phosphorus was most likely to limit phytoplankton growth. The atomic ratio of nitrogen to phosphorus, $16 \mathrm{~N}: 1 \mathrm{P}$, in the photosynthesis equation corresponds to a mass ratio of $7.2 \mathrm{~N}: 1 \mathrm{P}$. Typically, $\mathrm{N}: \mathrm{P}$ values are calculated using the biologically available forms of these two nutrients, dissolved inorganic nitrogen and dissolved orthophosphorus. If N:P (by weight) is less than 7.2, then nitrogen may be limiting, whereas if $\mathrm{N}: \mathrm{P}$ exceeds 7.2, then phosphorus may be limiting (Ryding and Rast, 1989).

The N:P values in table 9 and figure 10 indicate phosphorus limitation of phytoplankton growth in the euphotic zone of Payette Lake. The lowest ratio, 8.8, still exceeded the threshold of 7.2. The median ratios for 1996 were higher than those for 1995 . This difference resulted from the higher concentrations of dissolved inorganic nitrogen measured in 1996 because dissolved orthophosphorus concentrations were nearly equal in both years.

\section{CHLOROPHYLL-a}

Chlorophyll- $a$ is the primary photosynthetic pigment of phytoplankton and, as such, is used as an estimator of phytoplanktonic biomass. Median concentrations of chlorophyll- $a$ at Payette Lake's four stations ranged from 1.6 to $2.4 \mu \mathrm{g} / \mathrm{L}$ during 1995 and from 0.8 to $1.3 \mu \mathrm{g} / \mathrm{L}$ during 1996 (table 10). The 1995 median was highest at station 4, whereas the 1996 median was highest at station 1 . The overall range in concentrations was from 0.2 to $5.2 \mu \mathrm{g} / \mathrm{L}$; the largest concentration was at station 1 in 1995 (table 10). Chlorophyll- $a$ concentrations at the four stations had a distinct peak during June 1995; concentrations generally declined over the remainder of the year except for an autumn increase at station 1 (fig. 11). The seasonal pattern during 1996 was more muted; concentrations generally increased from late April through September.

Table 9. Medians and ranges of ratios of dissolved inorganic nitrogen to dissolved orthophosphorus from the euphotic zone at four limnetic stations, 1995-96, Payette Lake

\begin{tabular}{cccc}
\hline \multirow{2}{*}{$\begin{array}{c}\text { Limnetic station } \\
\text { (fig. 3) }\end{array}$} & \multicolumn{2}{c}{ Ratio } & $\begin{array}{c}\text { No. of } \\
\text { samples }\end{array}$ \\
\cline { 2 - 3 } & Median & Range & \\
1 & 1995 & & 9 \\
2 & 38 & $8.8-112$ & 9 \\
3 & 76 & $14-394$ & 8 \\
4 & 102 & $38-326$ & 9 \\
& 88 & $40-222$ & \\
1 & 1996 & & 10 \\
2 & 180 & $26-440$ & 9 \\
3 & 180 & $38-480$ & 9 \\
4 & 222 & $66-732$ & 10 \\
\hline
\end{tabular}




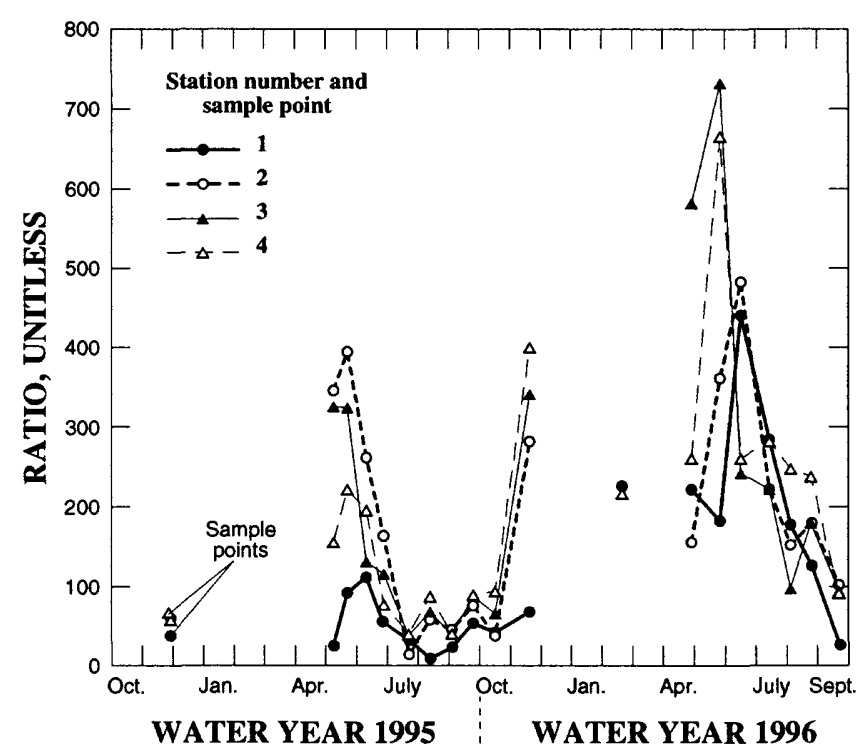

Figure 10. Ratios of dissolved inorganic nitrogen to dissolved orthophosphorus at stations 1-4 during 1995-96, Payette Lake.

\section{PHYTOPLANKTON}

Phytoplankton collected at the four stations during 1995-96 comprised five phyla (Chlorophyta, or green algae; Chrysophyta, or yellow-brown algae; Cryptophyta, or cryptomonads; Cyanophyta, or bluegreen algae; and Pyrrhophyta, or dinoflagellates), 44 genera, and 67 species (table 11). The taxonomic

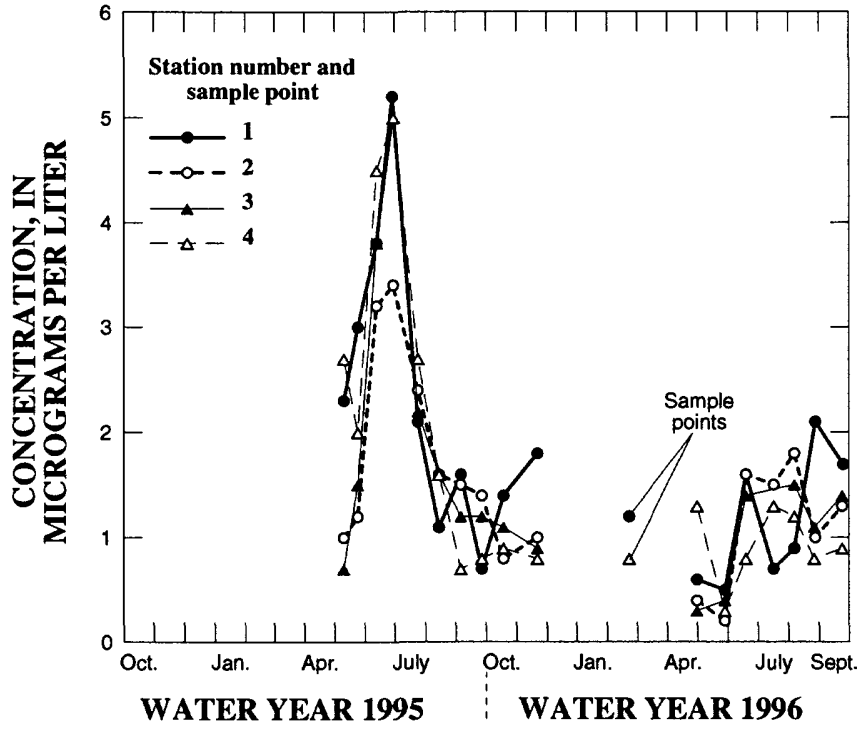

Figure 11. Chlorophyll-a concentrations at stations 1-4 during 1995-96, Payette Lake.

composition was strongly dominated by the subphylum Bacillariophyceae, or diatoms. The Cyanophyta, represented by Anacystis marina and Chroococcus minimus, were a very minor component of the phytoplankton in both years.

Lakewide, median density and biovolume for the 64 samples were 663 cells $/ \mathrm{mL}$ and $384,000 \mu \mathrm{m}^{3} / \mathrm{mL}$, respectively. Among the four stations, median biovolume

Table 10. Medians and ranges of chlorophyll-a concentrations and phytoplankton biovolumes from the euphotic zone at four limnetic stations, 1995-96, Payette Lake

$\left[\mu \mathrm{g} / \mathrm{L}\right.$, micrograms per liter; $\mu \mathrm{m}^{3} / \mathrm{mL}$, cubic micrometers per milliliter; $\mathbf{n}$, number of samples]

\begin{tabular}{|c|c|c|c|c|c|c|}
\hline \multirow{2}{*}{$\begin{array}{l}\text { Limnetic } \\
\text { station } \\
\text { (fig. 3) }\end{array}$} & \multicolumn{3}{|c|}{$\begin{array}{c}\text { Chlorophyll-a } \\
\text { concentration } \\
(\mu g / L)\end{array}$} & \multicolumn{3}{|c|}{$\begin{array}{l}\text { Phytoplankton biovolume } \\
\qquad\left(\mu \mathrm{m}^{3} / \mathrm{mL}\right)\end{array}$} \\
\hline & Median & Range & $\mathbf{n}$ & Median & Range & $\mathbf{n}$ \\
\hline \multicolumn{7}{|c|}{1995} \\
\hline 1 & 2.2 & $0.7-5.2$ & 8 & 962,000 & $70,000-2,770,000$ & 7 \\
\hline 2 & 1.6 & $1.0-3.4$ & 8 & 426,000 & $189,000-2,520,000$ & 7 \\
\hline 3 & 1.6 & $.7-5$ & 8 & 420,000 & $97,100-2,820,000$ & 7 \\
\hline 4 & 2.4 & $.7-5$ & 8 & 774,000 & $109,000-2,840,000$ & 7 \\
\hline \multicolumn{7}{|c|}{1996} \\
\hline 1 & 1.3 & $.5-2.1$ & 10 & 556,000 & $313,000-1,890,000$ & 9 \\
\hline 2 & 1.0 & $.2-1.8$ & 9 & 184,000 & $88,200-923,000$ & 9 \\
\hline 3 & 1.1 & $.3-1.5$ & 8 & 189,000 & $81,900-1,700,000$ & 9 \\
\hline 4 & .8 & $.3-1.3$ & 10 & 230,000 & $76,600-2,340,000$ & 9 \\
\hline
\end{tabular}


Table 11. Phytoplankton taxa at four limnetic stations, 1995-96, Payette Lake

\begin{tabular}{|c|c|c|}
\hline Phytoplankton taxa ${ }^{1}$ & Phytoplankton taxa ${ }^{1}$ & Phytoplankton taxa' \\
\hline 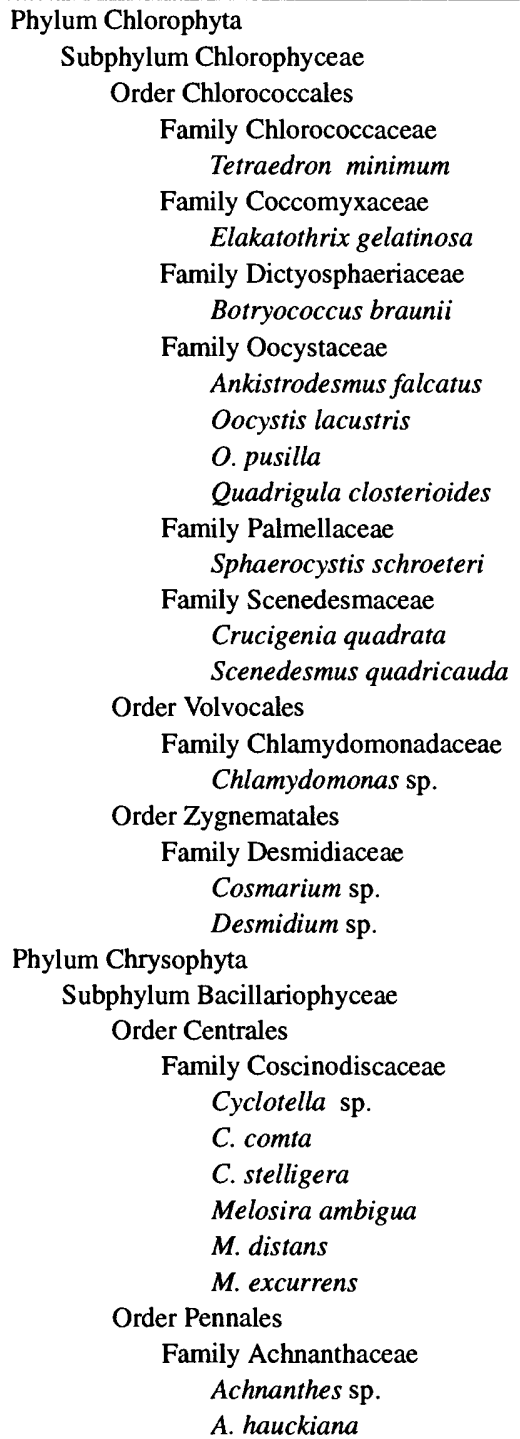 & 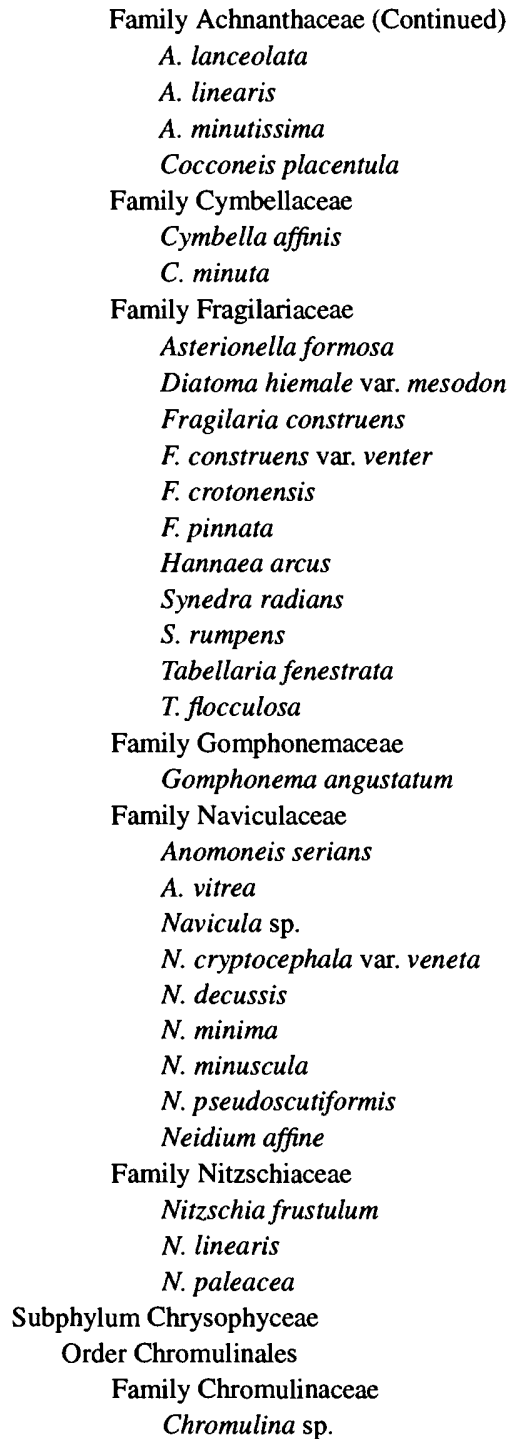 & $\begin{array}{c}\text { Family Chromulinaceae (Continued) } \\
\text { Kephyrion sp. } \\
\text { K. littorale } \\
\text { K. spirale } \\
\text { Family Chrysococcaceae } \\
\text { Chrysococcus rufescens } \\
\text { Family Pedinellaceae } \\
\text { Pseudopedinella sp. } \\
\text { Order Ochromonadales } \\
\text { Family Dinobryaceae } \\
\text { Dinobryon sertularia } \\
\text { Family Ochromonadaceae } \\
\text { Ochromonas sp. } \\
\text { Family Synuraceae } \\
\text { Mallomonas sp. } \\
\text { Order Prymnesiales } \\
\text { Family Prymnesiaceae } \\
\text { Chrysochromulina sp. } \\
\text { Phylum Cryptophyta } \\
\text { Family Cryptochrysidaceae } \\
\text { Rhodomonas minuta } \\
\text { Family Cryptomonadaceae } \\
\text { Cryptomonas erosa } \\
\text { Fhylum Pyrrhophyta } \\
\text { Class Dinophyceae } \\
\text { Order Dinokontae } \\
\text { Family Ceratiaceae } \\
\text { Ceratium hirundinella } \\
\text { Family Glenodiniaceae } \\
\text { Glenodinium sp. } \\
\text { Feridinium cinctum }\end{array}$ \\
\hline
\end{tabular}

\footnotetext{
${ }^{1}$ Taxonomy based on Prescott (1970).
}

was highest at station 1 in 1995 and 1996 (table 10). Biovolume peaked in July of both years; only station 1 had a substantial secondary peak in the autumn of both years (fig. 12). Biovolume was dominated by one diatom, Tabellaria fenestrata, which, on average, contributed 52 percent of the lakewide biovolume.

\section{TROPHIC STATE}

The biological productivity, or trophic state, of a lake is commonly categorized into one of three trophic states: oligotrophic (low productivity), eutrophic (high productivity), and mesotrophic (moderate productivity). Numerous variables have been used as the basis for trophic-state classification; some of the most frequently encountered are total phosphorus, total nitrogen, chlorophyll- $a$, and secchi-disc transparency. These four variables were used by Ryding and Rast (1989) to develop an open-boundary trophic-state classification system, which compensates for the overlap in classification that commonly occurs with a fixed-boundary system. Under the open-boundary system, a lake is considered correctly classified if three of the four classification 


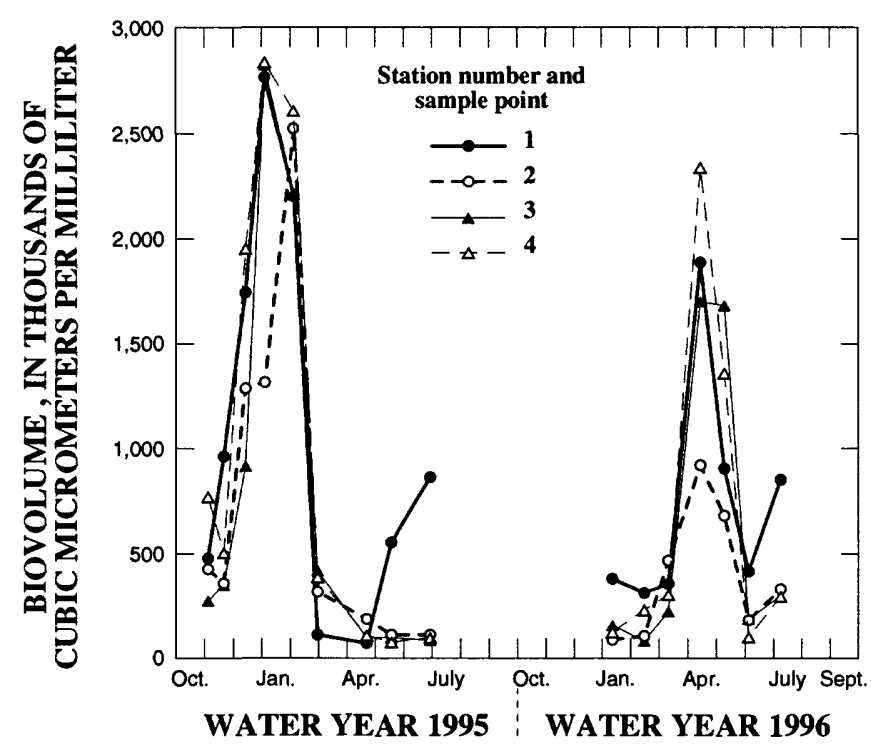

Figure 12. Phytoplankton biovolume at stations $1-4$ during 1995-96, Payette Lake.

variables are within 2 standard deviations of their geometric mean for the same trophic state.

Annual geometric means for euphotic-zone values of total phosphorus, total nitrogen, chlorophyll- $a$, and secchi-disc transparency were computed for Payette Lake for comparison with the open-boundary trophic-state classification system (table 12). The lake was classified as oligotrophic in both years on the basis of total phosphorus, total nitrogen, and chlorophyll- $a$. On the basis of secchi-disc transparency, the lake was mesotrophic in both years.

Three earlier studies also classified the trophic state of Payette Lake. During the late 1970's, the lake was classified as oligotrophic on the basis of chemical and biological variables (Idaho Department of Health, 1970). The National Eutrophication Survey of 1975 classified the lake as early mesotrophic (U.S. Environmental Protection Agency, 1977). Falter (1984) used areal phosphorus loading as his basis for classifying the lake as mesotrophic in the early 1980's. These three studies indicate an increasing trend in trophic state; however, the trend may be misleading because the basis for trophic-state classification was not consistent among the three studies.

\section{SEDIMENT NUTRIENTS}

Concentrations of total phosphorus and total nitrogen in lakebed sediments at the four stations ranged from 1,400 to $4,800 \mathrm{mg} / \mathrm{kg}$ and 720 to $920 \mathrm{mg} / \mathrm{kg}$, respectively (table 13). The highest concentration of total phosphorus was at station 1 , whereas the highest concentration of total nitrogen was at station 4 .

Guidelines have been published for assessing the potential effects of trace elements and nutrients in aquatic sediments on benthic organisms (Persaud and others, 1993). The guidelines include three levels of effect: no effect, lowest effect, and severe effect. The low-

Table 12. Trophic state of Payette Lake during 1995-96 based on annual geometric mean values for four limnological variables

[ $\mu \mathrm{g} / \mathrm{L}$, micrograms per liter; m, meters; O, oligotrophic; M, mesotrophic; E, eutrophic]

\begin{tabular}{|c|c|c|c|c|c|c|c|}
\hline \multirow{2}{*}{$\begin{array}{l}\text { Limnological } \\
\text { variable }\end{array}$} & \multirow[b]{2}{*}{ Statistic $^{1}$} & \multicolumn{3}{|c|}{ Open-boundary } & \multicolumn{3}{|c|}{ Payette Lake ${ }^{3}$} \\
\hline & & 0 & $\mathbf{M}$ & $\mathbf{E}$ & 1995 & 1996 & $1995-96$ \\
\hline $\begin{array}{l}\text { Total phosphorus } \\
\qquad(\mu \mathrm{g} / \mathrm{L})\end{array}$ & $\begin{array}{c}\bar{\chi} \\
\bar{\chi} \pm 1 \mathrm{SD}\end{array}$ & $\begin{array}{c}8.0 \\
4.8-13.3\end{array}$ & $\begin{array}{c}26.7 \\
14.5-49.0\end{array}$ & $\begin{array}{c}84.4 \\
48.0-189.0\end{array}$ & $\begin{array}{c}4.5 \\
2.0-6.8\end{array}$ & $\begin{array}{c}4.9 \\
0.9-8.9\end{array}$ & $\begin{array}{c}4.7 \\
1.4-8.0\end{array}$ \\
\hline $\begin{array}{l}\text { Total nitrogen } \\
\quad(\mu \mathrm{g} / \mathrm{L})\end{array}$ & $\begin{array}{c}\bar{\chi} \\
\bar{\chi} \pm 1 \mathrm{SD}\end{array}$ & $\begin{array}{c}661 \\
371-1,180\end{array}$ & $\begin{array}{c}753 \\
485-1,170\end{array}$ & $\begin{array}{c}1,875 \\
861-4,081\end{array}$ & $\begin{array}{c}199 \\
137-261\end{array}$ & $\begin{array}{c}252 \\
141-363\end{array}$ & $\begin{array}{c}225 \\
135-315\end{array}$ \\
\hline $\begin{array}{l}\text { Chlorophyll- } a \\
\quad(\mu \mathrm{g} / \mathrm{L})\end{array}$ & $\begin{array}{c}\bar{\chi} \\
\bar{\chi} \pm 1 \mathrm{SD}\end{array}$ & $\begin{array}{c}1.7 \\
0.8-3.4\end{array}$ & $\begin{array}{c}4.7 \\
3.0-7.4\end{array}$ & $\begin{array}{c}14.3 \\
6.7-31.0\end{array}$ & $\begin{array}{c}1.9 \\
0.8-3.0\end{array}$ & $\begin{array}{c}0.9 \\
0.4-1.4\end{array}$ & $\begin{array}{c}1.3 \\
0.4-2.2\end{array}$ \\
\hline $\begin{array}{l}\text { Secchi-disc } \\
\text { transparency } \\
\text { (m) }\end{array}$ & $\begin{array}{c}\bar{\chi} \\
\bar{\chi} \pm 1 \mathrm{SD}\end{array}$ & $\begin{array}{c}9.9 \\
5.9-16.5\end{array}$ & $\begin{array}{c}4.2 \\
2.4-7.4\end{array}$ & $\begin{array}{c}2.4 \\
1.5-4.0\end{array}$ & $\begin{array}{c}4.3 \\
2.6-6.0\end{array}$ & $\begin{array}{c}5.2 \\
3.8-6.6\end{array}$ & $\begin{array}{c}4.7 \\
3.1-6.3\end{array}$ \\
\hline
\end{tabular}


est effect level signifies sediment contamination that can be tolerated by most benthic organisms, whereas the severe effect level signifies polluted sediment that will significantly affect benthic organisms. For total phosphorus, the lowest and severe effect levels are 600 and $2,000 \mathrm{mg} / \mathrm{kg}$, respectively. For total nitrogen, the lowest and severe effect levels are 550 and $4,800 \mathrm{mg} / \mathrm{kg}$, respectively. Total phosphorus concentrations at station 1 clearly exceeded the severe effect level and, at station 3, nearly met that level. Total nitrogen concentrations at all four stations were well below the severe effect level (table 13).

\section{Littoral Zone}

\section{PERIPHYTON PRODUCTION}

Periphyton production in the littoral zone of Payette Lake was assessed to determine whether a statistical relation existed between periphyton production and various indices of nearshore development. The indices for each littoral station included housing density, percentage of lawn area, relative age of development, relative level of disturbance of natural soils and vegetation, and lake subbasin. The hypothesis was that stations with little or no disturbance of natural conditions would have low levels of periphyton production, whereas increased levels of disturbance would produce increased nutrient loads which would stimulate periphyton production.

Median periphyton production, as chlorophyll- $a$, at the 19 (artificial substrate from one station was lost) littoral stations ranged from 0.38 (station 12) to 12.9 (station 22) $\mathrm{mg} / \mathrm{m}^{2}$, a difference of 33.9 times (table 14). When normalized to PAR input, the median production

Table 13. Concentrations of total phosphorus and total nitrogen in lakebed sediments at four limnetic stations, July 1996 , Payette Lake

[m, meters; $\mathrm{mg} / \mathrm{kg}$, milligrams per kilogram]

\begin{tabular}{cccc}
\hline & & \multicolumn{2}{c}{$\begin{array}{c}\text { Concentration } \\
(\mathbf{m g} / \mathbf{k g})\end{array}$} \\
\cline { 3 - 4 } $\begin{array}{c}\text { Limnetic station } \\
\text { (fig. 3) }\end{array}$ & $\begin{array}{c}\text { Water } \\
\text { depth }\end{array}$ & $\begin{array}{c}\text { Total } \\
\text { phosphorus }\end{array}$ & $\begin{array}{c}\text { Total } \\
\text { nitrogen }\end{array}$ \\
\hline 1 & 68 & 4,800 & 720 \\
2 & 55 & 1,400 & 910 \\
3 & 90 & 1,900 & 740 \\
4 & 34 & 1,400 & 920 \\
\hline
\end{tabular}

Table 14. Periphyton production, as chlorophyll-a, at 19 littoral stations, July-August 1996, Payette Lake

[PAR, photosynthetically active radiation; E, Einstein; $\mathrm{mg} / \mathrm{m}^{2}$, milligrams per square meter; $\left(\mathrm{mg} / \mathrm{m}^{2}\right) / \mathrm{E}$, milligrams per square meter per Einstein]

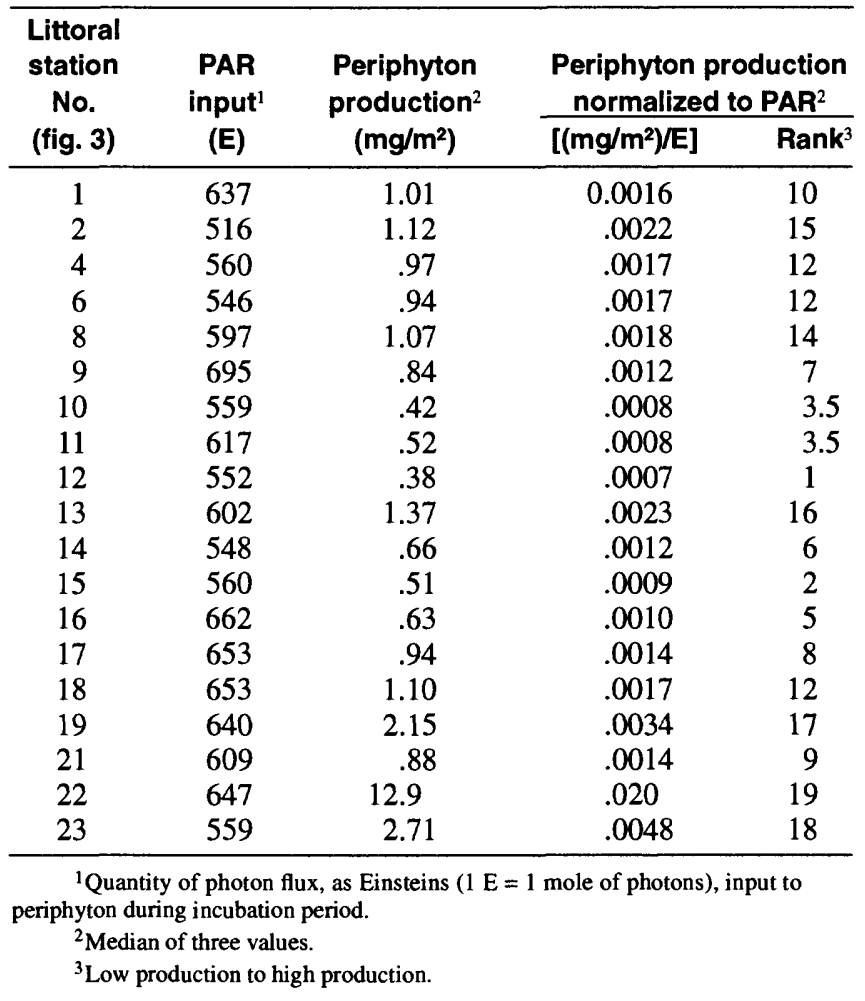

ranged from 0.0007 (station 12) to 0.02 (station 22) $\left(\mathrm{mg} / \mathrm{m}^{2}\right) / \mathrm{E}$, a difference of 28.6 times. For both comparisons, production was lowest at station 12 and highest at station 22. The nearshore development at station 12 included a very large home surrounded by an extensive lawn area. At station 22, new construction of several large homes had disturbed most of the soil and vegetative cover. This station is also at the former site of a lumber mill. On the basis of ranks, PAR-normalized periphyton production at stations 10,11 , and 15 was the lowest of any in the lake, even though nearshore development at these three stations was substantial. Conversely, production at stations 1,2 , and 4 , all undisturbed, was some of the highest of any in the lake.

Multiple linear regression (Helsel and Hirsch, 1992) was used to investigate the relation between PAR-normalized periphyton production and the five indices of nearshore development. Periphyton production was normalized with PAR to remove its influence from the predictive equation. Scatterplots and a correlation matrix indicated little, if any, relation between PAR- 
normalized periphyton production and any of the indices of nearshore development. This observation was confirmed with the regression analyses. When the five indices were included in the model, they explained 41 percent of the variation in the dependent variable; however, the $\mathrm{p}$-value for the $\mathrm{F}$ statistic was 0.175 , indicating no relation. Of the five partial-regression coefficients, only relative level of disturbance was significant, with a p-value of 0.033 .

The absence of a strong relation between periphyton production and selected indices of nearshore development at Payette Lake was similar to results of a recent study at Priest Lake reported by Rothrock and Mosier (1996). Periphyton production, as chlorophyll- $a$, was measured on natural substrates at 21 nearshore locations during the summers of 1994-95 in Priest Lake, a $95-\mathrm{km}^{2}$ oligotrophic lake in northern Idaho. Periphyton production in Priest Lake showed no strong relation with any of the following variables: site aspect, bank slope, fetch distance, developed versus undeveloped nearshore, and interstitial nutrient concentrations.

\section{AQUATIC MACROPHYTES}

Nine genera of aquatic macrophytes were collected at 19 littoral stations during July 1996 (table 15). Isoetes lacustris and Myriophyllum spicatum var. exalbescens were the dominant genera, collected at 16 and 13 of the stations, respectively. Nitella sp. and Ranunculus aquatilis were collected at 8 of the stations. Chara sp. was collected only at station 14 . Diversity was highest at stations 11,16 , and 17 , where five genera were collected, and was lowest at station 15 , where no aquatic macrophytes were collected. Of particular interest was the discovery of $M$. spicatum var. spicatum at stations 21 and 22, which are adjacent to the city boat ramp. This plant, whose common name is Eurasian milfoil, is considered a nuisance because it grows aggressively, can propagate by fragmentation, and is extremely difficult to eradicate. The occurrence of Eurasian milfoil near the boat ramp suggests that it was introduced to Payette Lake from a boat or boat trailer that had been used in a lake infested with the plant.

An earlier survey of aquatic macrophytes at six locations in Payette Lake was conducted in July and September 1981 by Falter and Mitchell (1981). The 1981 taxonomic composition was similar to that of the current study, but only six genera were collected and $P$. robbinsii was the dominant genera. Eurasian milfoil was not reported in the 1981 study.
Table 15. Aquatic macrophyte taxa at 19 littoral stations, July 1996, Payette Lake

\begin{tabular}{|c|c|}
\hline Aquatic macrophyte taxa ${ }^{1}$ & Littoral station No. \\
\hline \multicolumn{2}{|l|}{ Phylum Chlorophyta } \\
\hline \multicolumn{2}{|l|}{ Family Characeae } \\
\hline Chara sp............ & 14 \\
\hline Nitella sp. .......... & $1,2,4,5,11,12,16,23$ \\
\hline \multicolumn{2}{|l|}{ Phylum Pteridophyta } \\
\hline \multicolumn{2}{|l|}{ Family Isoetaceae } \\
\hline Isoetes lacustris & $\begin{array}{c}1,2,4,5,6,8,10,11,12,13 \\
14,16,17,19,21,23\end{array}$ \\
\hline \multicolumn{2}{|l|}{ Phylum Spermatophyta } \\
\hline \multicolumn{2}{|l|}{ Class Angiospermae } \\
\hline \multicolumn{2}{|l|}{ Family Haloragaceae } \\
\hline \multicolumn{2}{|l|}{ Myriophyllum spicatum } \\
\hline var. exalbescens ..... & $\begin{array}{l}4,6,8,9,10,11,12,13,14 \\
16,17,18,23\end{array}$ \\
\hline \multicolumn{2}{|l|}{ M. spicatum } \\
\hline var. spicatum . . . . . . . . & 21,22 \\
\hline \multicolumn{2}{|l|}{ Family Hydrocharitaceae } \\
\hline Elodea canadensis . . . . . . . & $6,11,13,16,17,18,22$ \\
\hline \multicolumn{2}{|l|}{ Family Naiadaceae } \\
\hline Potamogeton robbinsii ..... & $4,5,11,17,23$ \\
\hline P. zosteriformis $\ldots \ldots \ldots$ & $6,11,19$ \\
\hline \multicolumn{2}{|l|}{ Family Ranunculaceae } \\
\hline Ranunculus aquatilis ...... & $8,9,13,16,17,18,19,22$ \\
\hline
\end{tabular}

\footnotetext{
${ }^{1}$ Taxonomy based on Prescott (1969) and Steward and others (1963).
}

\section{Effects of Fire on Lake Water Quality}

The effects of the 1994 forest fires on Payette Lake's water quality were evaluated on the basis of data collected by IDEQ at four limnetic stations during July, September, and October 1992 and August and September 1993 (D. Worth, Idaho Division of Environmental Quality, written commun., September 1995). IDEQ data for chlorophyll- $a$, nutrients, and dissolved oxygen were compared with USGS data collected during similar time periods in 1995 and 1996.

Hydrologically, lake outflow during the 1992 water year was 49 percent of the long-term mean; during the 1993 water year, lake outflow was 106 percent of the long-term mean. Thus, the water-residence time in 1992 was 4.8 years, or about twice normal; in 1993, it was 2.2 years, or about normal. Water-residence times in the 1995 and 1996 water years were 1.84 and 1.42 years, respectively, or shorter than normal. The limnological basis for the comparison of residence times is that longer 
residence times are expected to enhance a lake's biological production because nutrients and phytoplankton are retained longer in the lake.

If the effects of the 1994 forest fires in this comparison are disregarded, Payette Lake would have been expected to be most productive in 1992, the year with the longest water-residence time. However, post-fire chlorophyll- $a$ concentrations were about double those measured in the 2 years prior to the fires, even though post-fire water-residence times were much less than normal. Chlorophyll- $a$ concentrations in the 1992 samples ranged from 0.2 to $1.15 \mu \mathrm{g} / \mathrm{L}$ and the median was $0.71 \mu \mathrm{g} / \mathrm{L}$. The 1993 chlorophyll- $a$ concentrations ranged from 0.5 to $1.0 \mu \mathrm{g} / \mathrm{L}$ and the median was $0.65 \mu \mathrm{g} / \mathrm{L}$. For a similar period in 1995, chlorophyll- $a$ concentrations ranged from 0.7 to $2.7 \mu \mathrm{g} / \mathrm{L}$ and the median was $1.4 \mu \mathrm{g} / \mathrm{L}$; in 1996 , the range was from 0.8 to $2.1 \mu \mathrm{g} / \mathrm{L}$ and the median was $1.3 \mu \mathrm{g} / \mathrm{L}$.

Payette Lake received substantially larger loads of nitrogen during 1995-96 as a result of the 1994 forest fires. Phosphorus loads also increased substantially in 1995, largely because of loads from Fall Creek. A comparison of in-lake nutrient concentrations indicated that post-fire concentrations of nitrogen were much larger than pre-fire concentrations, whereas post-fire phosphorus concentrations were smaller. During August and September 1993, median concentrations of dissolved inorganic nitrogen, total phosphorus, and dissolved orthophosphorus were $12,10.5$, and $10 \mu \mathrm{g} / \mathrm{L}$, respectively, in the upper water column and 122, 23, and $11 \mu \mathrm{g} / \mathrm{L}$, respectively, in the lower hypolimnion. During similar periods in 1995-96, median concentrations of dissolved inorganic nitrogen, total phosphorus, and dissolved orthophosphorus were 50,5 , and $0.5 \mu \mathrm{g} / \mathrm{L}$, respectively, in the upper water column and 251,5 , and $0.5 \mu \mathrm{g} / \mathrm{L}$, respectively, in the lower hypolimnion. The twofold to fourfold increase in dissolved inorganic nitrogen is reasonable in that this constituent is soluble and is not readily adsorbed to particulate material, which may settle rapidly after introduction to the lake. In contrast, the absence of a large post-fire increase in phosphorus may be due to its ready adsorption to particulate material.

Dissolved-oxygen concentrations also were measured by IDEQ in 1992 and 1993; however, the profiled depths often were not measured in the deepest parts of the four basins. Thus, the assessment of pre- and postfire development of the hypolimnetic dissolved-oxygen deficit in the southwest basin (limnetic station 1, this study) is incomplete. The most valid comparison is for late July 1992, when a dissolved-oxygen concentration of $2.8 \mathrm{mg} / \mathrm{L}$ was measured at the $71-\mathrm{m}$ depth in the southwest basin. Dissolved-oxygen concentrations at this location at similar depths and times during 1995 and 1996 were 2.6 and $1.0 \mathrm{mg} / \mathrm{L}$, respectively. On the basis of this comparison, the effects of fire on the hypolimnetic dissolved-oxygen deficit were undetectable.

\section{NUTRIENT LOAD/LAKE RESPONSE MODEL}

\section{Model Description}

The empirical nutrient load/lake response model (Walker, 1996) applied to Payette Lake provided a mathematical method for simulating the lake's limnological responses to alterations in hydrologic and nutrient loads delivered to the lake from various sources. The model combined data on the lake's morphometrics, hydrologic and nutrient budgets, and limnological characteristics to simulate the following eutrophication-related variables: concentrations of total phosphorus, total nitrogen, and chlorophyll- $a$; secchi-disc transparency; and hypolimnetic dissolved-oxygen deficit.

Three programs, FLUX, PROFILE, and BATHTUB, composed the model. The FLUX program quantifies tributary loads of water and nutrients using a variety of calculation methods. The PROFILE program generates statistical summaries of water-quality conditions in the water body within a temporal and spatial context. The BATHTUB program applies nutrient-balance and eutrophication-response models within a spatially segmented hydraulic framework that accounts for advection, diffusion, and sedimentation. BATHTUB is a highly evolved version of empirical lake-eutrophication models and incorporates additional variables to account for important processes such as nonlinear nutrient-sedimentation kinetics, inflow nutrient partitioning, seasonal and spatial variations, and algal growth limitation by factors such as phosphorus, nitrogen, light, and flushing rate. If error estimates are provided for input variables, BATHTUB can express output variables in probabilistic terms. An important feature of BATHTUB is the ability for modeling linked segments of the lake to account for spatial variations in water quality. Segment boundaries can be selected on the basis of factors such as lake morphometry, important sources of water and nutrients, and lake hydrodynamics. 
Table 16. Characteristics of the four segments of Payette Lake modeled by BATHTUB

[ $\mathrm{km}^{2}$, square kilometers; $\mathrm{km}^{3}$, cubic kilometers; $\mathrm{m}$, meters]

\begin{tabular}{|c|c|c|c|c|}
\hline \multirow{2}{*}{$\begin{array}{l}\text { Characteristics } \\
\text { and units }\end{array}$} & \multicolumn{4}{|c|}{ Segment (fig. 3) } \\
\hline & 1 & 2 & 3 & 4 \\
\hline Surface area, $\mathrm{km}^{2}$. & 6.51 & 1.69 & 1.37 & 10.9 \\
\hline Volume, $\mathbf{k m}^{3} \ldots$ & .279 & .035 & .038 & .402 \\
\hline Mean depth, $m \ldots \ldots \ldots$ & 42.9 & 20.7 & 27.7 & 36.9 \\
\hline Maximum depth, $m \ldots$. & 92.7 & 37.2 & 55.5 & 70.1 \\
\hline Segment weight ${ }^{1} \ldots \ldots \ldots$ & .32 & .08 & .07 & .53 \\
\hline $\begin{array}{l}\text { Important tributary } \\
\text { inflow source.... }\end{array}$ & $\begin{array}{l}\text { North Fork } \\
\text { Payette River }\end{array}$ & None & None & None \\
\hline $\begin{array}{l}\text { Outflow routed to } \\
\text { segment number }\end{array}$ & on & 1 & 4 & Outlet \\
\hline $\begin{array}{l}\text { Limnetic station } \\
\quad \text { for segment .... }\end{array}$ & 3 & 4 & 2 & 1 \\
\hline
\end{tabular}

${ }^{1}$ Based on surface area of segment divided by surface area of lake.

Payette Lake was divided into four segments (fig. 3); each segment's characteristics are listed in table 16. Segment 1 is the deep, northeastern basin; it covers $6.5 \mathrm{~km}^{2}$ and contains $0.28 \mathrm{~km}^{3}$. This segment receives the lake's primary inflow from the North Fork Payette River. Segment 2 is the southeastern basin; it covers $1.7 \mathrm{~km}^{2}$ and contains $0.04 \mathrm{~km}^{3}$. This segment is the most hydrologically isolated from the primary inflow and is farthest from the lake's outflow. Segment 3 is the smallest basin and connects the northeastern and southwestern basins. This segment covers $1.4 \mathrm{~km}^{2}$ and contains $0.04 \mathrm{~km}^{3}$. Segment 4 is the southwestern basin and contains the lake's outlet into the North Fork Payette River. This segment has the largest area and volume, $10.9 \mathrm{~km}^{2}$ and $0.4 \mathrm{~km}^{3}$.

Water-quality characteristics for each segment were input to BATHTUB. The characteristics were computed with PROFILE using data from the four limnetic stations. Except for the hypolimnetic dissolvedoxygen deficit, the characteristics represented mean annual values for the euphotic zone for water years 1995 and 1996. The euphotic zone was the primary focus for modeling because most of the empirical relations used by BATHTUB were derived from studies of euphotic zones.

The hydrologic and nutrient budgets (tables 3-5) were the source of water and nutrient loads input to BATHTUB. Each segment received water and nutrient loads from the subbasins draining into it. If a subbasin contributed to more than one segment, its water and nutrient loads were apportioned between the segments on the basis of drainage area.

\section{Model Calibration and Verification}

The model was calibrated with 1996 data using a selection of submodels discussed in the user manual (Walker, 1996, table 4.2). The submodels for phosphorus and nitrogen sedimentation were based on secondorder decay rates; the chlorophyll- $a$ submodel was based on phosphorus, light, and flushing rate; and the secchi-disc transparency submodel was based on chlorophyll- $a$ and turbidity. The dispersion submodel was numerically based as shown by Fischer and others (1979). The submodels for calibration of nitrogen and phosphorus applied calibration factors to sedimentation rates, not concentrations. The initial calibration with submodels was adequate for most variables; however, several variables required calibration coefficients to achieve a satisfactory fit between observed and estimated conditions. The calibration coefficient was 0.625 for chlorophyll- $a$ and was 3.0 for the hypolimnetic dissolved-oxygen deficit.

Model calibration results for each segment and the area-weighted, lakewide mean values are summarized in table 17. Lakewide, the ratios between observed and estimated values for total phosphorus, total nitrogen, chlorophyll- $a$, and secchi-disc transparency were $1.11,1.08,1.01$, and 1.00 , respectively. In model segment 4 , the ratio between the observed and estimated hypolimnetic dissolved-oxygen deficit was 1.12.

The model was verified with 1995 data and the submodels used in the calibration; the results are summarized in table 17. Lakewide, the ratios between observed and estimated values for total phosphorus, total nitrogen, chlorophyll- $a$, and secchi-disc transparency were $0.33,0.70,0.77$, and 1.07 , respectively. In model segment 4 , the ratio between the observed and estimated hypolimnetic dissolved-oxygen deficit was 1.19.

The comparison of observed and estimated mean values is not the only criterion by which to judge the model's performance. The model output displays the mean value, plus or minus 1 standard error for each observed and estimated value. These statistical estimates are computed on the basis of errors associated with the model, as well as errors associated with each input variable. The presence or absence of overlap in the standard errors for each variable and segment is listed in table 18. For the calibration, the standard errors for all variables overlap in each segment and lakewide. For the verification, the standard errors do not overlap as follows: total phosphorus, all segments and lakewide; total nitrogen, segments 1, 4, and lakewide; chlorophyll- $a$, segment 1 . 
Table 17. Results of model calibration with 1996 data and model verification with 1995 data, Payette Lake

[TP, total phosphorus, in micrograms per liter; TN, total nitrogen, in micrograms per liter; CHL, chlorophyll- $a$, in micrograms per liter; SD, secchi-disc transparency, in meters; VHOD, volumetric hypolimnetic dissolved-oxygen deficit, in milligrams per cubic meters per day]

\begin{tabular}{|c|c|c|c|c|c|c|c|}
\hline \multirow{3}{*}{$\begin{array}{c}\text { Segment } \\
\text { (fig. 3) }\end{array}$} & \multirow[b]{3}{*}{ Variable } & \multicolumn{3}{|c|}{ Calibration } & \multicolumn{3}{|c|}{ Verification } \\
\hline & & \multicolumn{2}{|c|}{ Mean value } & \multirow{2}{*}{$\begin{array}{l}\text { Ratio of } \\
\text { observed to } \\
\text { estimated } \\
\text { value }\end{array}$} & \multicolumn{2}{|c|}{ Mean value } & \multirow{2}{*}{$\begin{array}{c}\text { Ratio of } \\
\text { observed to } \\
\text { estimated } \\
\text { value }\end{array}$} \\
\hline & & Observed & Estimated & & Observed & Estimated & \\
\hline \multirow[t]{4}{*}{1} & TP & 6.4 & 7.3 & 0.88 & 4.4 & 18.8 & 0.23 \\
\hline & TN & 328 & 319 & 1.03 & 229 & 326 & .70 \\
\hline & CHL & 1.0 & 1.3 & .79 & 1.9 & 4.0 & .47 \\
\hline & SD & 5.4 & 5.2 & 1.04 & 5.2 & 4.1 & 1.27 \\
\hline \multirow[t]{4}{*}{2} & TP & 8.1 & 6.9 & 1.17 & 6.2 & 13.4 & .46 \\
\hline & $\mathrm{TN}$ & 314 & 270 & 1.16 & 210 & 278 & .76 \\
\hline & CHL & .9 & 1.2 & .75 & 2.2 & 2.7 & .82 \\
\hline & SD & 4.8 & 4.6 & 1.04 & 4.9 & 4.6 & 1.06 \\
\hline \multirow[t]{4}{*}{3} & $\mathrm{TP}$ & 6.6 & 6.4 & 1.02 & 5.3 & 14.1 & .37 \\
\hline & TN & 323 & 276 & 1.17 & 231 & 278 & .83 \\
\hline & CHL & 1.1 & 1.1 & 1.00 & 1.8 & 2.9 & .63 \\
\hline & SD & 4.8 & 4.8 & 1.00 & 5.2 & 4.6 & 1.14 \\
\hline \multirow[t]{5}{*}{4} & $\mathrm{TP}$ & 7.4 & 5.8 & 1.28 & 4.2 & 10.5 & .40 \\
\hline & $\mathrm{TN}$ & 262 & 239 & 1.10 & 160 & 237 & .68 \\
\hline & CHL & 1.2 & 1.0 & 1.24 & 2.3 & 2.0 & 1.15 \\
\hline & SD & 4.3 & 4.4 & .97 & 4.9 & 5.1 & .96 \\
\hline & VHOD & 14.8 & 13.2 & 1.12 & 24.9 & 21.0 & 1.19 \\
\hline \multirow[t]{4}{*}{ Lakewide } & $\mathrm{TP}$ & 7.1 & 6.4 & 1.11 & 4.5 & 13.7 & .33 \\
\hline & TN & 291 & 270 & 1.08 & 191 & 272 & .70 \\
\hline & CHL & 1.1 & 1.1 & 1.01 & 2.1 & 2.8 & .77 \\
\hline & SD & 4.7 & 4.7 & 1.00 & 5.0 & 4.7 & 1.07 \\
\hline
\end{tabular}

The lack of overlap for total phosphorus is largely attributable to the unusually large, but transient, load delivered by Fall Creek to the lake during May 1995. To test the effect of Fall Creek on the model verification, the 1995 total phosphorus load from Fall Creek was adjusted to levels equivalent to those delivered by Fall Creek in 1996. With this adjustment, the standard errors for total phosphorus overlapped in all segments.

\section{Simulation Results}

A wide variety of simulations was possible owing to the complexity of Payette Lake and its drainage basin, as well as to a diverse assortment of nutrient-load alterations that could be proposed and evaluated. Simulations of nutrient-load alterations were achieved by decreasing or increasing nutrient concentrations in inflows to the lake. The water volume delivered by the inflow source was not altered because nutrient-management scenarios were assumed to affect concentrations, not flows. Limnological responses to the nutrient-load alterations were simulated with the 1996 data. The magnitudes of the responses were evaluated by comparison with the 1996 conditions estimated by the model. The output format of the simulations allowed evaluation of

Table 18. Presence or absence of overlap in standard errors for observed and estimated values of five limnological variables for calibration and verification model runs, Payette Lake

[LW, lakewide; Y, overlap present; N, overlap absent; - , not measured]

\begin{tabular}{|c|c|c|c|c|c|c|c|c|c|c|}
\hline \multirow[b]{3}{*}{ Variable } & \multicolumn{5}{|c|}{ Calibration } & \multicolumn{5}{|c|}{ Verification } \\
\hline & \multicolumn{5}{|c|}{$\begin{array}{c}\text { Segment No. } \\
\text { (fig. 3) }\end{array}$} & \multicolumn{5}{|c|}{$\begin{array}{l}\text { Segment No. } \\
\text { (fig. 3) }\end{array}$} \\
\hline & $\overline{1}$ & 2 & 3 & 4 & $\overline{L W}$ & $\overline{1}$ & 2 & 3 & 4 & LW \\
\hline Total phosphorus. . & $\mathbf{Y}$ & $\mathrm{Y}$ & $Y$ & $\mathrm{Y}$ & $\mathrm{Y}$ & $\mathbf{N}$ & $\mathbf{N}$ & $\mathbf{N}$ & $\mathbf{N}$ & $\mathbf{N}$ \\
\hline Total nitrogen ..... & $\mathrm{Y}$ & $\mathrm{Y}$ & $\mathrm{Y}$ & $\mathrm{Y}$ & $\mathrm{Y}$ & $\mathrm{N}$ & $\mathrm{Y}$ & $\mathrm{Y}$ & $\mathbf{N}$ & $\mathbf{N}$ \\
\hline Chlorophyll- $a \ldots \ldots$ & $\mathrm{Y}$ & $\mathrm{Y}$ & $\mathrm{Y}$ & $\mathrm{Y}$ & $\mathrm{Y}$ & $\mathrm{N}$ & $\mathrm{Y}$ & $\mathrm{Y}$ & $\mathrm{Y}$ & $\mathrm{Y}$ \\
\hline \multirow{4}{*}{$\begin{array}{l}\text { Secchi-disc } \\
\text { transparency.... } \\
\text { Hypolimnetic } \\
\text { dissolved-oxygen } \\
\text { deficit . . . . . . . }\end{array}$} & & & & & & & & & & \\
\hline & $\mathrm{Y}$ & $\mathrm{Y}$ & $\mathrm{Y}$ & $\mathbf{Y}$ & $\mathrm{Y}$ & $\mathrm{Y}$ & $\mathrm{Y}$ & $\mathrm{Y}$ & $\mathrm{Y}$ & $\mathrm{Y}$ \\
\hline & & & & & & & & & & \\
\hline & - & - & 一 & $\mathbf{Y}$ & 一 & - & - & - & $\mathrm{Y}$ & - \\
\hline
\end{tabular}


Table 19. Simulation 1: Limnological response to estimated phosphorus and nitrogen loads delivered to Payette Lake prior to 1994 forest fires

$\left[\mu \mathrm{g} / \mathrm{L}\right.$, micrograms per liter; $\mathrm{m}$, meters; $\left(\mathrm{mg} / \mathrm{m}^{3}\right) / \mathrm{d}$, milligrams per cubic meters per day; - , not measured]

\begin{tabular}{|c|c|c|c|c|c|c|c|c|c|c|}
\hline \multirow{2}{*}{$\begin{array}{c}\text { Segment } \\
\text { (fig. 3) }\end{array}$} & \multicolumn{2}{|c|}{$\begin{array}{c}\text { Total } \\
\text { phosphorus } \\
(\mu g / L)\end{array}$} & \multicolumn{2}{|c|}{$\begin{array}{c}\text { Total } \\
\text { nitrogen } \\
(\mu g / L)\end{array}$} & \multicolumn{2}{|c|}{$\begin{array}{c}\text { Chlorophyll-a } \\
(\mu g / L)\end{array}$} & \multicolumn{2}{|c|}{$\begin{array}{c}\text { Secchi-disc } \\
\text { transparency } \\
(\mathbf{m})\end{array}$} & \multicolumn{2}{|c|}{$\begin{array}{c}\text { Hypolimnetic } \\
\text { dissolved- } \\
\text { oxygen } \\
\text { deficit } \\
{\left[\left(\mathrm{mg} / \mathrm{m}^{3}\right) \mathrm{d}\right]}\end{array}$} \\
\hline & 1996 & Response & 1996 & Response & 1996 & Response & 1996 & Response & $\overline{1996}$ & Response \\
\hline 1 & 7.3 & 7.1 & 319 & 138 & 1.3 & 1.2 & 5.2 & 5.2 & - & - \\
\hline 2 & 6.9 & 7.1 & 270 & 129 & 1.2 & 1.3 & 4.6 & 4.6 & - & - \\
\hline 3 & 6.4 & 6.5 & 276 & 128 & 1.1 & 1.1 & 4.8 & 4.8 & - & - \\
\hline 4 & 5.8 & 6.1 & 239 & 120 & 1.0 & 1.0 & 4.4 & 4.4 & 13.2 & 13.3 \\
\hline Lakewide & 6.4 & 6.5 & 270 & 127 & 1.1 & 1.1 & 4.7 & 4.7 & - & - \\
\hline
\end{tabular}

changes in the mean value of each response variable, either within a segment or on an area-weighted, lakewide basis.

Simulation 1 estimated limnological conditions prior to the 1994 forest fires. Concentrations of total phosphorus, dissolved orthophosphorus, total nitrogen, and dissolved inorganic nitrogen in tributaries affected by the 1994 fires were scaled back to pre-fire concentrations. For the North Fork Payette River inflow, pre-fire concentrations were those measured in the $1975 \mathrm{Na}$ tional Eutrophication Survey of Payette Lake (U.S. Environmental Protection Agency, 1977). For Fall Creek and Box/Lemah Creeks, nitrogen and phosphorus concentrations were set equal to those for Dead Horse Creek in 1996. On a lakewide basis, concentrations of total phosphorus increased from 6.4 to $6.5 \mu \mathrm{g} / \mathrm{L}$ and total nitrogen decreased from 270 to $127 \mu \mathrm{g} / \mathrm{L}$ (table 19). Chlorophyll- $a$ and secchi-disc transparency were unchanged. The hypolimnetic dissolved-oxygen deficit in model segment 4 increased about 1 percent. The largest change was in total nitrogen concentrations because the primary effect of the 1994 fires on Payette Lake was the large increase in nitrogen loads. Because the lake's phytoplankton production is strongly limited by phosphorus, not nitrogen, there was little reduction in chlorophyll- $a$ concentrations and, consequently, little change in secchi-disc transparency and hypolimnetic dissolvedoxygen deficit. The large reduction in nitrogen concentrations did not shift the lake's phytoplankton production from phosphorus to nitrogen limitation.

Simulation 2 took the opposite approach to simulation 1: The half of the watershed not burned in the 1994 fires was assumed to be burned with a severity similar to that of the 1994 fires. Total nitrogen and dissolved inorganic nitrogen concentrations were increased by a factor of 2.5 for the North Fork Payette River inflow, Fall Creek, and Box/Lemah Creeks. The smaller multiplier for these three tributaries was used because about one-half of their watersheds were burned in the 1994 fires. Nitrogen was increased by a factor of 5 on Copet, Dead Horse, and Sylvan Creeks. Total phosphorus and dissolved orthophosphorus concentrations for the six tributaries were increased by a factor of 1.5 to simulate increased soil erosion. On a lakewide basis, concentrations of total phosphorus, total nitrogen, and chlorophyll- $a$ increased from 6.4 to $8.4 \mu \mathrm{g} / \mathrm{L}, 270$ to $476 \mu \mathrm{g} / \mathrm{L}$, and 1.1 to $1.5 \mu \mathrm{g} / \mathrm{L}$, respectively; secchi-disc transparency declined from 4.7 to $4.5 \mathrm{~m}$ (table 20 ). The hypolimnetic dissolved-oxygen deficit in model segment 4 increased 19 percent. The in-lake increases in total nitrogen concentrations were the most noticeable effect; smaller increases in total phosphorus concentrations helped increase chlorophyll- $a$ concentrations and the hypolimnetic dissolved-oxygen deficit; increased chlorophyll- $a$ caused a decline in secchi-disc transparency.

Simulation 3 used the responses to simulated prefire nutrient concentrations (simulation 1, table 19) as the basis for assessing the lake's response to reductions in nutrient loads from developed shoreline areas. An assumption was made that substantive nutrient-management actions would not occur until after the limnological effects of the 1994 fires had been muted by natural recovery processes in the watershed and the lake. Accordingly, concentrations of total phosphorus, dissolved orthophosphorus, total nitrogen, and dissolved inorganic nitrogen were reduced 20 percent for the developed shoreline areas of the southwest and southeast basins, 
Table 20. Simulation 2: Limnological response to increased phosphorus and nitrogen loads caused by potential forest fires in watershed areas not burned during the 1994 forest fires

$\left[\mu \mathrm{g} / \mathrm{L}\right.$, micrograms per liter; $\mathrm{m}$, meters; $\left(\mathrm{mg} / \mathrm{m}^{3}\right) / \mathrm{d}$, milligrams per cubic meters per day;, , not measured]

\begin{tabular}{|c|c|c|c|c|c|c|c|c|c|c|}
\hline \multirow{2}{*}{$\begin{array}{l}\text { Segment } \\
\text { (fig. 3) }\end{array}$} & \multicolumn{2}{|c|}{$\begin{array}{c}\text { Total } \\
\text { phosphorus } \\
(\mu \mathrm{g} / \mathrm{L}) \\
\end{array}$} & \multicolumn{2}{|c|}{$\begin{array}{c}\text { Total } \\
\text { nitrogen } \\
(\mu \mathrm{g} / \mathrm{L}) \\
\end{array}$} & \multicolumn{2}{|c|}{$\begin{array}{c}\text { Chlorophyll-a } \\
(\mu \mathrm{g} / \mathrm{L}) \\
\end{array}$} & \multicolumn{2}{|c|}{$\begin{array}{c}\text { Secchi-disc } \\
\text { transparency } \\
(\mathbf{m}) \\
\end{array}$} & \multicolumn{2}{|c|}{$\begin{array}{l}\text { Hypolimnetic } \\
\text { dissolved- } \\
\text { oxygen } \\
\text { deficit } \\
{\left[\left(\mathrm{mg} / \mathrm{m}^{3}\right) \mathrm{d}\right]}\end{array}$} \\
\hline & 1996 & Response & 1996 & Response & $\overline{1996}$ & Response & 1996 & Response & 1996 & Response \\
\hline 1 & 7.3 & 10.1 & 319 & 607 & 1.3 & 1.9 & 5.2 & 4.8 & - & - \\
\hline 2 & 6.9 & 8.7 & 270 & 454 & 1.2 & 1.6 & 4.6 & 4.4 & - & - \\
\hline 3 & 6.4 & 8.6 & 276 & 493 & 1.1 & 1.6 & 4.8 & 4.5 & - & - \\
\hline 4 & 5.8 & 7.3 & 239 & 399 & 1.0 & 1.3 & 4.4 & 4.3 & 13.2 & 15.7 \\
\hline Lakewide & 6.4 & 8.4 & 270 & 476 & 1.1 & 1.5 & 4.7 & 4.5 & - & - \\
\hline
\end{tabular}

the McCall urban area, and the west shore of the peninsula. Sylvan, Dead Horse, and Fall Creeks were assigned nutrient reductions of 10 percent to simulate management of their developed shoreline areas. On a lakewide basis, concentrations of total phosphorus and total nitrogen declined from 6.5 to $6.4 \mu \mathrm{g} / \mathrm{L}$ and 127 to $125 \mu \mathrm{g} / \mathrm{L}$, respectively (table 21 ). Chlorophyll- $a$ and secchi-disc transparency were unchanged. The hypolimnetic dissolved-oxygen deficit in model segment 4 decreased about 1 percent. Small responses occurred in model segment 1 , the northern basin, because its volume is large and little of its shoreline is developed.

Model segment 4, the southwest basin, also has a large volume, but a substantial amount of its shoreline is developed. The responses of model segments 1 and 4 were similar because the effects of nutrient loads from devel- oped shoreline areas are minor in relation to the large volume of water in both of these lake basins.

Simulation 4 also used the responses from simulation 1 as the basis for assessing the lake's response to 20 -percent reductions in nutrient loads from watershed areas subjected to timber-harvest activities. Concentrations of total phosphorus, dissolved orthophosphorus, total nitrogen, and dissolved inorganic nitrogen were reduced 20 percent for the North Fork Payette River inflow; Box/Lemah Creeks; and Fall, Dead Horse, Copet, and Sylvan Creeks. On a lakewide basis, concentrations of total phosphorus, total nitrogen, and chlorophyll- $a$ decreased from 6.5 to $5.8 \mu \mathrm{g} / \mathrm{L}, 127$ to $108 \mu \mathrm{g} / \mathrm{L}$, and 1.1 to $1.0 \mu \mathrm{g} / \mathrm{L}$, respectively; secchi-disc transparency increased from 4.7 to $4.8 \mathrm{~m}$ (table 22). The hypolimnetic dissolved-oxygen deficit in model segment 4 decreased

Table 21. Simulation 3: Limnological response to 20-percent reduction in phosphorus and nitrogen loads from developed shoreline areas; comparison is to simulated response to pre-1994 forest fires (Simulation 1, table 19)

[ $\mu \mathrm{g} / \mathrm{L}$, micrograms per liter; $\mathrm{m}$, meters; $\left(\mathrm{mg} / \mathrm{m}^{3}\right) / \mathrm{d}$, milligrams per cubic meters per day; - , not measured]

\begin{tabular}{|c|c|c|c|c|c|c|c|c|c|c|}
\hline \multirow[b]{2}{*}{$\begin{array}{c}\text { Segment } \\
\text { (fig. 3) }\end{array}$} & \multicolumn{2}{|c|}{$\begin{array}{c}\text { Total } \\
\text { phosphorus } \\
(\mu g / L)\end{array}$} & \multicolumn{2}{|c|}{$\begin{array}{c}\text { Total } \\
\text { nitrogen } \\
(\mu \mathrm{g} / \mathrm{L})\end{array}$} & \multicolumn{2}{|c|}{$\begin{array}{c}\text { Chlorophyll-a } \\
(\mu g / L)\end{array}$} & \multicolumn{2}{|c|}{$\begin{array}{c}\text { Secchi-disc } \\
\text { transparency } \\
(\mathrm{m})\end{array}$} & \multicolumn{2}{|c|}{$\begin{array}{c}\text { Hypolimnetic } \\
\text { dissolved- } \\
\text { oxygen } \\
\text { deficit } \\
{\left[\left(\mathrm{mg} / \mathrm{m}^{3}\right) / \mathrm{d}\right]} \\
\end{array}$} \\
\hline & $\begin{array}{l}\text { Pre- } \\
\text { fire }\end{array}$ & Response & $\begin{array}{l}\text { Pre- } \\
\text { fire }\end{array}$ & Response & $\begin{array}{l}\text { Pre- } \\
\text { fire }\end{array}$ & Response & $\begin{array}{l}\text { Pre- } \\
\text { fire }\end{array}$ & Response & $\begin{array}{l}\text { Pre- } \\
\text { fire }\end{array}$ & Response \\
\hline 1 & 7.1 & 7.0 & 138 & 136 & 1.2 & 1.2 & 5.2 & 5.2 & - & - \\
\hline 2 & 7.1 & 6.9 & 129 & 127 & 1.3 & 1.2 & 4.6 & 4.6 & - & - \\
\hline 3 & 6.5 & 6.4 & 128 & 126 & 1.1 & 1.1 & 4.8 & 4.8 & - & - \\
\hline 4 & 6.1 & 5.9 & 120 & 118 & 1.0 & 1.0 & 4.4 & 4.4 & 13.3 & 13.2 \\
\hline Lakewide & 6.5 & 6.4 & 127 & 125 & 1.1 & 1.1 & 4.7 & 4.7 & - & - \\
\hline
\end{tabular}


Table 22. Simulation 4: Limnological response to 20-percent reduction in phosphorus and nitrogen loads from watershed areas subjected to timber-harvest activities; comparison is to simulated response to pre1994 forest fires (Simulation 1, table 19)

$\left[\mu \mathrm{g} / \mathrm{L}\right.$, micrograms per liter; $\mathrm{m}$, meters; $\left(\mathrm{mg} / \mathrm{m}^{3}\right) / \mathrm{d}$, milligrams per cubic meters per day; - , not measured]

\begin{tabular}{|c|c|c|c|c|c|c|c|c|c|c|}
\hline \multirow[b]{2}{*}{$\begin{array}{c}\text { Segment } \\
\text { (fig. 3) }\end{array}$} & \multicolumn{2}{|c|}{$\begin{array}{c}\begin{array}{c}\text { Total } \\
\text { phosphorus } \\
(\mu g / L)\end{array} \\
\end{array}$} & \multicolumn{2}{|c|}{$\begin{array}{c}\text { Total } \\
\text { nitrogen } \\
(\mu g / L)\end{array}$} & \multicolumn{2}{|c|}{$\begin{array}{c}\text { Chlorophyll-a } \\
(\mu g / L)\end{array}$} & \multicolumn{2}{|c|}{$\begin{array}{c}\text { Secchi-disc } \\
\text { transparency } \\
(\mathrm{m}) \\
\end{array}$} & \multicolumn{2}{|c|}{$\begin{array}{c}\text { Hypolimnetic } \\
\text { dissolved- } \\
\text { oxygen } \\
\text { deficit } \\
{\left[\left(\mathrm{mg} / \mathrm{m}^{3}\right) / \mathrm{d}\right]}\end{array}$} \\
\hline & $\begin{array}{l}\text { Pre- } \\
\text { fire }\end{array}$ & Response & $\begin{array}{l}\text { Pre- } \\
\text { fire }\end{array}$ & Response & $\begin{array}{l}\text { Pre- } \\
\text { fire }\end{array}$ & Response & $\begin{array}{l}\text { Pre- } \\
\text { fire }\end{array}$ & Response & $\begin{array}{l}\text { Pre- } \\
\text { fire }\end{array}$ & Response \\
\hline 1 & 7.1 & 6.1 & 138 & 115 & 1.2 & 1.0 & 5.2 & 5.4 & - & - \\
\hline 2 & 7.1 & 6.4 & 129 & 111 & 1.3 & 1.1 & 4.6 & 4.7 & - & - \\
\hline 3 & 6.5 & 5.7 & 128 & 109 & 1.1 & .9 & 4.8 & 4.9 & - & - \\
\hline 4 & 6.1 & 5.5 & 120 & 104 & 1.0 & .9 & 4.4 & 4.4 & 13.3 & 12.3 \\
\hline Lakewide & 6.5 & 5.8 & 127 & 108 & 1.1 & 1.0 & 4.7 & 4.8 & - & - \\
\hline
\end{tabular}

about 8 percent. The largest percentage responses were in model segment 1 because most of the nutrient load reductions occurred in its tributary watersheds. The smallest percentage responses were in model segment 4 because its tributary watersheds were unaffected in this simulation.

Simulation 5 combined the nutrient load reductions applied in simulations 3 and 4 . On a lakewide basis, concentrations of total phosphorus, total nitrogen, and chlorophyll- $a$ declined from 6.5 to $5.7 \mu \mathrm{g} / \mathrm{L}, 127$ to $108 \mu \mathrm{g} / \mathrm{L}$, and 1.1 to $0.9 \mu \mathrm{g} / \mathrm{L}$, respectively; secchi-disc transparency increased from 4.7 to $4.8 \mathrm{~m}$ (table 23). The hypolimnetic dissolved-oxygen deficit in model segment 4 decreased about 8.5 percent. Of the three nutri- ent reduction simulations, this one achieved the largest responses lakewide and in each of the four model segments.

\section{SUMMARY AND CONCLUSIONS}

Hydrologic inputs during 1995-96 were larger than the long-term mean and, thereby, reduced the residence time of water in Payette Lake by 22 percent in 1995 and 40 percent in 1996. Loads of nitrogen and phosphorus delivered to the lake were increased by the larger flows and by the effects of the 1994 forest fires that burned about one-half of the lake's watershed. The

Table 23. Simulation 5: Limnological response to 20-percent reduction in phosphorus and nitrogen loads from developed shoreline areas and watershed areas subjected to timber-harvest activities; comparison is to simulated response to pre-1994 forest fires (Simulation 1, table 19)

[ $\mu \mathrm{g} / \mathrm{L}$, micrograms per liter; $\mathrm{m}$, meters; $\left(\mathrm{mg} / \mathrm{m}^{3}\right) / \mathrm{d}$, milligrams per cubic meters per day; - , not measured]

\begin{tabular}{|c|c|c|c|c|c|c|c|c|c|c|}
\hline \multirow[b]{2}{*}{$\begin{array}{c}\text { Segment } \\
\text { (fig. 3) }\end{array}$} & \multicolumn{2}{|c|}{$\begin{array}{c}\text { Total } \\
\text { phosphorus } \\
(\mu \mathrm{g} / \mathrm{L})\end{array}$} & \multicolumn{2}{|c|}{$\begin{array}{c}\begin{array}{c}\text { Total } \\
\text { nitrogen } \\
(\mu g / L)\end{array} \\
\end{array}$} & \multicolumn{2}{|c|}{$\begin{array}{c}\text { Chlorophyll-a } \\
(\mu g / L)\end{array}$} & \multicolumn{2}{|c|}{$\begin{array}{c}\begin{array}{c}\text { Secchi-disc } \\
\text { transparency } \\
(\mathrm{m})\end{array} \\
\end{array}$} & \multicolumn{2}{|c|}{$\begin{array}{c}\text { Hypolimnetic } \\
\text { dissolved- } \\
\text { oxygen } \\
\text { deficit } \\
{\left[\left(\mathrm{mg}^{\mathrm{m}} \mathrm{m}^{3}\right) / \mathrm{d}\right]} \\
\end{array}$} \\
\hline & $\begin{array}{l}\text { Pre- } \\
\text { fire }\end{array}$ & Response & $\begin{array}{l}\text { Pre- } \\
\text { fire }\end{array}$ & Response & $\begin{array}{l}\text { Pre- } \\
\text { fire }\end{array}$ & Response & $\begin{array}{l}\text { Pre- } \\
\text { fire }\end{array}$ & Response & $\begin{array}{l}\text { Pre- } \\
\text { fire }\end{array}$ & Response \\
\hline 1 & 7.1 & 6.1 & 138 & 114 & 1.2 & 1.0 & 5.2 & 5.4 & - & - \\
\hline 2 & 7.1 & 6.2 & 129 & 110 & 1.3 & 1.1 & 4.6 & 4.7 & - & - \\
\hline 3 & 6.5 & 5.7 & 128 & 108 & 1.1 & .9 & 4.8 & 4.9 & - & - \\
\hline 4 & 6.1 & 5.4 & 120 & 104 & 1.0 & .9 & 4.4 & 4.5 & 13.3 & 12.2 \\
\hline Lakewide & 6.5 & 5.7 & 127 & 108 & 1.1 & .9 & 4.7 & 4.8 & - & - \\
\hline
\end{tabular}


percentage contribution of nutrient loads from the lake's primary tributary, the North Fork Payette River, during 1995-96 averaged 28.2 percent for phosphorus and 70 percent for nitrogen. On the basis of two earlier studies of nutrient loads to Payette Lake, these two percentages indicate a decrease in the influence of the primary tributary on phosphorus loads and an increase in the relative contribution from nearshore areas and smaller tributaries draining directly to the lake. A similar conclusion would have been reached for nitrogen if the forest fires had not increased nitrogen loads about fivefold.

Payette Lake was oligotrophic during 1995-96, on the basis of concentrations of total nitrogen, total phosphorus, and chlorophyll- $a$. The forest fires increased concentrations of total and dissolved nitrogen throughout the lake; no such increases were apparent for phosphorus. Because the lake's phytoplankton productivity is strongly limited by phosphorus, the large increase in dissolved inorganic nitrogen did not dramatically increase chlorophyll- $a$ concentrations. Increases in chlorophyll- $a$ concentrations were only about twofold compared with those measured 2 years prior to the 1994 forest fires. Despite its oligotrophy, Payette Lake did develop anoxia in the lower hypolimnion of the southwest basin for about 4 months in each year. Substantial hypolimnetic-oxygen depletion also was measured in this basin under winter ice cover in February 1996. Low dissolved-oxygen concentrations in the southwest basin were measured in 1981 and 1992-93; thus, they are not a byproduct of the 1994 forest fires.

The hypolimnetic dissolved-oxygen deficit in Payette Lake was much larger than was predicted by the nutrient load/lake response model's empirical relation of hypolimnetic dissolved-oxygen deficit with nutrient and chlorophyll- $a$ concentrations. Payette Lake's propensity for developing a substantial hypolimnetic dissolved-oxygen deficit is rooted in several factors, not all of which are anthropogenic. Long-term human development of the watershed and the nearshore area produced small, but cumulative, increases in the lake's nutrient budget and, consequently, increased the lake's biological productivity as documented in the 1975 and 1981-82 studies that concluded the lake was mesotrophic, or moderately enriched. The increased biological production from phytoplankton and periphyton generated additional organic matter. The organic matter that is not flushed out of the lake settles through the water column, exerts an oxygen demand while settling, and eventually is deposited onto the lakebed sediments. The lakebed sediments in the southwest basin contained much more phosphorus than the other three basins contained. Therefore, most of the oxygen-demanding organic matter was produced in or advectively transported to the southwest basin because its shoreline is the most developed and it is the terminal basin in the lake.

Several natural factors influence the development of the hypolimnetic dissolved-oxygen deficit. The long water-residence time, as determined by lake volume and outflow volume, facilitates water-column retention of the oxygen-demanding organic matter produced within the lake or delivered from terrestrial sources. The lake's depth, especially in the southwest and northern basins, retards water-column circulation and consequent reaeration of the hypolimnion into December despite the loss of thermal stratification a month or two earlier. The delay in hypolimnetic reaeration extends the time over which organic matter exerts an oxygen demand on the hypolimnetic oxygen supply. That oxygen supply is finite in that it is delivered during the spring water-column circulation and is not replenished if thermal stratification persists over the summer. At station 1, the lack of complete reaeration during spring water-column circulation exacerbates the hypolimnetic dissolved-oxygen deficit problem because the southwest basin begins the thermal stratification period with an incomplete supply of dissolved oxygen with which to satisfy its hypolimnetic oxygen demands.

Although oligotrophic, the lake accumulates organic matter in its lakebed sediments. When the oxygen supply becomes exhausted at the sediment-water interface, as it was at station 1 from September into December of 1995 and 1996, redox conditions can develop that allow release of nutrients from the sediments into the overlying water column. Such releases were detected in 1995 but not in 1996. If anoxia became a persistent feature in Payette Lake and extended upward into the hypolimnion, then the release of sediment-bound nutrients would constitute an additional, internal load of nutrients that would fuel biological production.

The question implied by the title of this report, "Eutrophication potential of Payette Lake, Idaho," should perhaps be restated as, "Can eutrophication of Payette Lake be reversed?" The substantial hypolimnetic dissolved-oxygen deficits and development of anoxia constitute strong symptomatic evidence that Payette Lake has undergone eutrophication despite its oligotrophic classification. The lengthy water-residence time and incomplete water-column circulation in the spring and autumn have prevented the lake from discharging some of its annual biological production. Consequently, 
a long-term buildup of nutrients and oxygen-demanding substances in the lakebed sediments, coupled with the lake's biological production, has been large enough to create hypolimnetic dissolved-oxygen deficits and, in some years, anoxia. The calibration and simulations used in the nutrient load/lake response model indicated that the hypolimnetic dissolved-oxygen deficit was relatively insensitive to moderate, and realistic, reductions in nutrient loads to the lake. Such insensitivity is due, in part, to the strong limitation of phytoplankton production by phosphorus. Given this insensitivity and low concentrations of phosphorus in the lake, the annual development of hypolimnetic dissolved-oxygen deficits may be expected to continue, despite reductions of nutrient loads from watershed and nearshore sources.

Conversely, an important water-quality management goal may be to prevent increases in phosphorus loads to Payette Lake, given the strong limitation by phosphorus of phytoplankton production.

\section{REFERENCES CITED}

Ahlgren, I.F., and Ahlgren, C.E., 1960, Ecological effects of forest fire: Botanical Review, v. 26, p. 483-533.

Brennan, T.S., Lehmann, A.K., O'Dell, I., and Tungate, A.M., 1996, Water resources data, Idaho, water year 1995, v. 2, Upper Columbia River Basin and Snake River Basin below King Hill: U.S. Geological Survey Water-Data Report ID-95-2, $357 \mathrm{p}$.

-1997, Water resources data, Idaho, water year 1996, v. 2, Upper Columbia River Basin and Snake River Basin below King Hill: U.S. Geological Survey WaterData Report ID-96-2, 377 p.

Britton, L.J., and Greeson, P.E., eds., 1989, Methods for collection and analysis of aquatic biological and microbiological samples: U.S. Geological Survey Techniques of Water Resources Investigations, book 5, chap. A4, $363 \mathrm{p}$.

Brown, R.G., 1987, Errors in estimating ground-water components of hydrologic and phosphorus budgets of lakes, in Selected Papers in the Hydrologic Sciences: U.S. Geological Survey Water-Supply Paper 2310-D, p. 53-64.

Buchanan, T.J., and Somers, W.P., 1968, Stage measurements at gaging stations: U.S. Geological Survey Techniques of Water Resources Investigations, book 3, chap. A7, $28 \mathrm{p}$.

1969, Discharge measurements at gaging stations: U.S. Geological Survey Techniques of Water Resources Investigations, book 3, chap. A8, $65 \mathrm{p}$.
Carter, R.W., and Davidian, J., 1968, General procedures for gaging streams: U.S. Geological Survey Techniques of Water Resources Investigations, book 3, chap. A6, 13 p.

Edwards, T.K., and Glysson, G.D., 1988, Field methods for measurement of fluvial sediment: U.S. Geological Survey Open-File Report 86-531, 118 p.

Falter, C.M., 1984, Nutrient and bacterial loading to Big Payette Lake, Valley County, Idaho, 1982: Moscow, University of Idaho, $55 \mathrm{p}$.

Falter, C.M., and Mitchell, B.D., 1981, Limnology of Payette Lake with reference to sewer pipe line construction: Moscow, University of Idaho, $41 \mathrm{p}$.

Fischer, H.B., List, E.J., Koh, R.C.Y., Imberger, Jorg, and Brooks, N.H., 1979, Mixing in inland and coastal waters: New York, Academic Press, 483 p.

Fishman, M.J., and Friedman, L.C., eds., 1989, Methods for determination of inorganic substances in water and fluvial sediments: U.S. Geological Survey Techniques of Water Resources Investigations, book 5, chap. Al, $545 \mathrm{p}$.

Friedman, L.C., and Erdmann, D.E., 1982, Quality assurance practices for the chemical and biological analyses of water and fluvial sediments: U.S. Geological Survey Techniques of Water Resources Investigations, book 5, chap. A6, $181 \mathrm{p}$.

Grier, C.C., 1975, Wildfire effects on nutrient distribution and leaching in a coniferous ecosystem: Canadian Journal of Forest Research, v. 5, p. 599-607.

Helsel, D.R., and Hirsch, R.M., 1992, Statistical methods in water resources: Amsterdam, The Netherlands, Elsevier Science Publishers, $529 \mathrm{p}$.

Helvey, J.D., Tiedemann, A.R., and Anderson, T.D., 1985, Plant nutrient losses by soil erosion and mass movement after wildfire: Journal of Soil and Water Conservation, v. 40 , no. 1 , p. $168-173$.

Hem, J.P., 1985, Study and interpretation of the chemical characteristics of natural water ( $3 d$ ed.): U.S. Geological Survey Water-Supply Paper 2254, $264 \mathrm{p}$.

Hutchinson, G.E., 1957, A treatise on limnology-volume 1, geography, physics, and chemistry: New York, John Wiley and Sons, Inc., $1015 \mathrm{p}$.

Idaho Department of Health, 1970, Payette Lakes, a water quality study, 1967-1969: Boise, Idaho, 9 p. plus appendices.

Kennedy, E.J., 1983, Computation of continuous records of streamflow: U.S. Geological Survey Techniques of Water Resources Investigations, book 3, chap. A13, $53 \mathrm{p}$.

1984, Discharge ratings at gaging stations: U.S. Geological Survey Techniques of Water Resources Investigations, book 3, chap. A10, $59 \mathrm{p}$.

Koenings, J.P., Kyle, G.B., Edmundson, J.A., and Edmundson, J.M., 1987, Limnology field and laboratory manualmethods for assessing aquatic production: Juneau, 
Alaska Department of Fish and Game, Division of Fisheries Rehabilitation, Enhancement, and Development, Report no. 71, 212 p.

Persaud, D., Jaagumagi, R., and Hayton, A., 1993, Guidelines for the protection and management of aquatic sediment quality in Ontario: Ontario Ministry of Environment and Energy, $24 \mathrm{p}$.

Prescott, G.W., 1969, How to know the aquatic plants: Dubuque, Iowa, Wm. C. Brown Company Publishers, $171 \mathrm{p}$.

1970, How to know the freshwater algae: Dubuque, Iowa, Wm. C. Brown Company Publishers, 348 p.

Pritt, J.W., and Raese, J.W., eds., 1995, Quality assurance/ quality control manual, National Water Quality Laboratory: U.S. Geological Survey Open-File Report 95-443, $35 \mathrm{p}$.

Riggs, H.C., 1968, Some statistical tools in hydrology: U.S. Geological Survey Techniques of Water Resources Investigations, book 4, chap. A1, 39 p.

Rothrock, G.C., and Mosier, D.T., 1996, Phase 1 diagnostic analysis, Priest Lake, Bonner County, Idaho, 1993-1995: Boise, Idaho Department of Health and Welfare, Division of Environmental Quality, $191 \mathrm{p}$.

Ryding, S.O., and Rast, Walter, 1989, Control of eutrophication at lakes and reservoirs, v. 1 of Programme on man and the biosphere series: Cambridge University Press, $295 \mathrm{p}$.

Schindler, D.W., Newbury, R.W., Beaty, K.G., Prokopowich, J., Ruszczynski, T., and Dalton, J.A., 1980, Effects of a windstorm and forest fire on chemical losses from forested watersheds and on the quality of receiving streams: Canadian Journal of Fisheries and Aquatic Science, v. 37 , p. $328-334$.

Schueler, T.R., 1987, Controlling urban runoff-a practical manual for planning and designing urban BMP's: Washington, D.C., Metropolitan Washington Council of Governors, not paged.

Schuldt, J.A., and Hershey, A.E., 1995, Effect of salmon carcass decomposition on Lake Superior tributary streams: Journal of the North American Benthological Society, v. 14 , no. 2 , p. $259-268$.
Steward, A.N., Dennis, L.J., and Gilkey, H.M., 1963, Aquatic plants of the Pacific Northwest: Corvallis, Oregon State University Press, $261 \mathrm{p}$.

Stumm, Werner, and Morgan, J.J., 1970, Aquatic chemistry; an introduction emphasizing chemical equilibria in natural waters: New York, John Wiley and Sons, Inc., $583 \mathrm{p}$.

Tiedemann, A.R., 1981, Stream chemistry, nutrient economy, and site productivity consequences of wildland management and wildfire, in Baumgartner, D.M., ed., Symposium on Interior West Watershed Management: Pullman, Washington State University Cooperative Extension Service, p. 184-201.

Tiedemann, A.R., Conrad, C.E., Dieterich, J.H., Hornbeck, J.W., Megahan, W.F., Viereck, L.A., and Wade, D.D., 1979, Effects of fire on water-a state-of-knowledge review: Washington, D.C., U.S. Forest Service General Technical Report WO-10, 28 p.

U.S. Environmental Protection Agency, 1977, Report on Payette Lake, Valley County, Idaho: Washington, D.C., U.S. Environmental Protection Agency, National Eutrophication Survey Working Paper no. 784, 17 p., 5 apps.

U.S. Forest Service, 1995a, Blackwell post-fire landscape assessment working draft, February 15, 1995: McCall, Idaho, Payette National Forest [variously paged]. 1995b, North Fork Payette post-fire projectenvironmental assessment: McCall, Idaho, Payette National Forest [variously paged].

Valley County, 1995, Valley County comprehensive plan: Cascade, Idaho, Valley County Courthouse, 58 p.

Walker, W.W., 1996, Simplified procedures for eutrophication assessment and prediction-user manual: U.S. Army Corps of Engineers, Waterways Experiment Station, Instruction Report W-96-2 [variously paged].

Welch, E.B., 1980, Ecological effects of waste water, with a section on Hydrographic characteristics, by $\mathrm{T}$. Lindell: Cambridge University Press, $337 \mathrm{p}$.

Winter, T.C., 1981, Uncertainties in estimating the water balance of lakes: Water Resources Bulletin, v. 17, no. 1, p. $82-115$. 